\title{
Effects of Acid Mine Drainage and Acid Precipitation on Leaf Litter Breakdown Rates in Appalachian Headwater Streams
}

\author{
Mary Fiona Stewart \\ West Virginia University
}

Follow this and additional works at: https://researchrepository.wvu.edu/etd

\section{Recommended Citation}

Stewart, Mary Fiona, "Effects of Acid Mine Drainage and Acid Precipitation on Leaf Litter Breakdown Rates in Appalachian Headwater Streams" (2010). Graduate Theses, Dissertations, and Problem Reports. 3068.

https://researchrepository.wvu.edu/etd/3068

This Thesis is protected by copyright and/or related rights. It has been brought to you by the The Research Repository @ WVU with permission from the rights-holder(s). You are free to use this Thesis in any way that is permitted by the copyright and related rights legislation that applies to your use. For other uses you must obtain permission from the rights-holder(s) directly, unless additional rights are indicated by a Creative Commons license in the record and/ or on the work itself. This Thesis has been accepted for inclusion in WVU Graduate Theses, Dissertations, and Problem Reports collection by an authorized administrator of The Research Repository @ WVU. For more information, please contact researchrepository@mail.wvu.edu. 


\author{
Mary Fiona Stewart
}

\author{
A Thesis submitted to the \\ Davis College of Agriculture, Natural Resources and Design \\ at West Virginia University \\ in partial fulfillment of the requirements \\ for the degree of \\ Master of Science \\ in \\ Wildlife and Fisheries Resources
}

\author{
J. Todd Petty, Ph.D., Chair \\ George T. Merovich, Ph.D. \\ Dorothy J. Vesper, Ph.D.
}

Wildlife and Fisheries Resources Program
Division of forestry and Natural Resources

Morgantown, WV

2010

Keywords: Decomposition, Leaf Breakdown, Ecosystem Function, Acid Mine Drainage, Acid Precipitation, Shredder Composition, Microbial Activity 


\section{Abstract \\ Effects of Acid Mine Drainage and Acid Precipitation on Leaf Litter Breakdown Rates in Appalachian Headwater Streams}

\section{Mary Fiona Stewart}

Acid precipitation and acid mine drainage have dramatically altered chemical conditions and biological assemblages in streams throughout the central Appalachians. Effects of acidification on functional stream processes such as organic matter decomposition, however, remain poorly understood. The objectives of this study were to: 1- quantify differences in organic matter decomposition among reference streams, streams impacted by acid precipitation, and streams impacted by acid mine drainage; and 2- determine if lowered decomposition rates are the result of reduced microbial activity or altered invertebrate shredder assemblages or both. I quantified water chemistry, organic matter decomposition, microbial activity, and macroinvertebrate community structure in 15 headwater streams in the central Appalachian ecoregion ( 5 circumneutral reference, 5 acid mine drainage, and 5 acid precipitation). Decomposition rates were quantified from leaf packs deployed for a period of 120 days over three seasons. Water chemistry was sampled in conjunction with decomposition trials. Benthic invertebrate communities were sampled in spring and fall. Microbial activity was measured as total microbial community respiration and ergosterol content. Acid mine drainage resulted in dramatically reduced shredder assemblages, reduced microbial activity and reduced overall organic matter decomposition. Acid precipitation resulted in altered shredder assemblages, reduced microbial respiration and diminished organic matter decomposition, but not as severely as seen in acid mine drainage streams. Overall, decomposition rates were more strongly correlated with microbial respiration and ergosterol concentration than shredder community composition. However, shifts in shredder assemblages, including the loss of acid sensitive voracious shredders, such as Lepidosotoma, Limnephilidae, Petronarcys, Gammarus, and Decopoda, also is likely responsible for the reduction in organic matter processing ability in acid impacted streams. Our results provide further evidence that restoration of acidic headwater Appalachian streams is needed in order to effectively manage conditions in larger aquatic ecosystems downstream. 


\section{Table of Contents}

List of Tables.........................................................................................................................iv

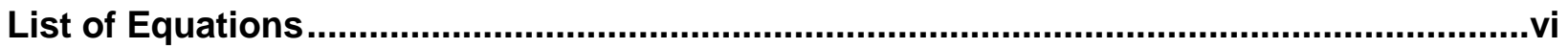

List of Figures ..........................................................................................................................

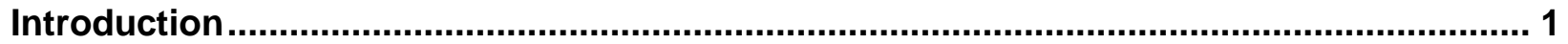

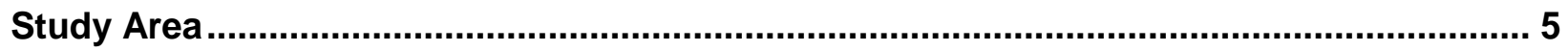

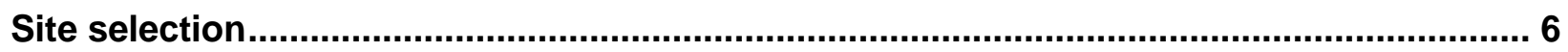

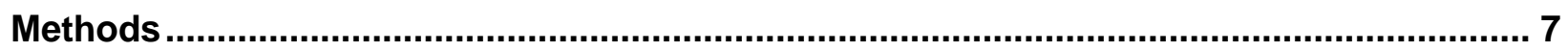

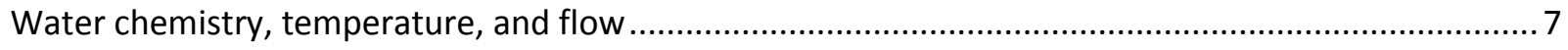

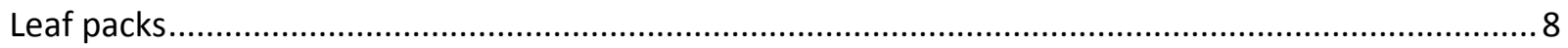

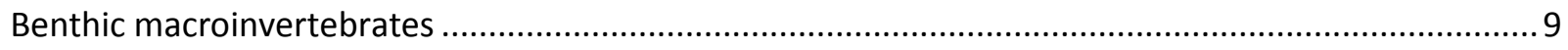

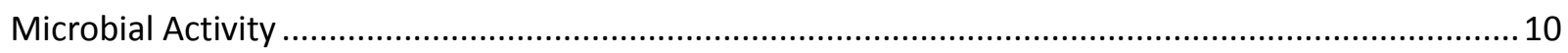

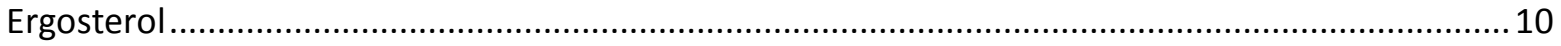

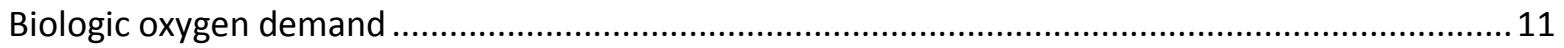

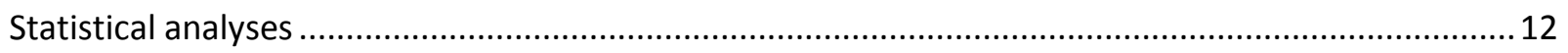

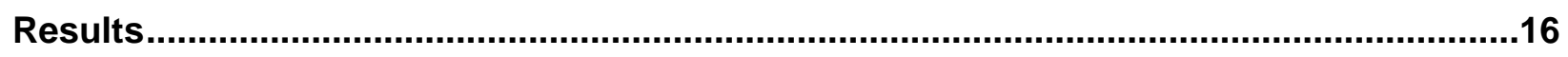

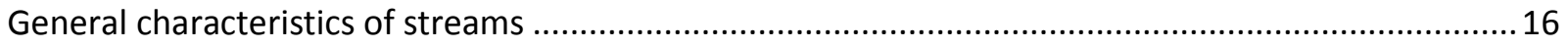

Drainage area, discharge, temperature and slope ....................................................................... 16

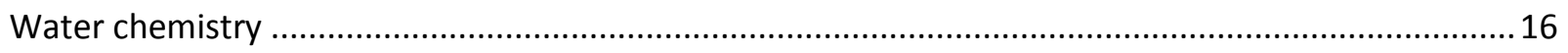

PCA …

Differences in water chemistry among stream types ................................................................. 17

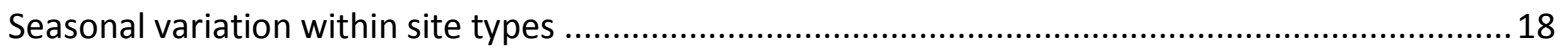

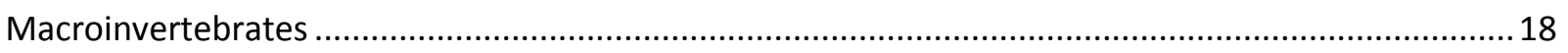

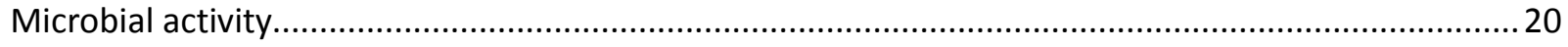

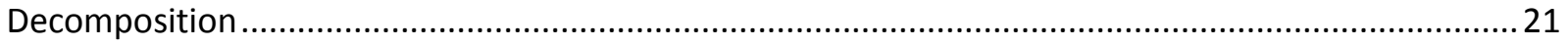

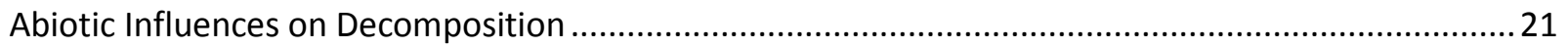

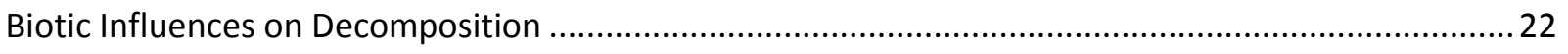

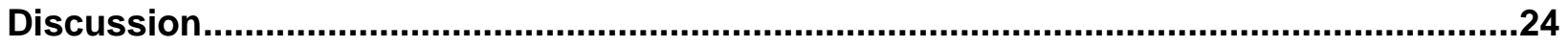

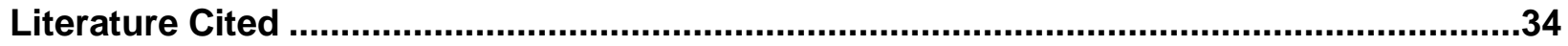

Appendix I. Average number of individuals, percentage of assemblage and percentage of functional feeding group for each genus collected for each site type................................83 


\section{List of Tables}

Table 1: Classifications of some distinguishing water chemistry parameters

Table 2: Location, acid contaminating type, and general characteristics of 15 study streams....45

Table 3: Mean ( \pm SE) drainage area, annual average discharge, slope, and annual average stream temperature for each stream type.

Table 4: Principle components analysis (PCA) results from average water chemistry over three seasons (summer, winter, and spring) of decomposition.....

Table 5: Mean ( \pm SE) water chemistry parameters by site type for the summer decomposition trial.

Table 6: Mean $( \pm S E)$ water chemistry parameters by site type for the winter decomposition trial.

Table 7: Mean ( \pm SE) water chemistry parameters by site type for the spring decomposition trial.

Table 8: Annual average water chemistry parameters by stream type across three seasonal sampling periods.

Table 9: Relationship of water chemistry variables and macroinvertebrate metrics to nonmetric multidimensional scaling (NMDS) ordination of macroinvertebrate genera in 2 dimensions by vector fitting

Table 10: Mean ( \pm SE) invertebrate metrics for each stream type .53

Table 11: Results from an analysis of similarity (ANOSIM) including all pairwise comparisons of shredder assemblage among the stream types.... 
Table 12: Mean $( \pm S E)$ number of total shredders and number of shredders from different taxa for each stream type

Table 13: Mean ( \pm SE) measures of microbial activity by site type. .56

Table 14: F-values from repeated measures ANOVA of the remaining leaf mass from each seasonal decomposition trial.

Table 15: Seasonal and annual mean ( \pm SE) decomposition rates for each stream.

Table 16: Mean ( \pm SE) decomposition rates for each stream type.

Table 17: Results of a two way ANOVA between site type and season to determine if season had an influence on decomposition rate.

Table 18: Results of ANCOVAs to determine if physical stream parameters influenced decomposition rates.

Table 19: Results of ANCOVAs to determine if total number of shredders or number of shredders from different taxa influenced decomposition rates.

Table 20: Correlation of family level macroinvertebrate metrics with annual average decomposition rate.

Table 21: Results of ANCOVA used to determine which microbial variables influenced annual average decomposition rates.

Table 22: Models created from likely shredder, microbial and physical parameters and ranked by Akaike Information Criterion. 


\section{List of Equations}

Equation 1: Most likely model to predict leaf litter decomposition rate as ranked by Akaike

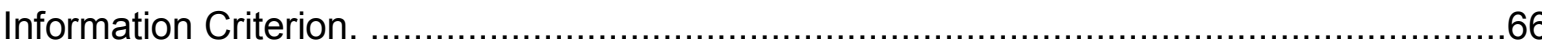

Equation 2: Second most likely model to predict leaf litter decomposition rate as ranked by

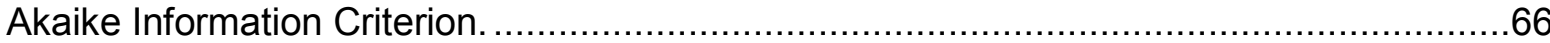




\section{List of Figures}

Figure 1: Hierarchical framework of factors controlling rates of leaf processing in streams, showing the abiotic and biotic interactions influencing leaf processing according to their levels of influence.

Figure 2: Bedrock geology of Muddy Creek and the Big Sandy Creek watersheds. .68

Figure 3: Surface mines and abandoned mines in the muddy Creek and Big Sandy Creek watersheds

Figure 4: Location of study sites

Figure 5: Bivariate scatter plot of principle component (PC) 1 and 2 scores of averaged water chemistry samples for each seasonal decomposition trial for each stream; summer $(A)$, winter (B), spring (C).

Figure 6: Bivariate scatter plot of the annual mean ( \pm SE) principal component (PC) 1 and 2 scores of water chemistry samples for each stream.

Figure 7: nonmetric multidimensional scale of macroinvertebrate communities collected at each stream (A). An environmental fit of the associated water chemistry variables are shown in $B$, and an environmental fit of the associated macroinvertebrate metrics are shown in C...73

Figure 8: Cluster analysis of shredder community assemblages

Figure 9: Mean $( \pm S E)$ number of individuals from a taxon contributing to the shredder functional feeding group for each stream type....

Figure 10: Mean $( \pm S E)$ remaining leaf mass for each stream types for every decomposition trial; summer $(A)$, winter $(B)$, and spring $(C)$.

Figure 11: Mean (+SE) decomposition rate of oak leaves in circumneutral $(\mathrm{CN})$, acid precipitation (AP) and acid mine drainage (AMD) streams 
Figure 12: Annual average decomposition rates of each study stream organized by stream type

Figure 13: Relationship between the annual average decomposition rate and drainage area (A), annual average stream temperature $(B)$, annual average stream discharge $(C)$, and percent slope (D)

Figure 14: Relationship between annual average decomposition rates and total shredder abundance (A),shredder richness (B), number of shredding Trichoptera (C), number of shredding Plecoptera (D), number of shredding Tipulidae (E), and number of Nemouridae (F)

Figure 15: Relationships between annual average decomposition rate and microbial respiration rate $(A$ and $B)$ and ergosterol concentration $(C$ and $D)$ 


\section{Introduction}

Ecological integrity of natural ecosystems can be subdivided into two components: structural and functional, with structure determining function and function in turn affecting structure (Gessener and Chauvet 2002). However, structure and function describe different aspects of the same entity; consequently both must be considered if the integrity of an ecosystem as a whole is to be addressed (Gessener and Chauvet 2002). There are three responses that an ecosystem can have to stressors. The first is a structural change without modification to functional processes. The second is a functional change without a modification to community structure. The third is a change in both structure and function (Gessener and Chauvet 2002, Dangles et al. 2004).

Invertebrate metrics are the common method of assessing stream ecosystem integrity; however, they contribute little to an understanding of how an ecosystem functions and therefore should not be the sole consideration (Bunn et al. 1999, Dangles et al. 2004). Studies have found large variation in functional processes between streams that fall into the same category within an invertebrate metric (Bunn and Davies 2000), indicating that biological processes may provide a more integrative measure of ecosystem integrity (Gessener and Chauvet 2002). However, it is essential to determine which ecosystem processes respond to anthropogenic stressors, and therefore which processes may be good indicators of functional degradation (Dangles et al. 2004).

Leaf litter breakdown rate has proven to be sensitive to changes in the stream environment (Wallace et al. 1996, Pascoal et al. 2001). Measuring leaf litter breakdown rate has several advantages as a functional indicator. For example, organic matter processing reflects the total energetic processing of a stream ecosystem, giving information on the 
abundance and activity of microbial communities, illustrating the structure and efficiency of macroinvertebrates in particular shredders, and providing information on physical and chemical features of the stream (Pascoal et al. 2003, Braioni et al. 2004, Dangles et al. 2004, and Simon et al. 2009).

Detritus in the form of fallen leaves is a vital resource for most aquatic ecosystems (Hutchens and Wallace 2002), particularly woodland streams, since they receive more energy from outside inputs than are produced from within (Suberkropp and Chauvet 1995, Dangles and Guerold 2001). Because riparian leaves dominate allochthonous inputs, they are the major source of energy for heterotrophic organisms (Webster et al. 1999). In a functional stream, detritus upon entering should be retained and biophysically transformed through consumption and feeding processes (Wipfli et al. 2007). The presence and quantity of detritovores will control the rate of both nutrients and dissolved organic matter released into the water column (Wallace et al. 1996). Therefore, leaf litter breakdown, where large particles are broken down to smaller particles that can be consumed by a second functional feeding group, plays a critical role in the stream food web (Gessener and Chauvet 2002, Schlief and Mutz 2006). Due to their high retentive capacity (Webster et al. 1999), headwater streams are particularly crucial in the leaf litter breakdown process and the export of nutrients and dissolved organic matter to downstream systems (Wipfli et al. 2007). Because the breakdown of leaves is an essential process of energy flux in the food webs of streams, any alteration to the process, especially in headwater streams, may have a large effect on the whole stream community, both locally and downstream (Simon et al. 2009).

The breakdown of leaves is achieved in three phases: leaching, conditioning and fragmenting (Barnden and Harding 2005). Chemical leaching of dissolved materials from leaves is the initial process and can account for up to a $30 \%$ of mass loss (Webster et al. 1999). However, leaching alone will not lead to physical leaf breakdown. Physical breakdown occurs 
only after detritus has been softened by microbial action (Webster et al. 1999). In the second stage of leaf breakdown, leaves are colonized by microorganisms and conditioned through chemical changes brought about by enzymatic activity (Schliet 2004, Schlief and Mutz 2006), which begins the decomposition process and increases the palatability of leaves for detritivorous macroinvertebrates (Barnden and Harding 2005). The third stage, fragmentation, is predominantly driven by the feeding activity of macroinvertebrates, which are capable of consuming leaf material only after microbial softening (Webster et al. 1999, Schlief and Mutz 2006). The capacity of each one of these stages can be influenced by abiotic factors such as stream temperature, discharge, water chemistry and presence of pollutants (Figure 1) (Pascoal et al. 2001, Simon et al. 2009).

Freshwater ecosystems can be stressed by a broad range of anthropogenic impacts (Pascoal et al 2001). Biological systems in streams may be altered through modifications of physical habitat, hydrology, water chemistry, and food web structure (Karr 1999). Any one of these stressors may influence the structure and function of benthic communities as well as processes such as leaf litter breakdown (Pascoal et al. 2001). However, different components of an ecosystem are expected to respond to stressors to different degrees (Fisher et al. 1998). It is recognized that macroinvertebrate communities differ in sensitivity to various types of pollutants and have a graded response (Pascoal et al. 2001). Shredder mediated leaf litter breakdown may be affected by stressors since food resource may be altered through changes in food palatability. Shredder abundance may be reduced or shredder species composition may be shifted (Dangles and Guerold 2001). Stress may also alter the role of microorganisms on leaf litter breakdown in polluted streams (Pascoal et al. 2001).

Acid deposition has degraded numerous freshwater ecosystems, and despite reductions in sulfate emissions, stream acidification persists as a common problem (McClurg et al. 2007, Simon et al. 2009). Acidification related damage of freshwater systems includes reduced 
diversity and altered assemblages of algae, amphibians, invertebrates and fishes (Hall et al. 1980, Freda 1986, LeFevere and Sharpe 2002, McClurg et al. 2007), as well as a reduction in ecosystem processes (Gessener and Chauvet 2002). Leaf litter break down was indicated to be hindered in acidic streams (Gessener and Chauvet 2002, Dangles et al. 2004, Simon et al. 2009). The reduction in leaf litter breakdown with increased acidity is usually linked with a reduction of invertebrates and/or microbes at low $\mathrm{pH}$ (Suberkropp and Chauvet 1995, Mckie et al. 2006, Simon et al. 2009).

Acid mine drainage incorporates several individual stressors, any one of which can affect aquatic communities. Stressors from acid mine drainage include acidity, high concentrations of dissolved metals and precipitated metal oxides (Niyogi et al. 2002, Merovich et al. 2007, Petty et al. 2010). The combination of these stressors can reduce leaf litter breakdown through their effects on invertebrates and microbial activity (Niyogi et al. 2002, Schliet 2004, Barnden and Harding 2005). The formation of metal oxide precipitates may limit fungal and bacterial activity as the plaque covers the leaves and fungal hyphae (Niyogi et al. 2002, Schliet 2004, Schlief and Mutz 2006). Shredder biomass is highly impacted by dissolved metals and precipitation of metal oxides (Niyogi et al. 2002). It has been noted that microbial activity appears to have a higher threshold than invertebrate biomass to dissolved metals and depressed pH (Niyogi et al. 2002). As such, the leaf litter breakdown process in acidic mine drainage streams is slow and primarily microbial mediated (Schliet 2004).

The central Appalachian eco-region receives some of the highest rates of acid deposition in the United States (McClurg et al. 2007). Many areas within this region have geologies of little limestone leaving most streams with little to no buffering capacity. In addition to acid precipitation, areas within this region have been intensively mined for high sulfur coal, adding an acid mine drainage influence to the streams of the region. While much effort has been dedicated to the understanding of the how acid precipitation and acid mine drainage affect 
fish and invertebrate communities (Petty et al. 2005, McClurg et al. 2007, Merovich and Petty 2007, Merovich et al. 2007, Merovich and Petty 2010, Petty et al. 2010), the effect of acid stressors on ecosystem functions remains poorly understood. Furthermore, the relative importance of invertebrate shredder and microbial communities in leaf litter breakdown in these two types of acid contaminated streams is largely unknown. Consequently, the objectives of this study were to: 1) quantify the effect of acid precipitation and acid mine drainage on leaf litter decomposition rates; 2 ) determine the relative importance of invertebrate shredder and microbial communities in determining leaf litter decomposition rates; and 3) compare leaf litter decomposition with macroinvertebrate indices commonly used as measures of stream ecosystem health.

\section{Study Area}

Our study was conducted in the Cheat River watershed located in the Central Appalachian Mountains, within the Appalachian plateau and Ridge and Valley physiographic province in north-central West Virginia, USA. The Cheat River, which drains approximately 3683 $\mathrm{km}^{2}$, is a north-flowing tributary of the Monongahela River. The majority of the watershed is forested with some low intensity agriculture (Merovich and Petty 2010). The geology of the watershed is predominantly sandstone and shale with limited out-crops of Greenbrier limestone (Figure 2) (Freund and Petty 2007). The lower portion of the Cheat River watershed possesses extensive coal deposits of the Upper and Lower Freeport, Upper and Lower Kittanning, Pittsburgh and Bakerstown seams, which are mostly considered to have a high pyrite concentration (Freund and Petty 2007, Petty et al. 2010). This area has undergone extensive mining, both surface and underground, much of which was carried out prior to passage of the federal law regulating the mining industry (Figure 3) (Petty et al. 2010). There are approximately 60 regulated and 185 abandoned mines discharging AMD into the lower portion 
of the Cheat River (Petty et al. 2010). This area also receives one of the highest acid loading rates from acid precipitation in the eastern US (McClurg et al. 2007). A combination of the spatial variation of AMD discharge and geologies with natural buffering capacity create unique water chemistry types within the lower portion of the Cheat River watershed (Merovich et al. 2007).

\section{Site selection}

I studied 15 streams within the lower portion of the Cheat River Watershed: 5 impacted by acid precipitation (AP), 5 impacted by acid mine drainage (AMD) and 5 naturally circumneutral (CN) (Figure 4). Naturally circumneutral streams were selected within the study area to act as reference conditions against which any changes in decomposition in AP or AMD streams were judged. Naturally circumneutral streams with little anthropogenic impairment represent the best available conditions in the region (McClurg et al. 2007) and provide the only reasonable reference condition against which to detect changes in decomposition. AP streams were selected based on water chemistry characterized by low $\mathrm{pH}$, zero alkalinity, calcium, and magnesium, and low conductivity and sulfate (Table 1). AP streams typically drain un-mined watersheds with a geology dominated by sandstone (Merovich et al. 2007). AMD streams were selected based on water chemistry characterized by extremely low $\mathrm{pH}$, extremely high conductivity and high concentrations of dissolved metals and sulfate (Table 1). AMD streams drain intensively mined watersheds containing high pyrite coal with little chemical treatment and no natural buffering capacity (Petty et al. 2010). Study sites were selected to control for several of the factors that can influence leaf litter decomposition, including stream flow, water temperature, and channel gradient (Royer and Minshall, 2003). The study sites were first through third order streams (Table 2), and all streams possessed similar habitat characteristics (small, cold-water, cobble bed streams of moderate slope). 


\section{Methods}

\section{Water chemistry, temperature, and flow}

Water chemistry samples were taken at each site every 40 days over the course of a year starting June 15, 2009. These water samples were taken with the placement and removal of leaf packs (Simon et al. 2009). Two water samples were collected from each stream during each visit following procedures used by Freund and Petty (2007), McClurg et al. (2007), Merovich et al. (2007), and Petty et al. (2010). A filtered sample was collected for analysis of dissolved metals. This sample was collected with a $60 \mathrm{~mL}$ syringe and filtered through a mixed cellulose ester membrane disc with a pore size of $0.45 \mu \mathrm{m}$. The sample was then acidified with approximately $5 \mathrm{~mL}$ of concentrated hydrochloric acid to keep metals dissolved in solution. These samples were analyzed for aluminum, barium, calcium, cadmium, cobalt, chromium, copper, iron, magnesium, manganese, sodium, nickel, selenium, and zinc using inductively coupled plasma/atomic emission spectrometry (EPA 1991; method 200.7). Chloride was also analyzed from these samples using ion chromatography (EPA 1991; method 325.2).

An unfiltered $250 \mathrm{~mL}$ grab sample was collected at each site at each visit. These samples were collected while completely submerging the sample bottle taking care to remove any air bubbles thereby eliminating contact between the water sample and air. These samples were analyzed for alkalinity and acidity using an automatic titrator (EPA 1991; methods 310.1 and 305.2 respectively), sulfate using ion chromatography (EPA 1991; method 375.4), and total suspended solids. Both samples were stored at $4{ }^{\circ} \mathrm{C}$ until they were analyzed. All chemical analysis was conducted at the WVU National Research Center for Coal and Energy. Field measurements of $\mathrm{pH}$, temperature $\left(\mathrm{C}^{\circ}\right)$, specific conductivity $(\mu \mathrm{S} / \mathrm{cm}$, and total dissolved solids (g/L) were taken with a multiparameter YSI 650 (Yellow Springs Instruments, Yellow Springs, $\mathrm{OH}, \mathrm{USA}$ ). Discharge was calculated during every sampling using the area-velocity technique 
with velocity measured with a Marsh-McBirney Flow-Mate (Marsh-McBirney, Frederick, Maryland, USA).

\section{Leaf packs}

Leaf packs were deployed to cover the summer growing season, the winter season when leaves would typically enter the stream system, and the spring season. Each leaf pack consisted of $10 \mathrm{~g}$ of air dried whole Pin Oak (Quercus palustris) leaves, a native species. These leaves were all simultaneously collected immediately after leaf fall in November 2007. For each season 18 leaf packs were placed in a low flow zone of the stream (pools, back waters) (Fritz et al. 2010). Leaf packs were placed June 15, 2009, October 11, 2009, and March 26, 2010. Six of the 18 packs were removed at 40-day intervals over the 120-day deployment. Upon removal, the packs were placed in plastic bags, kept on ice, and returned to the lab. In the lab leaves were rinsed to remove any sediment or metal oxide. The leaves were then placed in paper bags to air dry for 14 days. At this point the leaves were weighed to obtain their dry mass. Ash free dry mass was then obtained by taking a $25 \mathrm{mg}$ subsample of the dry mass and combusting it at $550^{\circ} \mathrm{C}$ for 30 minutes (Benfield 1996). The ash mass was then calculated for the entire sample and subtracted from the dry mass to obtain the ash free dry mass (AFDM). Once the ash free dry mass was estimated for each of the 40 day interval samples leaf decomposition rate was calculated as remaining ash free dry weight versus time. To account for mass lost due to handling, an extra leaf pack was taken to each site during deployment and then returned to the lab where it was processed alongside the rest of the leaf packs. An exponential model $L_{t}=L_{0} e^{-K t}$ was fitted to remaining leaf mass where $L_{t}$ is the AFDM at time $t, L_{0}$ is the AFDM derived from the handling pack, and $\mathrm{k}$ is the estimated leaf litter decomposition rate (Simon et al. 2009). 


\section{Benthic macroinvertebrates}

Benthic macroinvertebrates were sampled twice a year, once in May and once in November. Macroinvertebrate sampling was modeled after EPA Rapid Bioassessment Protocols for wadeable streams (WVDEP, 1996, Barbour et al. 1999, WVDEP, 2003). Macroinvertebrates were collected from four separated riffles within each stream. A kick net $(50 \mathrm{~cm} \times 30 \mathrm{~cm})$ was used for collection with the area of the net being kicked for benthic macroinvertebrates. Once collected, the samples from the four riffles were combined and preserved in $95 \%$ ethanol and returned to the lab. Upon return to the lab the samples were filtered through $2 \mathrm{~mm}$ and then $250 \mu \mathrm{m}$ sieves thereby separating the larger macroinvertebrates from the smaller ones. All macroinvertebrates greater than $2 \mathrm{~mm}$ were identified. All material passing through the $2 \mathrm{~mm}$ sieve was split to a $1 / 8^{\text {th }}$ subsample using a Folsom phytoplankton splitter (Model number 1831-F10, Wildco Supply Company, Buffalo, NY) (Merovich et al. 2007, Merovich and Petty 2010, Petty et al. 2010). All taxa of the class insecta were identified to Genus level and all other taxa were identified to order Using Merritt and Cummins (1996) and Peckarsky et al. (1990). Macroinvertebrate assemblages were defined by macroinvertebrate density and diversity. The macroinvertebrates were categorized into functional feeding groups and the shredder assemblage was determined based on functional feeding group classifications of Merritt and Cummins (1996). Finally, the West Virginia stream condition index (WVSCl) score and a number of other macroinvertebrate metrics (number collected, percent EPT, EPT genus richness, percent tolerant, percent Ephemeroptera, modified hilsenhoff index, percent dominant, family richness, percent acid tolerant, and percent aluminum tolerant) were obtained for each stream (Tetra Tech 2000) to examine their ability to predict stream leaf litter breakdown function in regards to classified stream health. 


\section{Microbial Activity}

Microbial activity was measured in two ways: ergosterol concentration of exposed leaves was calculated to estimate fungal activity (Simon et al. 2009, Fritz et al. 2010) and biological oxygen demand was determined to estimate total microbial activity of microbes that had colonized the leaf matter (Niyogi et al. 2001, Schlief 2004, Simon et al. 2009). Additional leaf packs were placed alongside the leaf packs in the decomposition study. These leaf packs contained pin oak leaves consistent with those used in the decomposition study. Packs were constructed with $2 \mathrm{~mm}$ screen to exclude any macroinvertebrates and retain leaf matter. These packs were collected in conjunction with the decomposition packs at 40,80 , and 120 days. Half of the leaf matter in these packs was used to measure ergosterol concentration and the other half was used to measure biological oxygen demand.

\section{Ergosterol}

Ergosterol is a sterol with a rare UV sensitive double bond. It is found in cell walls of fungi, but is absent from vascular plants and non-fungal microbes, which makes it particularly useful for estimating fungal abundance (Newell et al. 1988). Fungal activity was estimated by extracting and quantifying ergosterol concentration from finely ground leaf litter (Newell et al. 1988, Kuehn et al. 2000). A modified form of the cold ethanol procedure described in Richardson and Logendra (1997) was used. Leaf litter was lightly rinsed to remove sediment and metal oxides, then air dried and ground to a powder. Leaf litter $(0.2 \mathrm{~g})$ and $1 \mathrm{~mL}$ of absolute ethanol was combined in 2-mL, screw-cap microcentrifuge tubes (Fisher Scientific, Pittsburgh, PA) in a FastPrep FP120 (Q-biogene, Irvine,CA) with agitation at $6.0 \mathrm{~m} / \mathrm{s}$ for $30 \mathrm{~s}$. Ergosterol was then extracted for 30 min by rotating, end-over-end at $15 \mathrm{rpm}$, on a Glas-Col (Terre Haute, IN) mini-rotator. Samples were centrifuged for $10 \mathrm{~min}$ at 10,000 rpm in a VSB-14 microcentrifuge (Shelton Scientific, Shelton, CT) before the supernatant was removed and 
filtered through a 0.22- $\mu$ m nylon filter microcentrifuge tube (Costar, Corning, NY), by centrifugation for $2 \mathrm{~min}$ at 10,000 rpm (Gingerich, unpublished).

Ergosterol concentration was determined by high-performance liquid chromatography (HPLC) on a $150 \mathrm{~mm} \times 4.6 \mathrm{~mm}$ Phenomenex Prodigy 5- $\mathrm{mm}$ ODS3 reverse phase C18 column (Phenomenex, Torrance, CA). As described in Panaccione \& Coyle (2005), HPLC conditions consisted of a model 600 pump controller with an in-line degasser, a model 717 plus autosampler, and a model 2487 absorbance detector (Waters Corp., Milford, MA). Samples were eluted isocratically with $100 \%$ methanol at a flow rate of $1.0 \mathrm{~mL}$ per minute, and peaks were monitored at $280 \mathrm{~nm}$ wavellength. Ergosterol was eluted at about 9 minutes (UV absorption in $\mathrm{MeOH}, \lambda \max =282$ with shoulders at 269 and 293). Ergosterol from samples was quantified by comparing sample peaks to peaks of pure compound ergosterol standard (MP Biomedicals, Solon, $\mathrm{OH}$ ) at 2, 20, and $200 \mu \mathrm{g} / \mathrm{mL}$ (Gingerich, unpublished). Ergosterol is expressed as $\mu \mathrm{g}$ ergosterol per $\mathrm{mL}$ extraction solvent.

\section{Biologic oxygen demand}

Respiration rate of the entire microbial community that had colonized exposed leaves was estimated by measuring dissolved oxygen concentrations (Ward and Johnson 1996). Leaves were not rinsed. Metal oxide precipitates might influence respiration rate. We wanted to keep conditions close to those of the respective stream. Five $4 \mathrm{~cm}^{2}$ leaf pieces were cut from each leaf pack; area was used instead of weight as coatings of metal oxide could drastically skew leaf material used from one stream to another. The five leaf pieces were submerged in $300 \mathrm{~m}$ of deionized water in darkened and stoppered biological oxygen demand bottles (Environmental Express, Mt. Pleasant, SC). Dissolved oxygen concentration of the $300 \mathrm{~mL}$ deionized water was measured prior to adding the leaf pieces with a Smart USB Dissolved Oxygen Sensor (Nexsens Technology, Yellow Springs, $\mathrm{OH}$ ) and then again 24 hours after the 
leaf pieces were added. Respiration rate was determined by subtracting the 24 hour dissolved oxygen concentration from the initial dissolved oxygen concentration. Respiration rate is expressed as mg of oxygen used per L per day.

\section{Statistical analyses}

Leaf litter decomposition rate was calculated at each stream for each season. Using the seasonal decomposition rates, an annualized average decomposition rate also was calculated for each stream. The annual average decomposition rate was used in much of the analyses. Water chemistry variables were collected four times over the course of a decomposition trial, and averaged over the course of each trial for each stream. The annual average of water chemistry variables was also found for each stream and used for much of the analyses. The two seasonal macroinvertebrate community samples from each site were averaged together before being used in analysis.

Principal components analysis (PCA) was used to confirm stream classification into three types (CN, AP, and AMD). PCA reduces the dimensionality of a large multivariate dataset to a few derived variables, which are ordered by the amount of variance they explain (Hair et al. 1995). Water chemistry values from each site for all three seasons were used to create the PC axes. Some water chemistry variables were excluded from the PCA analysis because they were only detected in low concentrations and never differed between site types; these chemistry variables were $\mathrm{Ba}, \mathrm{Cr}, \mathrm{Cu}, \mathrm{Se}$, and total suspended solids. The water chemistry variables conductivity, alkalinity, acidity, $\mathrm{Al}, \mathrm{Ca}, \mathrm{Cl}, \mathrm{Co}, \mathrm{Fe}, \mathrm{Mg}, \mathrm{Mn}, \mathrm{Na}$, and $\mathrm{Ni}$ were log transformed to homogenize variance and meet normality assumptions of parametric statistics (Merovich et al. 2007). PCs with eigenvalues greater than 1 were considered statistically significant and variables with factor loadings greater than $|0.4|$ were considered to explain a statistical proportion of the variation in a PC (McCune and Grace 2002). Sites were plotted on PC axes 
based on the seasonal water chemistry for each of the three seasonal decomposition trials. Principal components analysis was conducted in the R Project for Statistical Computing Version 2.8.0 (R Development Core Team 2008) using the package LabDSV (Roberts 2007).

Nonmetric multidimensional scaling (NMDS) of macroinvertebrate communities was used to confirm our assumption that streams within a type would have similar macroinvertebrate communities. NMDS creates a map of samples in two or more dimensions where the relative distance apart reflects the relative similarity in the species composition (Clarke 1993). A two dimensional model was used with a stress of 7.36. All collected taxa were included in this model. NMDS was conducted in the R Project for Statistical Computing Version 2.8.0 (R Development Core Team 2008) using the package vegan (Oksanen et al. 2008).

For each season's decomposition trial a repeated measures analysis of variance (ANOVA) ( $\alpha=0.05)$ was used to test the effects of days of exposure and stream type on remaining leaf mass (Wider and Lang 1982). Remaining leaf mass was tested for normality using Shapiro Wilks test of normality, normality was approximate for all three seasons and could not be improved by transformations. Effect of stream type on decomposition rate was tested using an ANOVA $(\alpha=0.05)$ for each seasonal trial, followed by a Tukey HSD post hoc test to assess differences between specific stream type contrasts. Influence of seasonality was addressed using a two-way ANOVA $(\alpha=0.05)$ where the effects of season (summer 2009, winter 2009, spring 2010) and stream type on decomposition rates were tested. Trends in decomposition rate were found using the annual average decomposition rates for each stream. An ANOVA ( $\alpha=0.05)$ was used to determine the effect of stream type on the annual average decomposition rate. This was followed by a Tukey HSD post hoc test to determine where differences were. ANOVAs and Tukey HSD post hoc tests were conducted in the R Project for Statistical Computing Version 2.8.0 (R Development Core Team 2008). 
ANOVAs $(\alpha=0.05)$ were used to determine if there were differences in physical stream parameters (annual average water temperature, drainage area, slope and annual average discharge) among the site types. The influence of physical parameters (drainage area, water temperature, discharge, slope) on decomposition rate were analyzed using an analysis of covariance (ANCOVA) ( $\alpha=0.05)$ where annual average decomposition rate was analyzed by physical parameter and stream type. Correlation analysis was used within each site type to examine relationships between temperature, drainage area, slope and discharge and decomposition rate. ANOVAs, and ANCOVAs were conducted in the R Project for Statistical Computing Version 2.8.0 (R Development Core Team 2008).

Macroinvertebrate community data collected from each site was used to generate information on the shredder functional feeding group. Cluster analysis was performed on the shredder assemblages from each site, using Ward's minimum variance method and Bray-Curtis distance measure to define clusters. Analysis of similarity (ANOSIM) on Bray-Curtis distance coefficients was run on the shredder assemblages from each site to test whether shredder assemblages were significantly different among stream types (Clarke and Green 1988, Clarke 1993, Merovich and Petty 2010). Statistical significance of R was assessed with 1000 permutations. Post hoc pairwise tests were run to determine between which stream types shredder assemblages differed. Cluster analysis and ANOSIM were conducted in the R Project for Statistical Computing Version 2.8.0 (R Development Core Team 2008) using the package vegan (Oksanen et al. 2008).

Total shredder abundance, shredder richness, total number of voracious shredders (Wallace et al. 1996, Dangles and Guerold 2001, Schofield et al. 2001, Mckie et al. 2006, and Simon et al. 2009), total shredding Plecoptera, total shredding Trichoptera, total number of Nemouridae, and total number of Tipulidae (Appendix I) were calculated as potential factors influencing decomposition rate. ANOVAs $(\alpha=0.05)$ were run to compare these shredder 
abundances among the three site types. ANCOVAs $(\alpha=0.05)$ were used to evaluate any effect these shredder abundances had on annual average decomposition rates in conjunction with stream type. Shredder abundances were also correlated with decomposition rate for each site type. Macroinvertebrate metrics (WVSCI, \%EPT, EPT genus richness, \% tolerant, \% dominant, $\mathrm{MHI}$ and Family richness) were calculated from the macroinvertebrate community sampled. ANOVAs $(\alpha=0.05)$ were run on each of these macroinvertebrate metrics to determine any differences between stream type. Correlations $(\alpha=0.05)$ were run on these macroinvertebrate metrics to determine how these metrics relate to annual average decomposition rate.

ANOVAs $(\alpha=0.05)$ were used to compare ergosterol concentration and respiration rate between stream types. ANCOVAs $(\alpha=0.05)$ were used on these microbial activity indicators in conjunction with stream type to determine if they had an impact on the annual average decomposition rate. Microbial activity indicators were also correlated with annual average decomposition rate within each stream type and over all three stream types. ANOVAs, ANCOVAs and correlations were conducted in the R Project for Statistical Computing Version 2.8.0 (R Development Core Team 2008).

Akaike's information Criterion (AIC) was used to select a generalized linear model to predict decomposition rate based on several likely parameters collected (number voracious shredders, total number of shredders, shredder richness, ergosterol concentration, microbial respiration, water temperature, and discharge). AIC selects the best model from the candidate models created from combinations of the likely parameters and ranks them from best to worst (Burnham and Anderson 2002) A step wise procedure within the R Project for Statistical Computing Version 2.8.0 was used to generate models (R Development Core Team 2008). AIC corrected $(\mathrm{AIC})$ scores were used to account for small sample size as the sample size to model parameter ratio was always less than 40 (Burnham and Anderson 2002). 


\section{Results}

\section{General characteristics of streams}

Drainage area, discharge, temperature and slope

The drainage area of the study streams did not differ between the study sites, nor did the annual average discharge. However, the annual average temperature was significantly higher in AMD streams than in both $\mathrm{CN}$ streams and AP stream and the slope of AMD streams was significantly lower than both CN and AP streams (Table 3).

\section{Water chemistry}

PCA

PCA illustrates that water chemistry differs among the three site types for all three seasonal decomposition trials. Two PCs were identified with the first explaining $72.7 \%$ of the variation and the addition of the second PC explaining $83.8 \%$ of the variation. Factors most significantly loading on PC axis 1 were $\mathrm{pH}(r=-0.86)$, conductivity $(r=0.94)$, alkalinity $(r=-0.71)$, acidity ( $r=0.65)$, sulfate $(r=0.94)$ and a number of dissolved elements; $\mathrm{Al}(r=0.97), \mathrm{Ca}(r=0.83)$, $\mathrm{Cl}(\mathrm{r}=0.68)$, $\mathrm{Co}(\mathrm{r}=0.89), \mathrm{Fe}(\mathrm{r}=0.89), \mathrm{Mg}(\mathrm{r}=0.94), \mathrm{Mn}(\mathrm{r}=0.96), \mathrm{Na}(\mathrm{r}=0.57), \mathrm{Ni}(\mathrm{r}=0.87)$, and $\mathrm{Zn}$ $(r=0.96)$. Factors most significantly loading on PC axis 2 were alkalinity $(r=-0.54)$, acidity $(r=0.46), \mathrm{Ca}(r=-0.45)$ and $\mathrm{Na}(r=-0.64)$ (Table 4). For all three seasons AMD type streams were clearly distinguished from CN streams and AP streams along PC axis 1 (Figure 5a,b, and c), with AMD streams consistently plotting on the positive side of this axis and AP and CN streams consistently plotting on the negative side. AP streams and CN streams were not separated from one another along PC axis 1. For all three seasons AP streams and CN streams were 
separated along PC axis 2, with CN streams consistently plotting more towards the positive end than AP streams. For all three seasons stream were clustered by stream type and each type is distinct from the other two types.

\section{Differences in water chemistry among stream types}

Stream types differed in many of the water chemistry variables analyzed. All three stream types $\mathrm{CN}, \mathrm{AP}$, and AMD had significantly different $\mathrm{pH}(\mathrm{p}<0.001)$ for summer, winter, and spring decomposition trials (Tables 5, 6, and 7). Water temperature differed between AMD streams and both CN and AP streams $(p<0.01)$ during the summer, between AP stream and both $\mathrm{CN}$ and AMD streams $(\mathrm{p}<0.01)$ in the spring decomposition trial, but did not differ among stream types during the winter decomposition trial (Tables 5, 6, and 7). Conductivity and concentration of total dissolved solids differed between AMD streams and the other two stream types $\mathrm{CN}$ and AP in all three seasonal trials $(p<0.001)$ (Tables 5, 6, and 7). Discharge differed between AMD streams and AP streams $(p<0.1)$ in the summer decomposition trial (Table 5), but did not differ in the other two seasons. Concentration of alkalinity differed between $\mathrm{CN}$ streams and the other two stream types: AMD and AP in both the summer $(p<0.001)$ and winter $(p<0.001)$ decomposition trial (Tables 5 and 6$)$, but only differed from AMD streams in the spring decomposition trial $(p<0.001)$ (Table 7$)$. Concentration of acidity $(p<0.001, p<0.001, p<0.1)$, a number of dissolved elements: $\mathrm{Al}$ ( $p<0.001$ all trials), Ca ( $p<0.001$ all trials), Fe $(p<0.01$, $p<0.01, p<0.001), M g(p<0.001$ all trials), $\mathrm{Mn}(p<0.001, p<0.001, p<0.01), \mathrm{Na}(p<0.1, p<0.001$, $p<0.01), \mathrm{Ni}(p<0.001, p<0.001, p<0.01)$, and $\mathrm{Zn}(\mathrm{p}<0.001$ all trials $)$, and sulfate $(p<0.001$ all trials) differed between AMD streams and the other two types: CN and AP for summer, winter and spring decomposition trials (Tables 5, 6, and 7). Concentration of $\mathrm{Ba}, \mathrm{Cl}, \mathrm{Co}$, $\mathrm{Cu}$ did not consistently differ among stream types for the three seasonal trials (Table 5, 6, and 7). Concentrations of total suspended solids, Se, and Cr never differed among any of the stream types (Tables 5, 6, and 7). 
$\underline{\text { Seasonal variation within site types }}$

There was seasonal variation in discharge independent of stream type and seasonal variation of stream temperature with some interaction with stream type (Table 8). Moderate seasonal variations in stream chemistry parameters were seen. Half of the chemistry parameters measured varied seasonally, including $\mathrm{pH}$, specific conductivity, total dissolved solids, alkalinity, $\mathrm{Al}, \mathrm{Ba}, \mathrm{Cu}, \mathrm{Mg}, \mathrm{Na}$, and Se. However, most of these seasonal variations interacted significantly with the stream type so no clear trends were observed. A few trace elements, $\mathrm{Ba}, \mathrm{Cu}, \mathrm{Na}$, and $\mathrm{Se}$, had seasonal variations independent of stream type and tended to be elevated during the summer trial, with the exception of Ba which was elevated during the spring trial. However, PCA of mean water chemistry for each site with standard error bars shows that sites varied little in their water chemistry between seasons and did not stray from their allotted stream type (Figure 6).

\section{Macroinvertebrates}

NMDS ordination showed that macroinvertebrate assemblage structure was strongly related to stream type (Figure 7A). Assemblages from AMD streams were not tightly grouped but they were clearly separated from the AP and CN assemblages. Community assemblages from CN streams and AP streams were tightly clustered, and were separate from one another. Many of the water chemistry variables measured were statistically correlated with this NMDS solution (Table 9). Conductivity $\left(r^{2}=0.89\right), \mathrm{pH}\left(r^{2}=0.91\right), \mathrm{Al}\left(r^{2}=0.85\right), \mathrm{Ca}\left(r^{2}=0.91\right), \mathrm{Mg}\left(r^{2}=0.84\right), \mathrm{Ni}$ $\left(r^{2}=0.85\right) \mathrm{Zn}\left(r^{2}=0.89\right)$ and $\mathrm{SO}_{4}\left(r^{2}=0.091\right)$ had the strongest linear relationship with the ordination. $\mathrm{pH}$ was related to axis 1 with high $\mathrm{pH}$ associated with $\mathrm{CN}$ community assemblages. High conductivity, sulfate, $\mathrm{Al}, \mathrm{Mg}$, and Ca were inversely associated with high axis 1 scores and low axis 2 scores and were associated with many of the AMD community assemblages (Figure 7B). Several invertebrate metrics were associated with the placement of community 
assemblages (Table 9). WVSCI $\left(r^{2}=0.91\right)$, Family richness $\left(r^{2}=0.95\right)$ and EPT genus richness $\left(r^{2}=0.90\right)$ were related to axis 1 and were associated with $C N$ community assemblages.

Percent dominant taxa $\left(r^{2}=0.85\right)$ and percent tolerant $\left(r^{2}=0.81\right)$ were inversely related to axis 1 and were associated with AMD community assemblages (Figure 7C).

Based on the results of ANOVAs all invertebrate metrics calculated varied between stream types (Table 10). WVSCI scores, EPT genus richness, and family richness differed between all three site types with $\mathrm{CN}$ streams having the highest scores and AMD streams having the lowest scores. Percent tolerant and percent dominant also differed between the three stream types with AMD streams having the highest scores and $\mathrm{CN}$ streams having the lowest scores. AMD streams differed from both $\mathrm{CN}$ and AP streams types having lower total number of invertebrates collected and percent EPT, and having a higher MHI score. CN streams had a higher percent Ephemeroptera than the other two stream types. AP streams had a higher percent of acid tolerant species than both AMD and CN streams.

Cluster analysis resulted in near perfect groupings of shredder assemblages by stream type within two hierarchical levels (Figure 8). At the first level the AMD assemblage cluster was differentiated from $\mathrm{CN}$ and AP assemblages. At the second level, with the exception of one AP stream, CN assemblages were differentiated from AP assemblages. The global ANOSIM also indicated that there was statistically greater dissimilarity in shredder assemblage among stream types than if assemblages were random. Pairwise ANOSIMS between stream types indicated that all stream types had statistically different shredder assemblages (Table 11).

The number collected and several of the taxa comprising the shredder functional feeding group differed between stream types (Table 12). Total number of shredders differed among the three stream types with AP streams having the most shredders and AMD streams having the fewest number of shredders. Number of Nemouridae differed between AP streams 
and the other two stream types with AP streams having the greatest number of Nemouridae. Shredder richness and the number of shredding Plecoptera differed between AMD streams and the other two stream types. Number of voracious shredders, shredding Tipulidae and Trichoptera did not significantly differ among the three stream types.

Shredder community assemblages were different between the three stream types. AMD streams had few if any shredders. Shredder taxa found in AMD streams included Asellidae, and a few Plecoptera taxa (Leuctra, Amphinemuera, and Taeniopteryx) (Figure 9a). Shredder assemblages in AP streams were dominated by Plecoptera taxa (Leuctra (39\%) and Nemouridae (46\%)). The Isopod Asellida (4\%), and Plecoptera taxa (Capniidae (4\%), Peltoperla (1\%) and Taeniopteryx (3\%)) were also abundant (Figure 9b). Shredder assemblages in CN

streams contained a number of contributing taxa, including Amphipod (Gammarus) (37\%), and Plecoptera taxa (Leuctra (28\%) and Nemouridae (16\%), however, their quantities were highly variable. Other contributing taxa include, the Decopod Cambarus (1\%), the Isopod Asellidae (3\%), the Trichoptera taxa (Polycentropus (4\%), and Lepidostoma(1\%)), the Plecoptera taxa (Peltoperla (3\%), Petronarcys (1\%) and Taeniopteryx (3\%)), and the Diptera Tipulidae (2\%) (Figure 9c).

\section{Microbial activity}

Microbial activity differed statistically among stream types (Table 13). Community respiration was significantly higher in $\mathrm{CN}$ streams than in AP and AMD streams. Ergosterol concentration was significantly higher in $\mathrm{CN}$ streams than AMD streams but did not differ between CN streams and AP streams. Respiration and ergosterol did not differ significantly between AP and AMD streams (Table 13). 


\section{Decomposition}

Stream type and days of exposure significantly influenced remaining leaf mass during all three seasons of the study (Table 14, Figures 10a, b, and c). Decomposition rates in study streams ranged from 0.001 (g/day) in an AMD stream to 0.034 (g/day) in a CN stream over the course of a year (Table 15). Annual Average decomposition rates ranged from 0.002 (g/day) in an AMD stream to 0.025 (g/day) in a CN stream (Table 15). Statistical differences were observed in decomposition rates among the stream types during summer $(p=0.03)$ and winter $(p=0.01)$ seasons and when decomposition rates were averaged over the entire year $(p=0.009)$ (Table16). Decomposition rates were statistically higher in CN streams than AMD streams in summer and statistically higher in $\mathrm{CN}$ streams than AMD and AP streams in winter. Statistical differences were not observed in decomposition rates among stream types during the spring trial $(p=0.17)$.

Results of a two-way ANOVA indicated a significant effect of stream type on decomposition rates but no effect of season. A site by season interaction effect also was not significant (Table17, Figure11). The annual average decomposition rate differed significantly between $\mathrm{CN}$ streams and both AP and AMD streams. The general trend observed was CN streams had the highest decomposition rate, AMD type streams had the lowest decomposition rate and decomposition rates for AP type streams were intermediate (Figure 12).

\section{Abiotic Influences on Decomposition}

Given the results of ANCOVAs on annual average decomposition rate of site types by catchment size and physical water characteristics drainage area, annual average stream temperature and annual average discharge were influential in determining annual average 
decomposition rate (Table 18). However, stream slope was not influential in determining annual average decomposition rate. Drainage area was strongly correlated with annual average decomposition rate in $C N$ streams $\left(R^{2}=0.69\right)$ and slightly correlated with $A P$ streams $\left(R^{2}=0.21\right)$ but not correlated with AMD stream (Figure 13a). There was no strong positive correlation between annual average stream temperature and annual average decomposition rate for any of the stream types (Figure 13b). The annual average discharge was moderately correlated with annualized decomposition rate of AP streams $\left(R^{2}=0.48\right)$, slightly correlated with $C N$ streams $\left(R^{2}=0.23\right)$, but was not correlated with AMD streams (Figure 13c). Stream slope was not correlated with the annual average decomposition rate of $\mathrm{CN}$ or AP streams but was slightly correlated with AMD streams $\left(R^{2}=0.18\right)$ (Figure 13d).

\section{Biotic Influences on Decomposition}

ANCOVAs relating total number of shredders, shredder richness, voracious shredders and abundance of a number of shredder taxa to annual average decomposition rate indicate that most shredder abundances were not influential on decomposition rate over all three stream types (Table 19). The only shredder abundance that was associated with annual average decomposition rate over all three site types was number of shredding Trichoptera (F-value $=$ 4.41, $p$-value $=0.07)$. Total number of shredders was strongly correlated with annual average decomposition in AMD streams $\left(R^{2}=0.73\right)$, was very weakly correlated in AP streams $\left(R^{2}=0.12\right)$, and was negatively correlated in CN streams (Figure 14a). Shredder richness was strongly correlated with annual average decomposition rate in AP streams $\left(R^{2}=0.73\right)$, was weakly correlated in $\mathrm{CN}$ streams $\left(\mathrm{R}^{2}=0.16\right)$, but was not correlated in AMD streams (Figure 14b). Number of voracious shredders was slightly correlated with annual average decomposition in AP streams $\left(R^{2}=0.29\right)$, but not correlated in AMD or CN streams (Figure 14c). Number of 
shredding Trichoptera was correlated with annual average decomposition rate in CN streams $\left(R^{2}=0.54\right)$, weakly correlated in AP streams $\left(R^{2}=0.11\right)$, and not correlated in AMD streams (Figure 14d). Number of shredding Plecoptera was correlated with annual average decomposition in AMD streams $\left(R^{2}=0.58\right)$, weakly correlated in AP streams $\left(R^{2}=0.17\right)$, and negatively correlated in CN streams (Figure 14e). Number of shredding Tipulidae was weakly correlated with annual average decomposition in AP streams $\left(R^{2}=0.23\right)$, not correlated in $C N$ streams and negatively correlated in AMD streams (Figure 14f). Number of Nemouridae was correlated with annual average decomposition rate in AMD streams $\left(R^{2}=0.59\right)$, weakly correlated in AP streams $\left(\mathrm{R}^{2}=0.14\right)$, and not correlated in $\mathrm{CN}$ streams (Figure $14 \mathrm{~g}$ ).

Correlations of a number of macroinvertebrate metrics with annual average decomposition rate indicate that no metrics were strongly associated with decomposition rate (Table 20). WVSCI score $\left(R^{2}=0.22\right)$, number of invertebrates $\left(R^{2}=0.35\right)$, EPT genus richness $\left(R^{2}=0.51\right)$, percent tolerant taxa $\left(R^{2}=0.25\right)$, percent Ephemeroptera $\left(R^{2}=0.25\right)$, percent dominant $\left(R^{2}=0.27\right)$, family richness $\left(R^{2}=0.43\right)$, and percent $A$ l tolerant $\left(R^{2}=0.22\right)$ were all weakly correlated.

ANCOVAs relating the covariates microbial respiration and ergosterol concentration to annual average decomposition rate show that both respiration rate $(F$-value $=12.37, p$-value $=$ 0.006) and Ergosterol $(F$-value $=14.46, p$-value $=0.004)$ are associated with decomposition rate (Table 21). Microbial respiration rate was highly correlated to annual average decomposition rate in $C N$ streams $\left(R^{2}=0.74\right)$, weakly correlated in AMD streams $\left(R^{2}=0.20\right)$ and negatively correlated in AP streams $\left(R^{2}=0.17\right)$ (Figure 15a). Respiration rate was highly correlated to annual average decomposition rate over all site types $\left(R^{2}=0.64, p\right.$-value $\left.<0.001\right)$ (Figure 15b). Ergosterol concentration was highly correlated to annual average decomposition rate in $\mathrm{CN}$ streams $\left(R^{2}=0.89\right)$, but not correlated in AP streams and negatively correlated in AMD streams 
(Figure 15c). Ergosterol concentration was correlated with annual average decomposition rate over all site types $\left(R^{2}=0.59, p\right.$-value $\left.<0.001\right)$ (Figure $\left.15 d\right)$.

Of the models tested using the AIC approach, the model identified with the lowest AICc score contained only ergosterol concentration and microbial respiration (Equation1), it had an Akaike weight of 0.91 (Table 22) and an adjusted $R^{2}$ of 0.70 . The model with the second lowest AICc score contained voracious shredders, shredder richness, microbial respiration, stream temperature and stream discharge (Equation 2), it had an Akaike weight of 0.09 (Table 22) and an adjusted $R^{2}$ of 0.83 .

\section{Discussion}

The annual average leaf litter breakdown rate was suppressed in both AP streams and AMD streams. The average decomposition rate of AP streams was reduced by $53 \%$ compared to $\mathrm{CN}$ streams. The average decomposition rate of AMD streams was reduced by $70 \%$ compared to $\mathrm{CN}$ streams. The range of decomposition rates $(0.002-0.025 \mathrm{~g} /$ day $)$ found in our study agrees with those from another decomposition study examining an AMD gradient (Niyogi et al. 2001). The reduction of leaf litter breakdown rate seen in our AMD streams were within the range of reductions reported in AMD streams by Gessner and Chauvet (2002). However, the reduction in breakdown rates seen in our AP streams was considerably larger than those reported (30\%) in AP streams by Gessner and Chauvet (2002).

Young et al. (2008) set up a tentative frame work for assessing functional stream integrity from leaf litter breakdown rates, they considered break down rates between $0.01-0.03$ g/day to indicate streams of good health. All but one of the breakdown rates from our CN streams fell within this range. Young et al. (2008) and Gessner and Chauvet (2002) set a

threshold of breakdown rates $<50 \%$ of reference streams to indicate severe impairment. All of 
the breakdown rates from our AMD streams were well below this threshold. Three of the five breakdown rates from our AP streams would be considered severely impaired.

The water chemistries of our study sites fell neatly into previously established water quality types (Merovich et al. 2007). Principal components analysis mapped study streams along two gradients. The first gradient separated AMD sites from $\mathrm{CN}$ and AP streams along a principal component with water chemistries variables indicative of acid mine drainage contamination including $\mathrm{pH}$, alkalinity, acidity, conductivity, dissolved metals, and sulfate (Freund and Petty 2007, Merovich et al. 2007). AMD sites were mapped at high values along this principal component and had water chemistries that corresponded with streams classified as severe AMD by Merovich et al. (2007). Given the water chemistries of these sites it is highly probable that these streams drain intensively mined watersheds with prolific acid producing minerals having little to no geologic buffering capacity or chemical treatment (Merovich et al. 2007).

The second gradient separated AP streams from CN streams along a principal component with water chemistries variables symptomatic of streams suffering from acid precipitation including alkalinity, acidity, Ca and $\mathrm{Na}$ (Freund and Petty 2007, Merovich et al. 2007). AP sites consistently mapped higher along this second gradient, and had water chemistries that resembled streams classified as soft by Merovich et al. (2007). Given the water chemistries of these sites it is highly probable that these AP streams drained a watershed with no mining but received high acid precipitation and have little to no geological potential for acid neutralization (Merovich et al. 2007). CN streams mapped low along both principal components, where $\mathrm{pH}$ and alkalinity were relatively high, and where acidity, conductivity, sulfate and dissolved metals were low. The water chemistry of $\mathrm{CN}$ streams matched streams classified as reference by Merovich et al. (2007), leading to the conclusion that these streams 
drained un-mined watersheds that contained geologic attributes capable of buffered any acid precipitation (Merovich et al. 2007).

Through our study design we were able to control for discharge in our study streams. All types contained streams with roughly equal drainage areas and discharge. However, there was some variation in stream temperature between the stream types with AMD streams having a higher annual average temperature than $\mathrm{CN}$ and $\mathrm{AP}$ streams. This variation in stream temperature was not factored out for analyses, because other studies (Simon et al. 2009, Fritz et al. 2010) of leaf litter breakdown in Appalachian streams concluded that stream temperature was not a relevant variable influencing leaf litter breakdown rate. Simon et al. (2009) found that neither stream temperature nor discharge explained variation in leaf litter breakdown rates. Fritz et al. (2010) found that difference in thermal regime was not a primary driver of leaf litter breakdown rate. Our results concur that stream temperature was not a contributing factor in differences in leaf litter breakdown rates, as there was no positive relationship between stream temperature and leaf litter breakdown rates for any of the stream types.

As expected, stream macroinvertebrate communities were similar within stream types but differed between the types. $\mathrm{CN}$ communities were associated with low concentrations of dissolved metals, sulfate and conductivity and relatively high $\mathrm{pH}$. AP communities were associated with low $\mathrm{pH}$ but with dissolved metals, sulfate and conductivities even lower than $\mathrm{CN}$ streams. AMD communities were all associated with extremely low $\mathrm{pH}$ and the majority of assemblages were associated with high conductivity, sulfate and dissolved metals. These groupings and associations agree with the notion that macroinvertebrate assemblages respond in a predictable fashion to variation in water chemistry (Freund and Petty 2007).

Macroinvertebrate assemblages in AMD streams were highly variable when compared to the assemblages of $\mathrm{CN}$ and AP streams. All AMD assemblages had two things in common: 
there were very few individuals found in these streams and Chironomidae almost completely dominated those macroinvertebrates found. This explains why AMD assemblages were associated with a high percent dominant metric. The variation in AMD communities comes from the few individuals from other taxa found in these streams. CN community assemblages were associated with high WVSCI scores, family richness and EPT richness, AP streams had community assemblages with reduced WVSCI scores, family richness and EPT richness, and AMD assemblages had extremely low WVSCI scores, family richness and EPT richness. We saw a progressive decline in WVSCI score and EPT richness as chemical stressors increased indicating that macroinvertebrate assemblages are reliable indicators of environmental integrity.

Invertebrate communities may be altered by stream chemistries due to impaired osmoregulation, metal toxicity, reduced reproductive success and altered behaviors (Pond et al. 2008). Macroinvertebrates may suffer physiological stress to increased acidity through interruptions in their ion exchange mechanisms leading to a cellular acid base imbalance or failure in salt regulation (Hall et al. 1980). Metal exposure also affects benthic macroinvertebrate composition and abundance (Cain et al. 2000, Niyogi et al. 2001). For example iron precipitation and flocculation accumulating on surfaces in AMD streams can have direct effect on invertebrates through toxicity and indirect effects on stream invertebrates by inhibiting movement, respiration and feeding and by altering the benthic environment (Vuori 1995, Fritz et al. 2010). The effects of iron contamination are known to decrease the diversity and abundance of benthic invertebrates (Vuori 1995). Acute toxicity levels for iron in invertebrates ranged from 3-400mg/L (Vuori 1995). Iron concentrations in the AMD streams for this study were around $20 \mathrm{mg} / \mathrm{L}$ but remained under $0.5 \mathrm{mg} / \mathrm{L}$ in both AP and CN streams. Conductivities over $500 \mu \mathrm{S} / \mathrm{cm}$ are also known to hinder macroinvertebrate communities (Hartman et al. 2005). Conductivities in the AMD stream in this study were consistently well 
above $500 \mu \mathrm{S} / \mathrm{cm}$. Also, many dilute stressors can interact to produce biological impairment even if each stressor is below toxicity thresholds (Freund and Petty 2007)

Shredder community assemblages varied between the three stream types. The stoneflies Nemouridae and Leuctridae, which dominated AP streams and were found in low quantities in AMD streams, are considered acid tolerant (Hall et al. 1980, Dangles and Guerold 2001, McClurg et al. 2007). The reduction in predators and competitors in acidic streams may have allowed these taxa tolerant to low $\mathrm{pH}$ to increase in abundance and become the dominant organisms (Hall et al. 1980). Lepidostoma, which contributed to the shredder assemblage in CN streams, was considered acid sensitive by a number of previous studies (Raddum and Fjellheim 2003, McClurg et al. 2007, Simon et al. 2009). However Lepidostoma were found in three of our AP streams. Gammarus, which were found in all CN streams and completely dominated some of the shredder assemblages, are acid sensitive and were also found to dominate neutral streams by Dangles and Guerold (2001). While Limnephilidae were found in acidic streams by Dangles and Guerold (2001), we only found Limnephilidae in CN streams in our study. Although Tipulidae did not contribute largely to any shredder assemblage their numbers did not significantly vary between the streams types contrary to the findings of Hall et al. (1980) who documented a reduction in Tipulidae numbers after artificial acidification of a stream.

Different species of the same functional group can vary in their relative importance to an ecological process, as they may differ in the way or rate in which they perform the process (Dangles and Guerold 2001). For example, the consumption of leaf material by the same size and number of individual Nemouridae was significantly lower than Gammarus in a feeding experiment (Dangles and Guerold 2001). Also, Nemouridae act as collectors rather than shredders in their younger stage (Dangles and Guerold 2001). Limnephilidae have been documented to be more voracious leaf processors than stoneflies, and their abundance was 
associated with shredder mediated leaf litter decomposition in a study by Mckie et al. (2006). Lepidostoma are also known to play an important role in leaf litter processing (Wallace et al. 1996) and were highly related to decomposition in a study by Simon et al. (2009). The exclusion of Decopoda in a study by Schofield et al. (2001) led to a reduction in leaf litter breakdown despite the presence of other highly productive shredders. Pteronarcyidae presence has also been attributed to faster leaf litter breakdown rates (Schofield et al. 2001). Therefore, the reduction in shredder evenness and the eradication of the acid sensitive voracious shredder could be an important factor explaining the reduction of leaf litter breakdown even if they are replaced with acid tolerant stoneflies in greater numbers (Dangles and Guerold 2001, Hieber and Gessner 2002, Dangles et al. 2004, Mckie et al. 2006)

When present, shredders have an important effect on breakdown rates in both pristine and AMD impacted streams (Niyogi et al. 2001). In this study we found that total shredder abundance was not related to decomposition rate. Nor was the number of shredding Plecoptera, number of shredding Tipulidae, or number of shredding Nemouridae. The lack of relationship between shredder abundance and breakdown rate was likely a result of Nemouridae stoneflies dominating the shredder assemblage in AP streams.

In this study shredder richness was not correlated with decomposition overall but there were trends between shredder richness and decomposition rate in AP and CN streams. Other studies found that while an increase in shredder biomass may or may not be related to leaf litter breakdown, increasing taxonomic richness of shredders were positively related to litter breakdown (Huryn et al. 2002, Dangles et al. 2004, Fritz et al. 2010). It is suspected by Huryn et al. (2002) that high shredder richness leads to higher leaf litter consumption efficiency as a result of different modes of feeding within the shredder functional feeding group (e.g., whole leaf consumption by some Tipulidae vs. leaf skeletonisation by many stoneflies). However, as we did not see an overall relationship between shredder richness and decomposition, it suggests 
that there may be a degree of redundancy among shredder taxa inhabiting headwater streams (Huryn et al. 2002).

We found that the number of shredding Trichoptera was related to decomposition rate. It has been indicated that the loss of a particular group of sensitive taxa with high shredding capacity may be the primary cause of reduced leaf litter breakdown under acidic conditions (Dangles and Guerold 2001, Simon et al. 2009). As there are a number of highly efficient shredding Trichoptera the relationship between reduction of shredding Trichoptera and decomposition suggests that there is limited redundancy in taxa that sustain high levels of leaf litter breakdown (Lake et al. 2007).

$\mathrm{CN}$ streams with the highest rate of decomposition had most if not all of the high efficiency shredders present (Lepidostoma, Limnephilidae, Pteronarcys, Gammarus, and Decopoda). AP streams with reduced decomposition had only one or two of these taxa present (Appendix I.). This indicates that the specific sequence of taxa loss due to environmental stressors must be taken into account when assessing the consequences of taxa losses resulting from environmental change (Dangles et al. 2004).

In this study we found that microbial activity was greatest in $\mathrm{CN}$ streams. We noted that ergosterol concentration was inhibited in AMD streams and total microbial respiration was depressed in both AP and AMD streams. A study by Simon et al. (2009) found that microbial respiration was positively related with $\mathrm{pH}$. A study by Suberkropp and Chauvet (1995) found that alkalinity and $\mathrm{pH}$ had a major effect on fungal communities colonizing leaves. Leaves collected in acidic streams by Hall et al. (1980) had fewer fungal spores. Several studies of the impacts of mine drainage on streams found slower microbial activity with increasing levels of metal concentration and precipitates (Bermingham et al. 1996, Schliet et al. 2004, Barnden and Harding 2005, Fritz et al. 2010), with some streams of low pH exhibiting high microbial 
respiration rates (Niyogi et al. 2001). Hyphal cover of leaves was likely reduced in our AMD streams, as iron plaques probably hindered leaf accessibility to microbes (Bermingham et al. 1996, Schliet et al. 2004).

We found that ergosterol concentration and total microbial respiration were positively associated with decomposition rate. Several other studies found that microbial activity was positively associated with leaf litter breakdown rates (Dangles et al. 2004, Mckie et al. 2006, Simon et al. 2009). However, not all studies have found a relationship between ergosterol and leaf litter breakdown (Fritz et al. 2010). The reduction in leaf decomposition in AMD sites that was observed may be due to changes in metabolic activity of the fungal assemblage on leaves as suggested by Bermingham et al. (1996).

We saw that differences in leaf litter break down was most strongly related to microbial activity, as was seen by other studies (Suberkropp and Chauvet 1995, Bermingham et al. 1996, Pascoal et al. 2001). However, as seen in other studies (Dangles et al. 2004, Fritz et al. 2010) it is likely the combination of differences in shredder assemblage and microbial activity that drive the changes in leaf litter breakdown rates. Reduction in leaf litter breakdown rate in AMD streams was likely a result of severe reduction or loss of the shredder assemblage, reduction in microbial activity, and mineral encapsulation of organic matter limiting access. Reduction in leaf litter breakdown rates in AP streams was likely a result of the shift in shredder community to small facultative acid tolerant shredders from more voracious shredders, and a reduction in microbial activity. This study supports that stressors caused by acid precipitation and acid mine drainage led to reductions in shredder function and microbial activity resulting in more unprocessed leaf litter accumulating in streams and a reduction in the release and export of fine particulate organic matter, dissolved organic matter and nutrients, as noted by Hall et al. (1980) and Wallace et al. (1996) 
Decomposition rate was not highly correlated with any of the macroinvertebrate metrics measured. However, EPT richness and family richness were the most correlated with leaf litter breakdown rates. There is some evidence suggesting that for the shredding of coarse particulate organic matter the effectiveness of the functional group increases with the addition of further species (Lake et al. 2007). However, all species are not equal in terms of ecosystem function; this is an important consideration in selecting indicator taxa, as those that provide important links in food web should be a crucial criterion (Bunn and Davies 2000).

Standard bioassessment procedures offer evidence that changes in water quality affects the community structure of stream invertebrates; however, how changes in community structure translate into changes in stream ecosystem function is not indicated (Bunn et al. 1999, Huryn et al. 2002). Leaf breakdown rates do not necessarily reflected biotic conditions as assessed by biotic indices (Pascoal et al. 2001). This would suggest that both data from structural and functional aspects of a stream are critical in assessing water quality. There are several advantages of using leaf litter breakdown rate as an indicator of stream health. One advantage is that measuring leaf litter breakdown rate is simple and requires inexpensive and readily available equipment. Another is that many studies have examined factors controlling leaf litter breakdown, so it will respond to variation caused by stressors in a predictable way. Additionally, leaf breakdown can be measured in any aquatic habitat (Young et al. 2008). There are also a few disadvantages in using leaf litter breakdown as a measure of stream health. One disadvantage is that leaf litter breakdown is influenced by a wide variety of factors so interpretation of results is sometimes difficult. Another disadvantage is that leaf litter breakdown is only indicative of the conditions at a specific location within a stream rather than a whole reach. An additional disadvantage is that the significance of leaf litter breakdown is not intuitive to the general public (Young et al. 2008). Assessment of ecosystem function is important in making decisions on restoration potential (Ryder and miller 2005, Davies and Jackson 2006), as 
many goals relating to management and protection of streams refer to ecosystem processes (Bunn and Davies 2000). Breakdown reflects the total energetic functionality of stream ecosystems (Braioni et al. 2004) and this ecosystem measurement integrates factors at a large spatial scale which allows the health of a stream to be viewed in a catchment context (Bunn et al. 1999).

Acid stream restoration may produce ecological benefits by increasing localized processing of organic matter and the down-stream delivery of fine particulate organic matter and invertebrate biomass. There is also a potential for increased nutrient uptake if microbial activity is increased (Hamilton et al. 2001). Acid remediation can provide other benefits such as increased fish and macroinvertebrate diversity and the reestablishment of trout fisheries (McClurg et al. 2007). The reduction of acidity has the potential to partially restore organic matter processing by increasing shredder biomass (McClurg et al. 2007) and increasing the abundance of some acid sensitive key shredders (Simon et al. 2009). However, liming of acidic streams has had varying success in restoring leaf litter decomposition. A study by Merrix et al. (2006) found that liming restored decomposition rates to those of non-acidic streams, while a study by Mckie et al. (2006) found that liming increased leaf litter breakdown by microbes but reduced shredding invertebrates. A study by McClurg et al. (2007) found that while shredder biomass was restored to levels comparable to neutral streams many of the key shredders were not restored. It was suggested that the lack of response of the macroinvertebrate community to liming treatment was a result of highly variable water chemistry downstream of treatment sites due to a resulting mixing zone where metals precipitate out of solution and increased sedimentation may occur (McClurg et al. 2007). Also, any remediation plan for AMD streams must decrease dissolved metal concentrations below the threshold for survival of shredding invertebrates, while at the same time preventing high rates of metal oxide deposition, which will limit both shredders and microbes (Niyogi et al. 2001). 


\section{Literature Cited}

Barbour, M. T., J. Gerritsen, B. D. Snyder, and J. B. Stribling. 1999. Rapid bioassessment protocols for use in streams and wadeable rivers: periphyton, benthic macroinvertebrates, and fish. 2nd edition. EPA 841-B-99-022. Office of Water, US Environmental Protection Agency, Washington,DC.

Barnden, A.R. and J.S. Harding, 2005. Shredders and leaf breakdown in streams polluted by coal mining in the south island, New Zealand. New Zealand Natural Science 30: $35-48$

Benfield, E.F. 1996. Leaf breakdown in stream ecosystems. in Methods in Stream Ecology F.R. Hauerand G.A. Lambert (editors). Academic Press, San Diego, California.

Bermingham, S., L. Maltby, and R.C. Cooke. 1996. Effects of a coal mine effluent on aquatic hypomycetes. I. Field study. Journal of Applied Ecology 33: 1311-1321

Braioni, M.G., M.D. Cortivo, and G. Salmoiraghi. 2004. Leaf litter breakdown processing in the functional monitoring of a mountain stream. International Review of Hydrobiology 89: 536-550

Bunn, S.E. and P.M. Davies. 2000. Biological processes in running waters and their implications for the assessment of ecological integrity. Hydrobiologia 422/423: 61-70 
Bunn, S.E., P.M. Davie, and T.D. Mosisch. 1999. Ecosystem measures of river health and their response to riparian and catchment degradation. Freshwater Biology 41: $333-345$

Burnham, K.P., and D.R. Anderson. 2002. Model Selection and Multimodel Inference A Practical Information-Theoretic Approach. Second edition. Springer-Verlag. New York, New York

Cain, D.J., J.L. Carter, S.V. Fend, S.N. Luoma, C.N. Alpers, and H.E. Taylor. 2000. Metal exposure in a benthic macroinvertebrate, Hydropsyche califrnica, related to mine drainage in the Sacramento River. Canadian Journal of Fisheries and Aquatic Science 57: $380-390$

Clarke, K.R. 1993. Non-parametric multivariate analyses of changes in community structure. Australian Journal of Ecology 18: 117-143

Clarke, K.R., and R.H. Green. 1988. Statistical design and analysis for a "biological effects" study. Marine Ecology Progress Series 46: 213-226

Dangles, O. and F. Guerold, 2001. Linking shredders and leaf litter processing: insights from an acidic stream study. International Review of Hydrobiology 86: 395-406

Dangles, O., M.O. Gessner, F. Guerold, and E. Chauvet. 2004. Impact of stream acidification on litter breakdown: implications for assessing ecosystem functioning. Journal of Applied Ecology 41: 365-378 
Davies, S.P., and S.K. Jackson. 2006. The biological condition gradient: a descriptive model for interpreting change in aquatic ecosystems. Ecological Applications 16: 1251-1266

EPA. 1991. Methods for the determination of metals in environmental samples. EPA 600-91010. United States Environmental Protection Agency Office of Research and Development, Washington DC, 20460.

Fisher, S.G., N.B. Grimm, E. Marti, R.M. Holmes, and J.B. Jones. 1998. Material spiraling in stream corridors: a telescoping ecosystem model. Ecosystems 1: $19-34$

Freda, J. 1986. The influence of acidic pond water on Amphibians: a review. Water, Air and Soil Pollution 30: 439-450

Freund, J. G. and J. T. Petty. 2007. Response of fish and macroinvertebrate bioassessment indices to water chemistry in a mined Appalachian watershed. Environmental Management 39:707-720.

Fritz, K.M., S. Fulton, B.R. Johnson, C. B. Barton, J.D. Jack, D.A. Word, and R.A. Burke. 2010. Structural and functional characteristics of natural and constructed channels draining a reclaimed mountaintop removal and valley fill coal mine. Journal of North American Benthological Society 29: 673-689

Gessner, M.O. and E. Chauvet. 2002. A Case for using litter breakdown to assess functional stream integrity. Ecological Applications 12: 498-510 
Gingerich, R.T. 2010. Plant litter decomposition in mitigated and reference wetlands. M. S. Thesis, West Virginia University, Morgantown, West Virginia

Hair, J.F., R.E. Anderson, R.L. Tatham, and W.C. Black. 1995. Multivariate Data Analysis with Readings. Prentice Hall, Upper Saddle River, NJ, USA

Hall, R.J., G.E. Likens, S.B. Fiance, and G.R. Hendrey. 1980. Experimental acidification of a stream in the Hubbard Brook Experimental Forest, Hew Hampshire. Ecology 61: $976-989$

Hamilton, S.K., J.L. Tank, D.F. Raikow, W.M. Wollheim, B.J. Peterson, and J. R. Webster. 2001. Nitrogen uptake and transformation in a midwestern U.S. stream: A isotope enrichment study. Biogeochemistry 54: 297-340

Hartman, K. J., J.D. Kaller, J. W. Howell, and J. A. Sweka. 2005. How much do valley fills influence headwater streams? Hydrobiologia 532: 91-102.

Hieber M., and M.O. Gessner. 2002. Contribution of stream detritivores, fungi, and bacteria to leaf breakdown based on biomass estimates. Ecology 83:1026-1038

Huryn, A.D., V. M. Huryn, C.J. Arbuckle, and L. Tsomides. 2002. Catchment land-use, macroinvertebrate and detritus processing in headwater streams: taxonomic richness versus function. Freshwater Biology 47: 401-415 
Hutchens, J.J., and J.B. Wallace. 2002. Ecosystem linkages between southern Appalachian headwater streams and their banks: leaf litter breakdown and invertebrate assemblages. Ecosystems 5: 80-91

Karr, J.R. 1999. Defining and measuring river health. Freshwater Biology 41: 221-234

Kuehn K.A., M.J. Lemke, K. Suberkropp, and R.G. Wetzel. 2000. Microbial biomass and production associated with decaying leaf litter of the emergent macrophyte Juncus effusus. Limnology and Oceanography 45:862-870

Lake, P.S., N. Bond, and P. Reich. 2007. Linking ecological theory with stream restoration. Freshwater Biology 52: 597-615

LeFevre, S.R., and W.E. Sharpe. 2002. Acid stream water remediation using limestone sand on Bear Run in southwestern Pennsylvania. Restoration Ecology 10: 223-236

McClurg, S.E., J.T. Petty, P.M. Mazik, and J.L. Clayton. 2007. Stream ecosystem response to limestone treatment in acid impacted watersheds of the Allegheny Plateau. Ecological Applications. 17: 1087-1104

McCune, B., and J.B. Grace. 2002. Analysis of ecological communities. MjM Software Design, Gleneden Beach, Oregon.

Mckie, B.G., Z. Petrin, and B. Malmqvist. 2006. Mitigation or disturbance? Effects of liming on macroinvertebrate assemblage structure and leaf-litter decomposition in the humic streams of northern Sweden. Journal of Applied Ecology 43: 780-791 
Merovich, G.T., J.M. Stiles, J.T. Petty, P.F. Ziemkiewicz, and J.B. Fulton. 2007. Water chemistry-based classification of streams and implications for restoring mined Appalachian watersheds. Environmental Toxicology and Chemistry 26: $1361-1369$

Merovich, G. T., and J. T. Petty. 2007. Interactive effects of multiple stressors and restoration priorities in a mined Appalachian watershed. Hydrobiologia 575:13-31.

Merovich, G.T., and J.T. Petty. 2010. Continuous response of benthic macroinvertebrate assemblages to a discrete disturbance gradient: consequences for diagnosing stressors. Journal of North American Benthological Society 29: 1241-1257

Merritt, R.W., and Cummins, K.W. 1996. An Introduction to the Aquatic Insects of North America. Third edition. Kendall and Hunt, Dubuque, lowa.

Merrix, F.L., B.R. Lewis, and S.J. Ormerod. 2006. The effects of low pH and palliative liming on beech litter decomposition in acid-sensitive streams. Hydrobiologia 571: 373-381

Newell, S.Y., T.L. Arsuffi, and R.D. Fallon. 1988. Fundamental procedures for determining ergosterol content of decaying plant material by liquid chromatography. Applied and Environmental Microbiology 54: 1876-1879

Niyogi, D.K., W.M. Lewis, Jr, and D.M. McKnight. 2001. Litter breakdown in mountain streams effected by mine drainage: biotic mediation of abiotic controls. Ecological Applications 11: $506-516$ 
Niyogi, D.K., D.M. Mcknight, and W.M. Lewis. 2002. Effects of mine drainage on breakdown of aspen litter in mountain streams. Water, Air, and Soil Pollution 2: 329-341

Oksanen, J., R. Kindt, P. Legendre, B. O’Hara, G. L. Simpson, P. Solymos, H. Henry, H. Stevens, and H. Wagner. 2008. vegan: Community Ecology Package. R package version 1.15-0.

Panaccione, D. G. \& C. M. Coyle. 2005. Abundant respirable ergot alkaloids from the common airborne fungus Apergillus fumigatus. Applied and Environmental Microbiology 71: $3106-3111$.

Pascoal, C., F. Cassio, and P. Gomes, 2001. Leaf breakdown rates: a measure of water quality. International Review of Hydrobiology. 86: 407-416

Pascoal, C., M. Pinho, F. Cassio, and P. Gomes. 2003. Assessing structural and functional ecosystem condition using leaf breakdown: studies on a polluted river. Freshwater Biology 48: 2033-2044

Peckarsky, B. L., P. R. Fraissinet, M. A. Penton, and J. Conklin, D. J. 1990. Macroinvertebrates of Northeastern North America. Cornell University Press, Ithaca.

Petty, J.T., J.B. Fulton, M.P. Strager, G.T. Merovich, J.M. Stiles, and P.F. Ziemkiewicz. 2010. Landscape indicators and thresholds of stream ecological impairment in an intensively mined Appalachian watershed. Journal of North American Benthological Society 29:1292-1309 
Petty, J. T., and D. Thorne. 2005. An ecologically based approach to identifying restoration priorities in an acid impacted watershed. Restoration Ecology 13:348-357

Pond. G. J., M. E. Passmore, F. A. Borsuk, L. Reynolds, and C. J. Rose. 2008. Downstream effects of mountaintop coal mining: comparing biological conditions using family-and genus-level macroinvertebrate bioassessment tools. Journal of the North American Benthological Society 27(3):717-737.

Raddum, G.G., and A. Fjellheim. 2003. Liming of river Audna, southern Norway: a large-scale experiment of benthic invertebrate recovery. Ambio 32: 230-234

Richardson, M. D., and S. Logendra. 1997 Ergosterol as an indicator of endophyte biomass in grass seeds. Journal of Agricultural and Food Chemistry 45: 3903-3907.

Roberts, D. W. 2007. labdsv: Ordination and Multivariate Analysis for Ecology. R package version 1.3-1.

Royer, T.V., and G.W. Minshall. 2003. Control of leaf processing in streams from spatial-scaling and hierarchical perspectives. Journal of the North American Benthological Society 22:352-358

Ryder, D.S., and W. Miller. 2005. Setting goals and measuring success: linking patterns and processes in stream restoration. Hydrobiologia 552: 147-158

Schlief, J. 2004. Leaf associated microbial activities in a stream affected by acid mine drainage. International Review of Hydrobiology 89: 467-475 
Schlief, J., and M. Mutz. 2006. Palatability of leaves conditioned in streams affected by mine drainage: a feeding experiment with Gammarus pulex (L.). Hydrobiologia 563: $445-452$

Schofield, K.A., C.M. Pringle, J.L. Meter, and A. B. Sutherland. 2001. The importance of crayfish in the breakdown of rhododendron leaf litter. Freshwater Biology 46: 1191-1204

Simon, K.S., M.A. Simon, and E.F. Benfield. 2009. Variation in ecosystem function in Appalachian streams along an acidity gradient. Ecological Applications 19: $1147-1160$

Suberkropp, K., and E. Chauvet. 1995. Regulation of leaf breakdown by fungi in streams: influences of water chemistry. Ecology 76: 1433-1445

Tetra Tech, Inc. 2000. A stream condition index for West Virginia wadeable streams. Owing Mills, MD

Vuori, K.M. 1995. Direct and indirect effects of iron on river ecosystems. Annual Zoological Finnish 32: 317-329

Wallace, J.B., J.W. Grubaugh, and M.R. Whiles. 1996. Biotic indices and stream ecosystem processes: results from an experimental study. Ecological Applications 6: $140-151$ 
Ward, A. K. and Johnson, M. D. 1996. "Heterotrophic Microorganisms," in Methods in Stream Ecology, F. R. Hauer and G. A. Lamberti, (editors) San Diego, California.

Webster, J.R., E.F. Benfield, T.P. Ehrman, M.A. Schaeffer, J.T. Tank, J.J. Hutchens, and D.J. D'Angelo. 1999. What happens To allochthonous material that falls into streams? A synthesis of new and published information from Coweeta. Freshwater Biology 41: 687-705

Wider, R.K., and G.E. Lang. 1982. A critique of the analytical methods used in examining decomposition data obtained from litter bags. Ecology 63: $1636-1642$

Wipfli, M.S., J.S. Richardson, and R.J. Naiman. 2007. Ecological linkages between headwaters and downstream ecosystems: transport of organic matter, invertebrates, and wood down headwater. Journal of the American Water Resources Association 43: $72-85$

WVDEP. 1996. An ecological assessment of the Cheat River watershed. Report Number 0502004-1996. West Virginia Division of Environmental Protection Charleston, WV.

WVDEP. 2003. Benthic invertebrate sampling, processing, and analysis standard operating procedures. West Virginia Division of Environmental Protection.

Young, R.G., C.D. Matthaei, and C.R. Townsend. 2008. Organic matter breakdown and ecosystem metabolism: functional indicators for assessing river ecosystem health. Journal of North American Benthological Society 27: 605-62 
Table 1: Classifications of some distinguishing water chemistry parameters

\begin{tabular}{lccccc}
\hline & Extremely low & Low & Moderate & High & $\begin{array}{c}\text { Extremely } \\
\text { high }\end{array}$ \\
\hline $\mathrm{pH}$ & $2-4.5$ & $4.5-6.5$ & $6.5-7.5$ & -- & -- \\
$\mathrm{SpC}(\mu \mathrm{S} / \mathrm{cm})$ & $0-20$ & $20-60$ & $60-500$ & $500-1000$ & $>1000$ \\
$\mathrm{Alk}(\mathrm{mg} / \mathrm{L})$ & $0-1$ & $1-5$ & $10-60$ & -- & -- \\
$\mathrm{Ca}(\mathrm{mg} / \mathrm{L})$ & $0-4$ & $4-10$ & $10-30$ & $30-100$ & $>100$ \\
$\mathrm{Mg}(\mathrm{mg} / \mathrm{L})$ & $0-1$ & $1-5$ & $5-10$ & $10-50$ & $>50$ \\
$\mathrm{SO}(\mathrm{mg} / \mathrm{L})$ & $0-10$ & $10-50$ & $50-100$ & $100-500$ & $>500$ \\
$\mathrm{Fe}(\mathrm{mg} / \mathrm{l})$ & $0-0.5$ & $0.5-1$ & $1-3$ & $3-20$ & $>20$ \\
$\mathrm{Mn}(\mathrm{mg} / \mathrm{L})$ & $0-0.5$ & $0.5-1$ & $1-3$ & $3-10$ & $>10$ \\
\hline
\end{tabular}


Table 2: Location, acid contaminating type, and general characteristics of 15 study streams.

\begin{tabular}{|c|c|c|c|c|c|c|c|c|}
\hline Site & Stream name & Latitude & Longitude & Stream type & $\begin{array}{l}\text { Drainage } \\
\text { area }\left(\mathrm{km}^{2}\right)\end{array}$ & $\begin{array}{l}\text { Average stream } \\
\text { temperature }\left({ }^{\circ} \mathrm{C}\right)\end{array}$ & $\begin{array}{l}\text { Average } \\
\text { discharge }\left(\mathrm{m}^{3} / \mathrm{s}\right)\end{array}$ & Slope (\%) \\
\hline CN 1 & Darnell Hollow & 39.686380 & -79.792680 & circumneutral & 1.62 & 10.38 & 0.10 & 4.60 \\
\hline CN 2 & UNT of Muddy & 39.569156 & -79.528956 & circumneutral & 2.71 & 10.43 & 0.13 & 6.71 \\
\hline CN 3 & Roaring & 39.526080 & -79.556000 & circumneutral & 5.67 & 10.31 & 0.46 & 6.72 \\
\hline CN 4 & Daughtery & 39.495700 & -79.575380 & circumneutral & 4.79 & 10.43 & 0.23 & 7.38 \\
\hline CN 5 & Muddy & 39.563361 & -79.532803 & circumneutral & 9.46 & 10.39 & 0.28 & 7.09 \\
\hline AP 1 & Jumprock R & 39.589990 & -79.552390 & acid precipitation & 4.64 & 10.37 & 0.11 & 8.49 \\
\hline AP 2 & Lick of Roaring & 39.543069 & -79.587117 & acid precipitation & 6.79 & 10.37 & 0.36 & 6.72 \\
\hline AP 3 & Little Laurel Cr. & 39.678892 & -79.746828 & acid precipitation & 2.58 & 9.97 & 0.09 & 5.34 \\
\hline AP 4 & Little Laurel R & 39.677383 & -79.749736 & acid precipitation & 2.75 & 9.86 & 0.12 & 7.54 \\
\hline AP 5 & Sugarcomb & 39.589422 & -79.545417 & acid precipitation & 4.37 & 10.24 & 0.16 & 6.37 \\
\hline AMD 1 & Fickey & 39.551020 & -79.637440 & acid mine drainage & 4.29 & 11.73 & 0.12 & 3.43 \\
\hline AMD 2 & Glade & 39.552360 & -79.647710 & acid mine drainage & 9.88 & 11.21 & 0.44 & 5.33 \\
\hline AMD 3 & Martin & 39.547364 & -79.644430 & acid mine drainage & 14.11 & 11.15 & 0.53 & 6.87 \\
\hline AMD 4 & S. Fork Greens & 39.483310 & -79.675360 & acid mine drainage & 5.08 & 12.08 & 0.16 & 5.89 \\
\hline AMD 5 & UNT of Glade & 39.569589 & -79.654089 & acid mine drainage & 1.93 & 11.45 & 0.08 & 5.33 \\
\hline
\end{tabular}

$\mathrm{CN}=$ circumneutral, $\mathrm{AP}=$ acid precipitation, and $\mathrm{AMD}=$ acid mine drainage 
Table 3: Mean $( \pm \mathrm{SE})$ drainage area, annual average discharge, slope, and annual average stream temperature for each stream type. F-values come from ANOVAs of each variable $($ d.f. $=2)$

\begin{tabular}{|c|c|c|c|c|}
\hline \multirow{3}{*}{$\frac{\text { Physical parameters }}{\text { Drainage area }\left(\mathrm{Km}^{2}\right)}$} & \multicolumn{3}{|c|}{ Stream type } & \multirow[b]{2}{*}{ F-value } \\
\hline & $\frac{\text { Circumneutral }}{(n=5)}$ & $\frac{\text { Acid precipitation }}{(n=5)}$ & $\frac{\text { Acid mine drainage }}{(n=5)}$ & \\
\hline & $4.85^{\mathrm{a}}(1.36)$ & $4.23^{a} \quad(0.76)$ & $7.06^{\mathrm{a}}(2.19)$ & $0.92^{\mathrm{NS}}$ \\
\hline Discharge $\left(\mathrm{m}^{3} / \mathrm{s}\right)$ & $(0.10)$ & $(0.05)$ & (0.09) & $0.75^{\mathrm{NS}}$ \\
\hline Slope (\%) & $(0.17)$ & $(0.52)$ & $(0.68)$ & $5.84^{*}$ \\
\hline Temperature ${ }^{\circ} \mathrm{C}$ & $10.71^{a b}$ & $10.17^{\mathrm{a}}$ & $11.53^{b}$ & $9.65^{\star *}$ \\
\hline
\end{tabular}


Table 4: Principle components analysis (PCA) results from average water chemistry over three seasons (summer, winter, and spring) of decomposition trials. PCA was used to verify stream type grouping.

\begin{tabular}{lcc}
\hline & PC1 & PC2 \\
\hline Eigenvalue & 10.91 & 1.67 \\
Total variance explained & 72.70 & 83.83 \\
\hline & & \\
Factors loading & & \\
$\mathrm{pH}$ & -0.86 & - \\
Conductivity & 0.94 & - \\
Alkalinity & -0.71 & -0.54 \\
Acidity & 0.65 & 0.46 \\
$\mathrm{Al}$ & 0.97 & - \\
$\mathrm{Ca}$ & 0.83 & -0.45 \\
$\mathrm{Cl}$ & 0.68 & - \\
$\mathrm{Co}$ & 0.89 & - \\
$\mathrm{Fe}$ & 0.89 & - \\
$\mathrm{Mg}$ & 0.94 & - \\
$\mathrm{Mn}$ & 0.96 & - \\
$\mathrm{Na}$ & 0.57 & -0.64 \\
$\mathrm{Ni}$ & 0.87 & - \\
$\mathrm{Zn}$ & 0.96 & - \\
$\mathrm{SO}$ & 0.94 & - \\
\hline
\end{tabular}


Table 5: Mean $( \pm \mathrm{SE})$ water chemistry parameters by site type for the summer decomposition trial. F-values come from ANOVAs of each water chemistry parameter (d.f. $=2)$.

\begin{tabular}{|c|c|c|c|c|c|c|c|}
\hline \multirow{3}{*}{$\begin{array}{l}\text { Chemical parameter } \dagger \\
\text { Discharge }\left(\mathrm{m}^{3} / \mathrm{s}\right)\end{array}$} & \multicolumn{6}{|c|}{ Stream type } & \multirow{3}{*}{$\frac{\text { F-value }}{3.1^{*}}$} \\
\hline & \multicolumn{2}{|c|}{$\frac{\text { Circumneutral }}{(n=5)}$} & \multicolumn{2}{|c|}{$\frac{\text { Acid precipitation }}{(n=5)}$} & \multicolumn{2}{|c|}{$\frac{\text { Acid mine drainage }}{(\mathrm{n}=5)}$} & \\
\hline & $0.05^{\mathrm{ab}}$ & $(0.01)$ & $0.03^{b}$ & $(0.01)$ & $0.07^{a}$ & $(0.02)$ & \\
\hline Temperature $\left({ }^{\circ} \mathrm{C}\right)$ & $13.77^{a}$ & $(0.57)$ & $13.74^{a}$ & $(0.48)$ & $15.72^{b}$ & $(0.42)$ & $5.3^{* *}$ \\
\hline $\mathrm{pH}$ & $7.14^{\mathrm{a}}$ & $(0.20)$ & $5.60^{b}$ & $(0.14)$ & $3.42^{c}$ & $(0.15)$ & $129.3^{* * *}$ \\
\hline $\mathrm{SpC}(\mu \mathrm{S} / \mathrm{cm})$ & $98.45^{\mathrm{a}}$ & (8.20) & $29.30^{\mathrm{a}}$ & $(1.03)$ & $1237.80^{b}$ & (126.57) & $85.8^{* * *}$ \\
\hline Alkalinity (mg/L) & $33.95^{\mathrm{a}}$ & (3.54) & $2.03^{b}$ & $(0.25)$ & $0.01^{b}$ & $(0.01)$ & $86.4^{\star * *}$ \\
\hline Acidity (mg/L) & $13.46^{\mathrm{a}}$ & $(9.86)$ & $14.57^{\mathrm{a}}$ & $(1.67)$ & $252.56^{\mathrm{b}}$ & $(47.83)$ & $23.8^{* * *}$ \\
\hline $\mathrm{Al}(\mathrm{mg} / \mathrm{L})$ & $0.10^{\mathrm{a}}$ & $(0.02)$ & $0.23^{a}$ & $(0.04)$ & $19.07^{\mathrm{b}}$ & $(2.57)$ & $54.0^{* * *}$ \\
\hline $\mathrm{Ba}(\mathrm{mg} / \mathrm{L})$ & $0.04^{\mathrm{a}}$ & $(0.01)$ & $0.04^{a}$ & $(0.00)$ & $0.02^{b}$ & $(0.00)$ & $6.45^{\star *}$ \\
\hline $\mathrm{Ca}(\mathrm{mg} / \mathrm{L})$ & $16.17^{a}$ & (1.91) & $2.05^{a}$ & $(0.13)$ & $113.01^{b}$ & $(11.13)$ & $85.7^{* * *}$ \\
\hline $\mathrm{Cl}(\mathrm{mg} / \mathrm{L})$ & $2.26^{\mathrm{a}}$ & $(0.21)$ & $1.05^{\mathrm{a}}$ & $(0.07)$ & $5.31^{\mathrm{b}}$ & $(1.18)$ & $10.1^{* * *}$ \\
\hline Co (mg/L) & $0.02^{a}$ & $(0.00)$ & $0.02^{a}$ & $(0.00)$ & $0.14^{b}$ & $(0.02)$ & $28.9^{* * *}$ \\
\hline $\mathrm{Cu}(\mathrm{mg} / \mathrm{L})$ & $0.02^{a}$ & $(0.00)$ & $0.02^{a}$ & $(0.00)$ & $0.02^{\mathrm{a}}$ & $(0.00)$ & $2.0^{\mathrm{NS}}$ \\
\hline $\mathrm{Fe}(\mathrm{mg} / \mathrm{L})$ & $0.18^{a}$ & $(0.03)$ & $0.22^{a}$ & $(0.03)$ & $27.39^{b}$ & (11.05) & $6.1^{\text {** }}$ \\
\hline $\mathrm{Mg}(\mathrm{mg} / \mathrm{L})$ & $1.82^{a}$ & $(0.13)$ & $0.86^{a}$ & $(0.04)$ & $46.65^{b}$ & (6.16) & $54.0^{* * *}$ \\
\hline $\mathrm{Mn}(\mathrm{mg} / \mathrm{L})$ & $0.09^{a}$ & (0.01) & $0.15^{\mathrm{a}}$ & $(0.03)$ & $5.96^{\mathrm{b}}$ & $(0.87)$ & $45.0^{* * *}$ \\
\hline $\mathrm{Na}(\mathrm{mg} / \mathrm{L})$ & $6.19^{a}$ & (1.27) & $5.21^{a}$ & $(1.25)$ & $11.71^{b}$ & (2.08) & $4.9^{*}$ \\
\hline $\mathrm{Ni}(\mathrm{mg} / \mathrm{L})$ & $0.02^{a}$ & $(0.00)$ & $0.03^{a}$ & $(0.01)$ & $0.19^{b}$ & $(0.03)$ & $25.1^{* * *}$ \\
\hline $\mathrm{Se}(\mathrm{mg} / \mathrm{L})$ & $0.05^{a}$ & $(0.00)$ & $0.05^{a}$ & $(0.00)$ & $0.05^{a}$ & $(0.00)$ & $0.2^{\mathrm{NS}}$ \\
\hline Zn (mg/L) & $0.02^{\mathrm{a}}$ & $(0.00)$ & $0.04^{a}$ & $(0.02)$ & $0.42^{b}$ & $(0.07)$ & $28.5^{\star \star \star}$ \\
\hline $\mathrm{SO}_{4}(\mathrm{mg} / \mathrm{L})$ & $10.91^{\mathrm{a}}$ & $(0.51)$ & $9.99^{a}$ & $(0.54)$ & $748.70^{b}$ & $(92.76)$ & $63.3^{* * *}$ \\
\hline TSS (mg/L) & $20.20^{a}$ & (4.93) & $26.60^{a}$ & $(15.41)$ & $32.45^{\mathrm{a}}$ & $(14.90)$ & $0.23^{\mathrm{NS}}$ \\
\hline PC1 & $-2.81^{a}$ & $(0.11)$ & $-2.48^{a}$ & $(0.20)$ & $5.17^{\mathrm{b}}$ & $(0.59)$ & $153.33^{* * *}$ \\
\hline PC2 & $2.38^{a}$ & $(0.31)$ & $-0.08^{a, b}$ & $(0.29)$ & $0.16^{\mathrm{b}}$ & $(0.19)$ & $29.33^{* * *}$ \\
\hline
\end{tabular}

Note: Parameters with the same lowercase superscript letter did not significantly differ among stream type $(p<0.1)$ ${ }^{*} p<0.1 \quad{ }^{* *} p<0.01 \quad{ }^{* * *} p<0.001 \quad$ NS, not significant.

† SpC, specific conductivity; TSS, total suspended solids; PC, principal component 
Table 6: Mean $( \pm \mathrm{SE})$ water chemistry parameters by site type for the winter decomposition trial. F-value from ANOVAs of each chemical parameter (d.f. $=2$ ).

\begin{tabular}{|c|c|c|c|c|c|c|c|}
\hline \multirow{3}{*}{$\begin{array}{l}\text { Chemical parameter } \dagger \\
\text { Discharge }\left(\mathrm{m}^{3} / \mathrm{s}\right)\end{array}$} & \multicolumn{6}{|c|}{ Stream type } & \multirow{3}{*}{$\frac{F \text {-value }}{0.2^{\text {NS }}}$} \\
\hline & \multicolumn{2}{|c|}{$\frac{\text { Circumneutral }}{(n=5)}$} & \multicolumn{2}{|c|}{$\frac{\text { Acid precipitation }}{(\mathrm{n}=5)}$} & \multicolumn{2}{|c|}{$\frac{\text { Acid mine drainage }}{(n=5)}$} & \\
\hline & $0.32^{\mathrm{a}}$ & $(0.1)$ & $0.23^{\mathrm{a}}$ & $(0.1)$ & $0.31^{a}$ & $(0.1)$ & \\
\hline Temperature $\left({ }^{\circ} \mathrm{C}\right)$ & $7.27^{\mathrm{a}}$ & (0.9) & $6.97^{\mathrm{a}}$ & (0.9) & $7.66^{\mathrm{a}}$ & (1.1) & $0.1^{\mathrm{NS}}$ \\
\hline $\mathrm{pH}$ & $6.44^{\mathrm{a}}$ & $(0.1)$ & $5.21^{\mathrm{b}}$ & $(0.2)$ & $4.09^{c}$ & $(0.1)$ & $89.4^{* * *}$ \\
\hline $\mathrm{SpC}(\mu \mathrm{S} / \mathrm{cm})$ & $74.59^{a}$ & (6.2) & $30.06^{a}$ & $(0.0)$ & $1026.15^{b}$ & $(113.0)$ & $42.9^{* * *}$ \\
\hline Alkalinity (mg/L) & $22.72^{\mathrm{a}}$ & $(3.0)$ & $1.93^{\mathrm{b}}$ & $(0.5)$ & $0.01^{b}$ & $(0.0)$ & $55.1^{* * *}$ \\
\hline Acidity (mg/L) & $70.36^{a}$ & $(19.0)$ & $86.86^{a}$ & (19.6) & $243.62^{b}$ & (35.3) & $13.3^{* * *}$ \\
\hline $\mathrm{Al}(\mathrm{mg} / \mathrm{L})$ & $0.15^{\mathrm{a}}$ & $(0.1)$ & $0.29^{a}$ & $(0.1)$ & $12.71^{\mathrm{b}}$ & $(2.1)$ & $31.6^{* * *}$ \\
\hline $\mathrm{Ba}(\mathrm{mg} / \mathrm{L})$ & $0.03^{a}$ & $(0.0)$ & $0.05^{\mathrm{a}}$ & $(0.0)$ & $0.02^{\mathrm{a}}$ & $(0.0)$ & $2.35^{\mathrm{NS}}$ \\
\hline $\mathrm{Ca}(\mathrm{mg} / \mathrm{L})$ & $11.97^{\mathrm{a}}$ & (1.7) & $2.29^{a}$ & $(0.3)$ & $86.60^{b}$ & $(12.6)$ & $35.5^{* * *}$ \\
\hline $\mathrm{Cl}(\mathrm{mg} / \mathrm{L})$ & $2.27^{\mathrm{a}}$ & $(0.2)$ & $1.01^{\mathrm{a}}$ & $(0.1)$ & $6.83^{b}$ & $(1.6)$ & $9.9^{* * *}$ \\
\hline Co (mg/L) & $0.02^{\mathrm{a}}$ & $(0.0)$ & $0.02^{\mathrm{a}}$ & $(0.0)$ & $0.10^{b}$ & $(0.0)$ & $17.9^{* * *}$ \\
\hline $\mathrm{Cu}(\mathrm{mg} / \mathrm{L})$ & $0.02^{\mathrm{a}}$ & $(0.0)$ & $0.02^{\mathrm{a}}$ & $(0.0)$ & $0.03^{b}$ & $(0.0)$ & $4.2^{*}$ \\
\hline $\mathrm{Fe}(\mathrm{mg} / \mathrm{L})$ & $0.19^{a}$ & $(0.0)$ & $0.21^{a}$ & $(0.1)$ & $17.17^{b}$ & (6.4) & $6.2^{* *}$ \\
\hline $\mathrm{Mg}(\mathrm{mg} / \mathrm{L})$ & $1.68^{a}$ & $(0.2)$ & $0.94^{\mathrm{a}}$ & $(0.1)$ & $34.10^{b}$ & (5.4) & $32.7^{* * *}$ \\
\hline $\mathrm{Mn}(\mathrm{mg} / \mathrm{L})$ & $0.11^{a}$ & $(0.0)$ & $0.13^{\mathrm{a}}$ & $(0.0)$ & $3.90^{\mathrm{b}}$ & $(0.7)$ & $29.5^{\star * *}$ \\
\hline $\mathrm{Na}(\mathrm{mg} / \mathrm{L})$ & $1.55^{\mathrm{a}}$ & $(0.2)$ & $0.95^{\mathrm{a}}$ & $(0.4)$ & $6.90^{b}$ & (1.2) & $18.5^{* * *}$ \\
\hline $\mathrm{Ni}(\mathrm{mg} / \mathrm{L})$ & $0.05^{a}$ & $(0.0)$ & $0.07^{a}$ & $(0.0)$ & $0.18^{b}$ & $(0.0)$ & $15.5^{\star * *}$ \\
\hline $\mathrm{Se}(\mathrm{mg} / \mathrm{L})$ & $0.10^{a}$ & $(0.0)$ & $0.09^{a}$ & $(0.0)$ & $0.05^{\mathrm{a}}$ & $(0.0)$ & $2.2^{\mathrm{NS}}$ \\
\hline Zn (mg/L) & $0.02^{\mathrm{a}}$ & $(0.0)$ & $0.03^{a}$ & $(0.0)$ & $0.32^{b}$ & $(0.1)$ & $25.4^{\star * *}$ \\
\hline $\mathrm{SO}^{4}(\mathrm{mg} / \mathrm{L})$ & $12.85^{\mathrm{a}}$ & $(0.8)$ & $11.21^{\mathrm{a}}$ & $(0.2)$ & $529.70^{b}$ & (61.2) & $64.1^{* * *}$ \\
\hline TSS (mg/L) & $5.83^{\mathrm{a}}$ & $(1.9)$ & $5.06^{a}$ & $(1.3)$ & $7.18^{a}$ & $(2.2)$ & $0.3^{\mathrm{NS}}$ \\
\hline $\mathrm{PC} 1$ & $-2.25^{a}$ & $(0.31)$ & $-1.58^{a}$ & $(0.27)$ & $4.06^{b}$ & $(0.44)$ & $99.41^{* * *}$ \\
\hline $\mathrm{PC} 2$ & $0.26^{a}$ & $(0.07)$ & $-1.76^{b}$ & $(0.39)$ & $0.24^{\mathrm{a}}$ & $(0.23)$ & $19.26^{* * *}$ \\
\hline
\end{tabular}

Note: Parameters with the same lowercase superscript letter did not significantly differ among stream type $(p<0.1)$ ${ }^{*} p<0.1 \quad{ }^{* *} p<0.01 \quad{ }^{* * *} p<0.001 \quad$ NS, not significant.

† SpC, specific conductivity; TSS, total suspended solid; PC, principle component 
Table 7: Mean $( \pm S E)$ water chemistry parameters by site type for the spring decomposition trial. F-values come from ANOVAs of each water chemistry parameter (d.f.=2).

\begin{tabular}{|c|c|c|c|c|c|c|c|}
\hline \multirow{3}{*}{$\begin{array}{l}\text { Chemistry parameter } \dagger \\
\text { Discharge }\left(\mathrm{m}^{3}\right)\end{array}$} & \multicolumn{6}{|c|}{ Stream type } & \multirow{3}{*}{$\frac{F \text {-value }}{1.07^{\text {Ns }}}$} \\
\hline & \multicolumn{2}{|c|}{$\frac{\text { Circumneutral }}{(n=5)}$} & \multicolumn{2}{|c|}{$\frac{\text { Acid precipitation }}{(\mathrm{n}=5)}$} & \multicolumn{2}{|c|}{$\frac{\text { Acid mine drainage }}{(\mathrm{n}=5)}$} & \\
\hline & $0.5^{a}$ & $(0.2)$ & $0.3^{\mathrm{a}}$ & $(0.1)$ & $0.4^{a}$ & $(0.1)$ & \\
\hline Temperature $\left({ }^{\circ} \mathrm{C}\right)$ & $11.0^{\mathrm{a}}$ & $(0.4)$ & $9.7^{b}$ & $(0.1)$ & $11.2^{\mathrm{a}}$ & $(0.2)$ & $10.34^{* *}$ \\
\hline $\mathrm{pH}$ & $6.8^{a}$ & $(0.1)$ & $5.4^{\mathrm{b}}$ & $(0.10)$ & $4.4^{\mathrm{c}}$ & $(0.1)$ & $131.43^{* * *}$ \\
\hline $\mathrm{SpC}(\mu \mathrm{S} / \mathrm{cm})$ & $87.7^{\mathrm{a}}$ & $(5.9)$ & $55.1^{a}$ & $(2.6)$ & $1632.2^{b}$ & $(128.7)$ & $146.89^{* * *}$ \\
\hline Alkalinity (mg/L) & $17.1^{a}$ & $(2.7)$ & $1.3^{\mathrm{a}, \mathrm{b}}$ & $(0.2)$ & $0.7^{b}$ & $(0.0)$ & $35.99^{* * *}$ \\
\hline Acidity (mg/L) & $108.8^{a}$ & $(5.6)$ & $126.7^{\mathrm{a}}$ & (3.1) & $241.5^{\mathrm{b}}$ & $(52.0)$ & $5.66^{*}$ \\
\hline $\mathrm{Al}(\mathrm{mg} / \mathrm{L})$ & $0.1^{a}$ & $(0.0)$ & $0.3^{\mathrm{a}}$ & $(0.1)$ & $9.5^{\mathrm{b}}$ & $(1.7)$ & $29.12^{* * *}$ \\
\hline $\mathrm{Ba}(\mathrm{mg} / \mathrm{L})$ & $0.1^{a, b}$ & $(0.0)$ & $0.1^{\mathrm{a}}$ & $(0.0)$ & $0.0^{b}$ & $(0.0)$ & $3.95^{*}$ \\
\hline $\mathrm{Ca}(\mathrm{mg} / \mathrm{L})$ & $8.9^{a}$ & $(1.6)$ & $2.1^{\mathrm{a}}$ & (0.3) & $65.5^{b}$ & $(14.2)$ & $17.80^{* * *}$ \\
\hline $\mathrm{Cl}(\mathrm{mg} / \mathrm{L})$ & $2.2^{\mathrm{a}}$ & $(0.3)$ & $1.2^{\mathrm{a}}$ & (0.1) & $6.7^{\mathrm{a}}$ & $(2.7)^{\prime}$ & $3.32^{\mathrm{NS}}$ \\
\hline Co (mg/L) & $0.0^{\mathrm{a}}$ & $(0.0)$ & $0.1^{\mathrm{a}}$ & $(0.0)$ & $0.1^{\mathrm{a}}$ & $(0.0)$ & $2.74^{\mathrm{NS}}$ \\
\hline $\mathrm{Cu}(\mathrm{mg} / \mathrm{L})$ & $0.0^{a}$ & $(0.0)$ & $0.1^{\mathrm{a}}$ & $(0.0)$ & $0.0^{a}$ & $(0.0)$ & $1.01^{\mathrm{NS}}$ \\
\hline $\mathrm{Fe}(\mathrm{mg} / \mathrm{L})$ & $0.5^{\mathrm{a}}$ & $(0.0)$ & $0.5^{\mathrm{a}}$ & $(0.1)$ & $20.3^{b}$ & $(4.7)$ & $17.46^{* * *}$ \\
\hline $\mathrm{Mg}(\mathrm{mg} / \mathrm{L})$ & $0.8^{a}$ & $(0.1)$ & $0.7^{\mathrm{a}}$ & $(0.1)$ & $19.2^{b}$ & $(4.4)$ & $18.01^{* * *}$ \\
\hline $\mathrm{Mn}(\mathrm{mg} / \mathrm{L})$ & $0.1^{a}$ & $(0.0)$ & $0.2^{\mathrm{a}}$ & $(0.0)$ & $3.7^{\mathrm{b}}$ & (1.2) & $8.56^{\star *}$ \\
\hline $\mathrm{Na}(\mathrm{mg} / \mathrm{L})$ & $1.3^{a}$ & $(0.2)$ & $1.3^{\mathrm{a}}$ & $(0.5)$ & $6.8^{b}$ & $(1.9)$ & $7.76^{* *}$ \\
\hline $\mathrm{Ni}(\mathrm{mg} / \mathrm{L})$ & $0.0^{\mathrm{a}}$ & $(0.0)$ & $0.1^{\mathrm{a}}$ & $(0.0)$ & $0.2^{\mathrm{b}}$ & $(0.0)$ & $12.59^{* *}$ \\
\hline $\mathrm{Se}(\mathrm{mg} / \mathrm{L})$ & $0.1^{a}$ & $(0.0)$ & $0.1^{\mathrm{a}}$ & $(0.0)$ & $0.1^{\mathrm{a}}$ & $(0.0)$ & $1.68^{\mathrm{NS}}$ \\
\hline $\mathrm{Zn}(\mathrm{mg} / \mathrm{L})$ & $0.0^{a}$ & $(0.0)$ & $0.1^{a}$ & $(0.0)$ & $0.3^{b}$ & $(0.1)$ & $22.16^{* * *}$ \\
\hline SO4 (mg/L) & $12.7^{\mathrm{a}}$ & $(1.0)$ & $10.9^{a}$ & $(0.2)$ & $477.6^{\mathrm{b}}$ & (78.5) & $35.19^{\star \star *}$ \\
\hline TSS (mg/L) & $8.8^{a}$ & $(2.2)$ & $7.6^{\mathrm{a}}$ & $(4.0)$ & $9.9^{a}$ & $(4.4)$ & $0.09^{\mathrm{Ns}}$ \\
\hline PC1 & $-2.24^{a}$ & $(0.08)$ & $-2.11^{a}$ & $(0.11)$ & $4.23^{b}$ & $(0.40)$ & $233.96^{* * *}$ \\
\hline $\mathrm{PC} 2$ & $0.52^{a}$ & $(0.06)$ & $-1.74^{b}$ & $(0.38)$ & $0.03^{a}$ & $(0.27)$ & $19.32^{* * *}$ \\
\hline
\end{tabular}

Note: Parameters with the same lowercase superscript letter did not significantly differ among stream type $(p<0.1)$

${ }^{*} p<0.1 \quad{ }^{* *} p<0.01 \quad$ *** $p<0.001 \quad$ NS, not significant.

† SpC, specific conductivity; TSS, total suspended solids; PC, principal component 
Table 8: Annual average water chemistry parameters by stream type across three seasonal sampling periods, together with $\mathrm{F}$ values from repeated measures ANOVA designed to detect an effect of stream type and season on each water chemistry variable.

\begin{tabular}{|c|c|c|c|c|c|c|c|c|c|}
\hline \multirow[b]{2}{*}{ Chemical parameter $\dagger$} & \multicolumn{6}{|c|}{ Stream type } & \multirow[b]{2}{*}{$\begin{array}{c}\text { Type } \\
F_{2} \\
\end{array}$} & \multirow[b]{2}{*}{$\begin{array}{c}\text { Season } \\
F_{2}\end{array}$} & \multirow{2}{*}{$\begin{array}{c}\text { Type } X \\
\text { season } \\
F_{4}\end{array}$} \\
\hline & $\underline{\text { Circl }}$ & imneutral & Acid $p$ & ecipitation & Acid $m$ & ne drainage & & & \\
\hline Discharge $\left(\mathrm{m}^{3} / \mathrm{s}\right)$ & $0.31^{a}$ & $(0.08)$ & $0.17^{a}$ & $(0.04)$ & $0.26^{a}$ & $(0.07)$ & $1.6^{\mathrm{NS}}$ & $9.93^{* * *}$ & $0.48^{N S}$ \\
\hline Temperature $\left({ }^{\circ} \mathrm{C}\right)$ & $10.71^{\mathrm{a}}$ & $(0.74)$ & $10.17^{a}$ & $(0.75)$ & $11.53^{b}$ & $(0.89)$ & $13.73^{* * *}$ & $366.01^{* * *}$ & $3.06^{*}$ \\
\hline $\mathrm{pH}$ & $6.81^{\mathrm{a}}$ & $(0.12)$ & $5.42^{\mathrm{b}}$ & $(0.10)$ & $3.96^{\mathrm{c}}$ & $(0.13)$ & $266.82^{* * *}$ & $2.65^{*}$ & $7.325^{* * *}$ \\
\hline $\mathrm{SpC}(\mu \mathrm{S} / \mathrm{cm})$ & $87.64^{\mathrm{a}}$ & (5.65) & $38.07^{a}$ & $(3.40)$ & $1298.72^{b}$ & $(108.04)$ & $182.18^{\star * *}$ & $4.19^{*}$ & $3.56^{*}$ \\
\hline Alkalinity (mg/L) & $24.87^{\mathrm{a}}$ & (3.09) & $1.80^{\mathrm{b}}$ & $(0.26)$ & $0.23^{b}$ & $(0.08)$ & $79.16^{\star \star \star}$ & $3.36^{*}$ & $3.36^{*}$ \\
\hline Acidity (mg/L) & $63.18^{a}$ & $(11.50)$ & $75.66^{a}$ & $(12.50)$ & $245.90^{b}$ & $(36.83)$ & $19.4^{* * *}$ & $2.01^{\mathrm{Ns}}$ & $0.71^{\mathrm{Ns}}$ \\
\hline $\mathrm{Al}(\mathrm{mg} / \mathrm{L})$ & $0.11^{\mathrm{a}}$ & $(0.02)$ & $0.28^{a}$ & $(0.04)$ & $13.76^{b}$ & $(1.86)$ & $68.03^{* * *}$ & $2.68^{*}$ & $2.95^{*}$ \\
\hline $\mathrm{Ba}(\mathrm{mg} / \mathrm{L})$ & $0.04^{a, b}$ & $(0.01)$ & $0.06^{a}$ & $(0.01)$ & $0.02^{b}$ & $(0.00)$ & $7.37^{* *}$ & $4.04^{*}$ & $1.66^{\mathrm{NS}}$ \\
\hline $\mathrm{Ca}(\mathrm{mg} / \mathrm{L})$ & $12.56^{\mathrm{a}}$ & (1.63) & $2.19^{a}$ & $(0.18)$ & $88.35^{b}$ & (10.04) & $75.12^{* * *}$ & $2.83^{\mathrm{NS}}$ & $1.87^{\mathrm{NS}}$ \\
\hline $\mathrm{Cl}(\mathrm{mg} / \mathrm{L})$ & $2.24^{a}$ & $(0.20)$ & $1.08^{a}$ & (0.05) & $6.27^{b}$ & $(1.38)$ & $9.93^{* * *}$ & $0.1^{\mathrm{NS}}$ & $0.1^{\mathrm{NS}}$ \\
\hline Co (mg/L) & $0.02^{\mathrm{a}}$ & (0.01) & $0.03^{a}$ & (0.01) & $0.11^{b}$ & (0.01) & $41.26^{\star * *}$ & $1.02^{\mathrm{NS}}$ & $2.81^{*}$ \\
\hline $\mathrm{Cu}(\mathrm{mg} / \mathrm{L})$ & $0.02^{\mathrm{a}}$ & (0.01) & $0.03^{a}$ & (0.01) & $0.02^{\mathrm{a}}$ & $(0.00)$ & $0.52^{\mathrm{NS}}$ & $2.79^{*}$ & $1.34^{\mathrm{NS}}$ \\
\hline $\mathrm{Fe}(\mathrm{mg} / \mathrm{L})$ & $0.30^{\mathrm{a}}$ & (0.05) & $0.32^{a}$ & $(0.06)$ & $21.62^{b}$ & (6.76) & $8.76^{\star \star *}$ & $0.17^{\mathrm{NS}}$ & $0.17^{\mathrm{NS}}$ \\
\hline $\mathrm{Mg}(\mathrm{mg} / \mathrm{L})$ & $1.45^{\mathrm{a}}$ & $(0.15)$ & $0.81^{a}$ & (0.05) & $33.32^{b}$ & (4.77) & $64.69^{* * *}$ & $4.28^{*}$ & $3.75^{*}$ \\
\hline $\mathrm{Mn}(\mathrm{mg} / \mathrm{L})$ & $0.09^{a}$ & (0.01) & $0.15^{a}$ & $(0.02)$ & $4.52^{b}$ & (0.71) & $38.47^{* * *}$ & $1.04^{\mathrm{NS}}$ & $1.04^{\mathrm{NS}}$ \\
\hline $\mathrm{Na}(\mathrm{mg} / \mathrm{L})$ & $3.01^{a}$ & $(0.79)$ & $2.51^{\mathrm{a}}$ & (0.68) & $8.47^{b}$ & (1.53) & $11.69^{* * *}$ & $7.4^{* *}$ & $0.02^{\mathrm{NS}}$ \\
\hline $\mathrm{Ni}(\mathrm{mg} / \mathrm{L})$ & $0.04^{a}$ & (0.01) & $0.05^{a}$ & (0.01) & $0.19^{b}$ & (0.01) & $65.95^{\star * *}$ & $1.44^{\mathrm{NS}}$ & $0.68^{N S}$ \\
\hline $\mathrm{Se}(\mathrm{mg} / \mathrm{L})$ & $0.10^{\mathrm{a}}$ & (0.01) & $0.09^{a}$ & $(0.02)$ & $0.06^{a}$ & $(0.00)$ & $3.66^{*}$ & $8.28^{\star *}$ & $1.059^{\mathrm{NS}}$ \\
\hline $\mathrm{Zn}(\mathrm{mg} / \mathrm{L})$ & $0.02^{a}$ & $(0.00)$ & $0.04^{a}$ & $(0.01)$ & $0.36^{b}$ & $(0.03)$ & $89.67^{* * *}$ & $0.77^{\mathrm{NS}}$ & $0.97^{\mathrm{NS}}$ \\
\hline $\mathrm{SO}_{4}(\mathrm{mg} / \mathrm{L})$ & $12.21^{a}$ & $(0.56)$ & $10.69^{a}$ & $(0.16)$ & $585.33^{b}$ & (66.28) & $82.83^{* * *}$ & $1.69^{\mathrm{NS}}$ & $1.75^{\mathrm{NS}}$ \\
\hline TSS (mg/L) & $11.67^{\mathrm{a}}$ & (1.97) & $13.15^{a}$ & (5.37) & $16.50^{a}$ & $(6.22)$ & $0.29^{\mathrm{NS}}$ & $5.89^{\mathrm{NS}}$ & $0.17^{\mathrm{NS}}$ \\
\hline PC1 & -2.43 & $(0.12)$ & -2.05 & $(0.14)$ & 4.49 & $(0.29)$ & $455.47^{\star \star \star}$ & $0.03^{N S}$ & $2.75^{\star *}$ \\
\hline $\mathrm{PC} 2$ & 1.05 & $(0.27)$ & -1.19 & $(0.28)$ & 0.14 & $(0.13)$ & $2.9^{\star}$ & $8.65^{\star * *}$ & $1.42^{\mathrm{NS}}$ \\
\hline
\end{tabular}

Note: Parameters with the same lowercase superscript letter did not significantly differ among stream type $(p<0.1)$

${ }^{*} p<0.1 \quad{ }^{* *} p<0.01 \quad{ }^{* * *} p<0.001 \quad$ NS, not significant

† SpC, specific conductivity; TSS, total suspended solids; PC, principal component. 
Table 9: Relationship of water chemistry variables and macroinvertebrate metrics to nonmetric multidimensional scaling (NMDS) ordination of macroinvertebrate genera in 2 dimensions by vector fitting. Corresponding $r^{2}$ and $p$-values are given. P-values are estimated from 1000 randomizations of data.

\begin{tabular}{|c|c|c|}
\hline Variable & Vector $r^{2}$ & $p$-value \\
\hline \multicolumn{3}{|c|}{ Water chemistry $\dagger$} \\
\hline $\mathrm{pH}$ & 0.91 & $<0.001$ \\
\hline $\mathrm{SpC}$ & 0.89 & $<0.001$ \\
\hline Alkalinity & 0.52 & 0.027 \\
\hline Acidity & 0.68 & $<0.001$ \\
\hline Al & 0.85 & $<0.001$ \\
\hline $\mathrm{Ba}$ & 0.21 & 0.249 \\
\hline $\mathrm{Ca}$ & 0.91 & $<0.001$ \\
\hline $\mathrm{Cl}$ & 0.38 & 0.062 \\
\hline Co & 0.81 & 0.002 \\
\hline $\mathrm{Cr}$ & 0.05 & 0.77 \\
\hline $\mathrm{Cu}$ & 0.02 & 0.869 \\
\hline $\mathrm{Fe}$ & 0.54 & 0.011 \\
\hline $\mathrm{Mg}$ & 0.84 & $<0.001$ \\
\hline $\mathrm{Mn}$ & 0.63 & $<0.001$ \\
\hline $\mathrm{Na}$ & 0.56 & 0.012 \\
\hline $\mathrm{Ni}$ & 0.85 & $<0.001$ \\
\hline $\mathrm{Se}$ & 0.2 & 0.251 \\
\hline $\mathrm{Zn}$ & 0.89 & $<0.001$ \\
\hline $\mathrm{SO}_{4}$ & 0.91 & $<0.001$ \\
\hline TSS & 0.36 & 0.067 \\
\hline \multicolumn{3}{|c|}{ Invertebrate metric †† } \\
\hline WVSCI & 0.91 & $<0.001$ \\
\hline Num & 0.63 & 0.002 \\
\hline$\%$ EPT & 0.81 & $<0.001$ \\
\hline EPT & 0.90 & $<0.001$ \\
\hline$\%$ Tol & 0.81 & $<0.001$ \\
\hline$\% \mathrm{E}$ & 0.59 & 0.007 \\
\hline MHI & 0.74 & $<0.001$ \\
\hline \% Dom & 0.85 & $<0.001$ \\
\hline FRich & 0.95 & $<0.001$ \\
\hline$\%$ Aci.Tol & 0.31 & 0.11 \\
\hline$\%$ Al.Tol & 0.55 & 0.012 \\
\hline
\end{tabular}

† SpC, specific conductivity; TSS, total suspended solids.

t† WVSCl, West Virginia stream condition index; Num, number of individual macroinvertebrates; \% EPT, percent Ephemeroptera, Plecoptera and Trichoptera; EPT, Genus richness of Ephemeroptera, Plecoptera and Trichoptera; \% Tol, percent tolerant; \% E, percent Ephemeroptera; MHI, Modified hilsenhoff index; \% Dom, percent dominant; FRich, family richness; \% Aci.Tol, percent acid tolerant; \% Al.Tol, percent Al tolerant 
Table 10: Mean ( \pm SE) invertebrate metrics for each stream type. F-values come from ANOVAs of each variable (d.f. $=2$ ).

\begin{tabular}{|c|c|c|c|c|c|c|c|}
\hline \multirow{3}{*}{$\frac{\text { Metrics † }}{\text { WVSCI }}$} & \multicolumn{6}{|c|}{ Stream type } & \multirow{3}{*}{$\frac{\text { F-value }}{106.48^{* * *}}$} \\
\hline & \multicolumn{2}{|c|}{$\frac{\text { Circumneutral }}{(n=5)}$} & \multicolumn{2}{|c|}{$\frac{\text { Acid precipitation }}{(\mathrm{n}=5)}$} & \multicolumn{2}{|c|}{$\frac{\text { Acid mine drainage }}{(n=5)}$} & \\
\hline & $90.3^{a}$ & $(3.6)$ & $71.4^{b}$ & $(3.9)$ & $23.5^{\mathrm{c}}$ & $(2.1)$ & \\
\hline Num & $3078.5^{a}$ & (418.1) & $2560.6^{a}$ & $(650.8)$ & $220.1^{\mathrm{b}}$ & (64.7) & $11.54^{* *}$ \\
\hline$\%$ EPT & $64.8^{a}$ & $(6.8)$ & $53.9^{a}$ & $(7.1)$ & $5.2^{\mathrm{b}}$ & $(1.7)$ & $30.36^{* * *}$ \\
\hline EPT & $29.8^{a}$ & (1.15) & $18.6^{b}$ & $(2.54)$ & $6.4^{\mathrm{c}}$ & (2.08) & $33.79^{* * *}$ \\
\hline$\%$ Tol & $13.1^{\mathrm{a}}$ & $(2.1)$ & $36.7^{b}$ & $(7.5)$ & $85.8^{c}$ & $(2.7)$ & $60.60^{* * *}$ \\
\hline$\% \mathrm{E}$ & $44.1^{a}$ & (5.9) & $1.3^{b}$ & $(0.4)$ & $0.2^{b}$ & $(0.2)$ & $54.19^{* * *}$ \\
\hline $\mathrm{MHI}$ & $4.0^{a}$ & $(0.2)$ & $4.5^{\mathrm{a}}$ & $(0.3)$ & $7.2^{\mathrm{b}}$ & $(0.3)$ & $38.27^{* * *}$ \\
\hline$\%$ Dom & $25.1^{\mathrm{a}}$ & $(2.8)$ & $45.1^{\mathrm{b}}$ & $(1.2)$ & $81.0^{c}$ & (2.9) & $136.58^{* * *}$ \\
\hline FRich & $29.2^{a}$ & $(1.2)$ & $20.6^{b}$ & $(1.0)$ & $4.9^{c}$ & $(1.1)$ & $122.77^{* * *}$ \\
\hline
\end{tabular}

Note: Parameters with the same lowercase superscript letter did not significantly differ among stream type $(p<0.1)$

${ }^{*} p<0.1 \quad{ }^{* *} p<0.01 \quad{ }^{* * *} p<0.001 \quad$ NS, not significant

†WVSCI, West Virginia stream condition index; Num, number of individual macroinvertebrates;

\% EPT, percent Ephemeroptera, Plecoptera and Trichoptera; EPT, Genus richness of Ephemeroptera, Plecoptera and Trichoptera; \% Tol, percent tolerant; \% E, percent Ephemeroptera; MHI, Modified hilsenhoff index; \% Dom, percent dominant; FRich, family richness. 
Table 11: Results from an analysis of similarity (ANOSIM) including all pairwise comparisons of shredder assemblage among the stream types. $\mathrm{CN}=$ circumneutral, $\mathrm{AP}=$ acid precipitation, and $A M D=$ acid mine drainage. p-values are estimated from 1000 randomizations of the data.

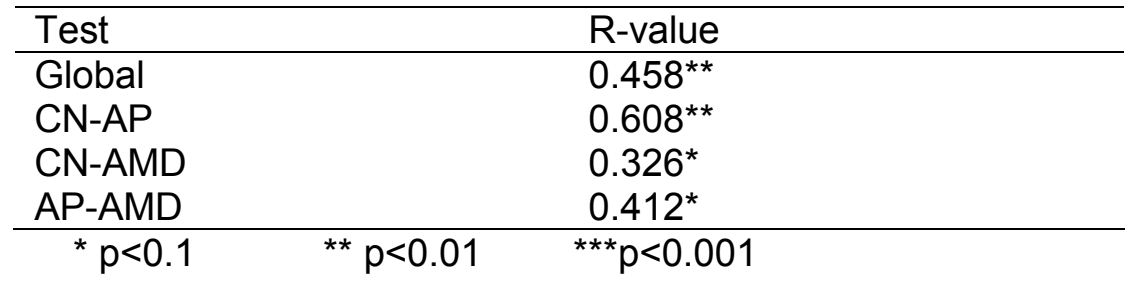


Table 12: Mean $( \pm S E)$ number of total shredders and number of shredders from different taxa for each stream type. F-values come from ANOVAs of each variable (d.f.=2).

\begin{tabular}{|c|c|c|c|c|c|c|c|}
\hline \multirow[b]{3}{*}{ \# Shredders } & \multicolumn{6}{|c|}{ Stream type } & \multirow{3}{*}{$\frac{F \text {-value }}{15.45^{\text {*** }}}$} \\
\hline & \multicolumn{2}{|c|}{$\frac{\text { Circumneutral }}{(n=5)}$} & \multicolumn{2}{|c|}{$\frac{\text { Acid precipitation }}{(\mathrm{n}=5)}$} & \multicolumn{2}{|c|}{$\frac{\text { Acid mine drainage }}{(n=5)}$} & \\
\hline & $288.5^{a}$ & (92.2) & $1131.9^{b}$ & $(240.8)$ & $7.5^{\mathrm{a}}$ & $(2.6)$ & \\
\hline Shredder richness & $12.2^{\mathrm{a}}$ & $(0.9)$ & $12.2^{\mathrm{a}}$ & $(1.2)$ & $2.4^{\mathrm{b}}$ & $(0.5)$ & $37.81^{* * *}$ \\
\hline \# Voracious shredders & $123.6^{\mathrm{a}}$ & (93.7) & $23.7^{a}$ & (9.3) & $0^{a}$ & (0) & $1.45^{\mathrm{NS}}$ \\
\hline \# Shredding Trichoptera & $18.0^{\mathrm{a}}$ & $(6.4)$ & $17.3^{a}$ & $(6.8)$ & $0.1^{a}$ & $(0.1)$ & $3.56^{\mathrm{NS}}$ \\
\hline \# Shredding Plecoptera & $147.9^{a}$ & (30.3) & $1051.8^{a}$ & $(234.9)$ & $6.3^{b}$ & (2.3) & $17.19^{* \star \star}$ \\
\hline \# Tipulidae & $4.9^{a}$ & $(2.0)$ & $3.8^{\mathrm{a}}$ & $(1.4)$ & $0.2^{\mathrm{a}}$ & $(0.1)$ & $2.96^{\mathrm{NS}}$ \\
\hline \#Nemouridae & $47.6^{\mathrm{a}}$ & (30.3) & $517.9^{b}$ & (198.9) & $1.9^{a}$ & $(1.8)$ & $6.05^{*}$ \\
\hline
\end{tabular}

Note: Parameters with the same lowercase superscript letter did not significantly differ among stream type $(p<0.1)$

${ }^{*} p<0.1 \quad{ }^{* *} p<0.01 \quad{ }^{* * *} p<0.001 \quad$ NS, not significant 
Table 13: Mean ( \pm SE) measures of microbial activity by site type. F-values come from ANOVAsof each variable (d.f. $=2$ ).

\begin{tabular}{|c|c|c|c|c|}
\hline & \multicolumn{3}{|c|}{ Stream type } & \multirow[b]{2}{*}{ F-value } \\
\hline & $\frac{\text { Circumneutral }}{(n=5)}$ & $\frac{\text { Acid precipitation }}{(n=5)}$ & $\frac{\text { Acid mine drainage }}{(n=5)}$ & \\
\hline $\begin{array}{l}\text { Respiration } \\
\left(\mathrm{mg} \mathrm{O} \mathrm{O}^{2} \mathrm{~L}^{*} \mathrm{~d}\right) \\
\text { Ergosterol } \\
(\mu \mathrm{g} / \mathrm{ml})\end{array}$ & $\begin{array}{rr}1.47^{\mathrm{a}} & (0.30) \\
14.38^{\mathrm{a}} & (1.57)\end{array}$ & $\begin{array}{c}1.07^{b} \\
12.91^{a, b}\end{array}$ & $\begin{array}{r}1.17^{\mathrm{b}} \\
12.26^{\mathrm{a}} \\
\end{array}$ & $7.08^{* *}$ \\
\hline
\end{tabular}

Note: Parameters with the same lowercase superscript letter did not significantly differ among stream type $(p<0.1)$

${ }^{*} p<0.1 \quad{ }^{* *} p<0.01 \quad{ }^{* * *} p<0.001 \quad$ NS, not significant 
Table 14: F-values from repeated measures ANOVA of the remaining leaf mass from each seasonal decomposition trial.

\begin{tabular}{llll}
\hline & Stream type & Days of exposure & Day X type interaction \\
\hline Summer & $13.77^{* * *}$ & $194.06^{* * *}$ & $9.41^{* * *}$ \\
Winter & $4.97^{*}$ & $181.7^{* * *}$ & 1.94 \\
Spring & $11.71^{* * *}$ & $168.96^{* * *}$ & $5.25^{* *}$ \\
\hline${ }^{*} p<0.1$ & ${ }^{* *} p<0.01$ & ${ }^{* * *} p<0.001$ &
\end{tabular}


Table 15: Seasonal and annual mean $( \pm S E)$ decomposition rates for each stream.

\begin{tabular}{lccccc}
\hline & \multicolumn{3}{c}{ Decomposition Rate $\left(\mathrm{g}^{-\mathrm{d}}\right)$} \\
type & Summer 2009 & Winter 2010 & Spring 2010 & \multicolumn{2}{c}{ Annual Average } \\
\hline CN 1 & 0.008 & 0.019 & 0.007 & 0.011 & $(0.003)$ \\
CN 2 & 0.011 & 0.015 & 0.006 & 0.011 & $(0.002)$ \\
CN 3 & 0.025 & 0.02 & 0.008 & 0.018 & $(0.004)$ \\
CN 4 & 0.008 & 0.006 & 0.008 & 0.007 & $(0.000)$ \\
CN 5 & 0.011 & 0.031 & 0.034 & 0.025 & $(0.005)$ \\
AP 1 & 0.009 & 0.004 & 0.004 & 0.006 & $(0.001)$ \\
AP 2 & 0.007 & 0.013 & 0.007 & 0.009 & $(0.001)$ \\
AP 3 & 0.007 & 0.003 & 0.006 & 0.005 & $(0.001)$ \\
AP 4 & 0.005 & 0.012 & 0.007 & 0.008 & $(0.001)$ \\
AP 5 & 0.008 & 0.003 & 0.004 & 0.005 & $(0.001)$ \\
AMD 1 & 0.002 & 0.003 & 0.001 & 0.002 & $(0.000)$ \\
AMD 2 & 0.006 & 0.006 & 0.004 & 0.005 & $(0.000)$ \\
AMD 3 & 0.006 & 0.004 & 0.004 & 0.005 & $(0.000)$ \\
AMD 4 & 0.004 & 0.01 & 0.008 & 0.007 & $(0.001)$ \\
AMD 5 & 0.004 & 0.004 & 0.003 & 0.004 & $(0.000)$ \\
\hline
\end{tabular}


Table 16: Mean ( \pm SE) decomposition rates for each stream type. F-values are from ANOVAs between stream types (d.f. $=2$ )

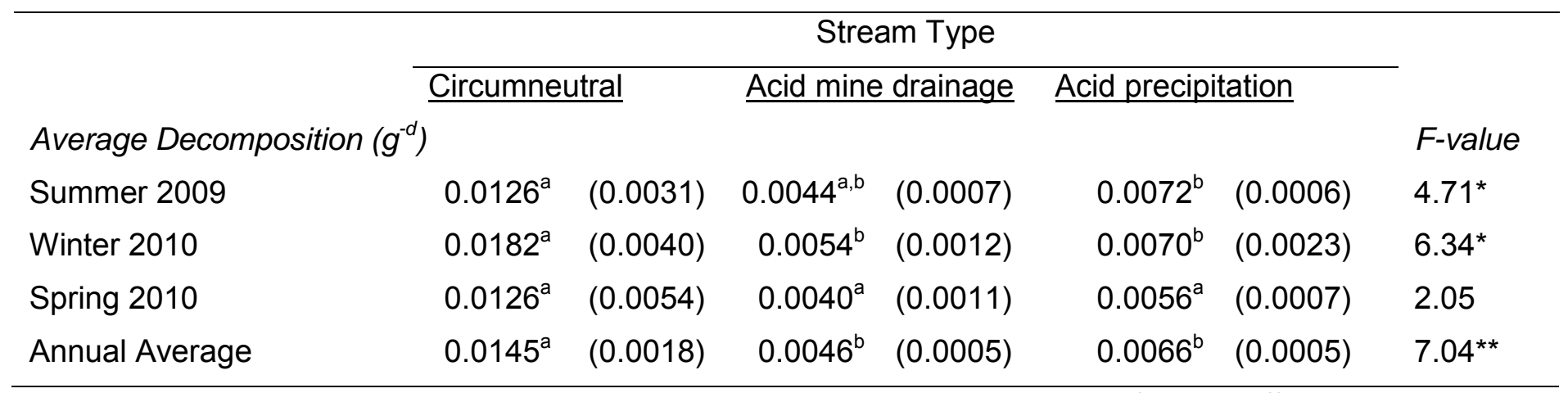

Note: Parameters with the same lowercase superscript letter did not significantly differ among stream type $(p<0.1)$

${ }^{*} p<0.1$

${ }^{* *} p<0.01$

${ }^{* * *} p<0.001 \quad N S$, not significant 
Table 17: Results of a two way ANOVA between site type and season to determine if season had an influence on decomposition rate.

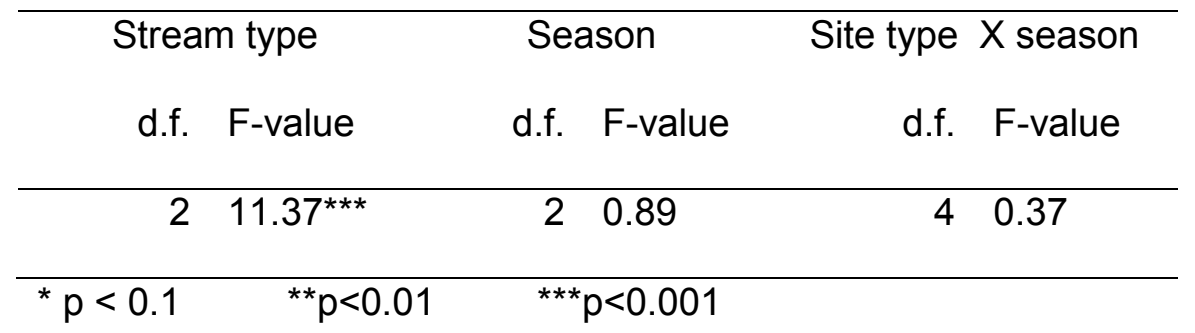


Table 18: Results of ANCOVAs to determine if physical stream parameters influenced decomposition rates.

\begin{tabular}{lrlrlrl}
\hline & \multicolumn{2}{c}{ Site type } & Physical parameter & \multicolumn{2}{c}{ Site type X parameter } \\
\hline & d.f. & F-value & d.f. & F-value & d.f. & F-value \\
Drainage area $\left(\mathrm{km}^{2}\right)$ & 2 & $13.55^{* *}$ & 1 & $5.12^{*}$ & 2 & $4.49^{*}$ \\
Discharge $\left(\mathrm{m}^{3} / \mathrm{s}\right)$ & 2 & $19.98^{* * *}$ & 1 & $15.67^{* *}$ & 2 & $4.69^{*}$ \\
Slope $(\%)$ & 2 & $5.37^{*}$ & 1 & 0.14 & 2 & 0.01 \\
Temperature ${ }^{\circ} \mathrm{C}$ & 2 & $12.94^{* *}$ & 1 & $10.25^{*}$ & 2 & 1.41 \\
\hline \multicolumn{2}{c}{${ }^{*} \mathrm{p}<0.1$} & & ${ }^{* *} \mathrm{p}<0.01$ & ${ }^{* * *} \mathrm{p}<0.001$ & &
\end{tabular}


Table 19: Results of ANCOVAs to determine if total number of shredders or number of shredders from different taxa influenced decomposition rates.

\begin{tabular}{lrlrrrr}
\hline & \multicolumn{2}{c}{ Site type } & Shredder variable & \multicolumn{2}{c}{$\begin{array}{c}\text { Site type X shredder } \\
\text { variable }\end{array}$} \\
& d.f. & F-value & d.f. & F-value & d.f. & F-value \\
\hline \# Shredders & 2 & $6.89^{*}$ & 1 & 0.07 & 2 & 1.34 \\
Shredder richness & 2 & $6.45^{*}$ & 1 & 1.52 & 2 & 0.24 \\
\# Voracious shredders & 2 & 6.45 & 1 & 0.74 & 2 & 0.26 \\
\# Shredding Trichoptera & 2 & $9.68^{* *}$ & 1 & $4.41^{*}$ & 2 & 1.55 \\
\# Shredding Plecoptera & 2 & $7.57^{*}$ & 1 & 0.01 & 2 & 1.95 \\
\# Tipulidae & 2 & $5.66^{*}$ & 1 & 0.01 & 2 & 0.32 \\
\# Nemouridae & 2 & $5.58^{*}$ & 1 & 0.09 & 2 & 0.21 \\
\hline
\end{tabular}

${ }^{*} p<0.1 \quad{ }^{* *} p<0.01 \quad{ }^{* * *} p<0.001$ 
Table 20: Correlation of family level macroinvertebrate metrics with annual average decomposition rate.

\begin{tabular}{lll}
\hline Invertebrate metrics $\dagger$ & $\mathrm{R}^{2}$ & $\mathrm{p}$-value \\
\hline WVSCl & 0.22 & $0.045^{*}$ \\
Num & 0.35 & $0.011^{*}$ \\
$\%$ EPT & 0.07 & 0.169 \\
EPT & 0.51 & $0.002^{* *}$ \\
$\%$ Tol & 0.25 & $0.031^{*}$ \\
$\%$ E & 0.25 & $0.036^{*}$ \\
MHI & 0.13 & 0.104 \\
\% Dom & 0.27 & $0.025^{*}$ \\
FRich & 0.43 & $0.005^{* *}$ \\
$\%$ Aci. Tol & -0.01 & 0.383 \\
$\%$ Al. Tol & 0.22 & $0.041^{*}$ \\
\hline
\end{tabular}

${ }^{*} p<0.1 \quad{ }^{* *} p<0.01 \quad{ }^{* * *} p<0.001$

† WVSCl, West Virginia stream condition index; Num, number of individual macroinvertebrates;

\% EPT, percent Ephemeroptera, Plecoptera and Trichoptera; EPT, Genus richness of Ephemeroptera, Plecoptera and Trichoptera; \% Tol, percent tolerant; \% E, percent Ephemeroptera; MHI, Modified hilsenhoff index; \% Dom, percent dominant; FRich, family richness; \% Aci.Tol, percent acid tolerant; \% Al.Tol, percent Al tolerant 
Table 21: Results of ANCOVA used to determine which microbial variables influenced annual average decomposition rates.

\begin{tabular}{lrlrlrl}
\hline & & & Microbial variable & & \multicolumn{2}{c}{$\begin{array}{l}\text { Microbial variable X site type } \\
\text { interaction }\end{array}$} \\
& d.f. & F-value & d.f. & F-value & d.f. & F-value \\
\hline Respiration & 2 & $15.65^{* *}$ & 1 & $12.37^{* *}$ & 2 & 2.65 \\
Ergosterol & 2 & $27.97^{* * *}$ & 1 & $14.46^{* *}$ & 2 & $12.14^{* *}$ \\
\hline \multicolumn{2}{c}{${ }^{*} p<0.1$} & ${ }^{* *} p<0.01$ & ${ }^{* * *} p<0.001$ &
\end{tabular}


Table 22: Models created from likely shredder, microbial and physical parameters and ranked by Akaike Information Criterion. Sample sized used in model estimation was 15.

\begin{tabular}{|c|c|c|c|c|c|c|}
\hline Model † & $\mathrm{K}$ & $\mathrm{AIC}$ & $\mathrm{AICc}$ & $\begin{array}{l}\text { Delta } \\
\text { AICc }\end{array}$ & $\begin{array}{l}\text { model } \\
\text { likelihood } \\
\text { AICc }\end{array}$ & $\begin{array}{l}\text { Akaike } \\
\text { weight } \\
\text { AlCc }\end{array}$ \\
\hline Respiration+ergosterol & 4.00 & -168.95 & -164.95 & 0.00 & 1.00 & 0.91 \\
\hline Voracious shredder+microbial resp + shredder rich+temp $+Q$ & 7.00 & -176.23 & -160.23 & 4.72 & 0.09 & 0.09 \\
\hline Total shredders+voracious shredder+shredder rich & 5.00 & -159.29 & -152.62 & 12.33 & 0.00 & 0.00 \\
\hline Voracious shredder+respiration+ ergosterol+shredder rich+temp $+Q$ & 8.00 & -175.07 & -151.07 & 13.88 & 0.00 & 0.00 \\
\hline Temp+Q & 4.00 & -154.90 & -150.90 & 14.05 & 0.00 & 0.00 \\
\hline Total shredders+voracious shredder+respiration+ ergosterol+shredder rich+temp+Q & 9.00 & -173.54 & -137.54 & 27.41 & 0.00 & 0.00 \\
\hline
\end{tabular}

$\dagger$ respiration, microbial respiration; ergosterol, ergosterol concentration; shredder rich, shredder richness; temp, water temperature; $Q$, stream discharge 
Equation 1: Most likely model to predict leaf litter decomposition rate as ranked by Akaike Information Criterion.

$$
k=-0.0326+0.0128(\text { resp })+0.0019(\text { ergosterol })
$$

$\mathrm{k}$, leaf litter decomposition rate; resp, microbial respiration; ergosterol, ergosterol concentration

Equation 2: Second most likely model to predict leaf litter decomposition rate as ranked by Akaike Information Criterion.

$k=-0.0525+0.00001($ vorachious $)+0.00928($ resp $)+0.00083($ shredder rich $)+0.00369($ temp $)+(0.00656(Q)$

k, leaf litter decomposition rate; voracious, voracious shredders; resp, microbial respiration; shredder rich, shredder richness; temp, stream temperature; $Q$, stream discharge 


\section{Catchment}
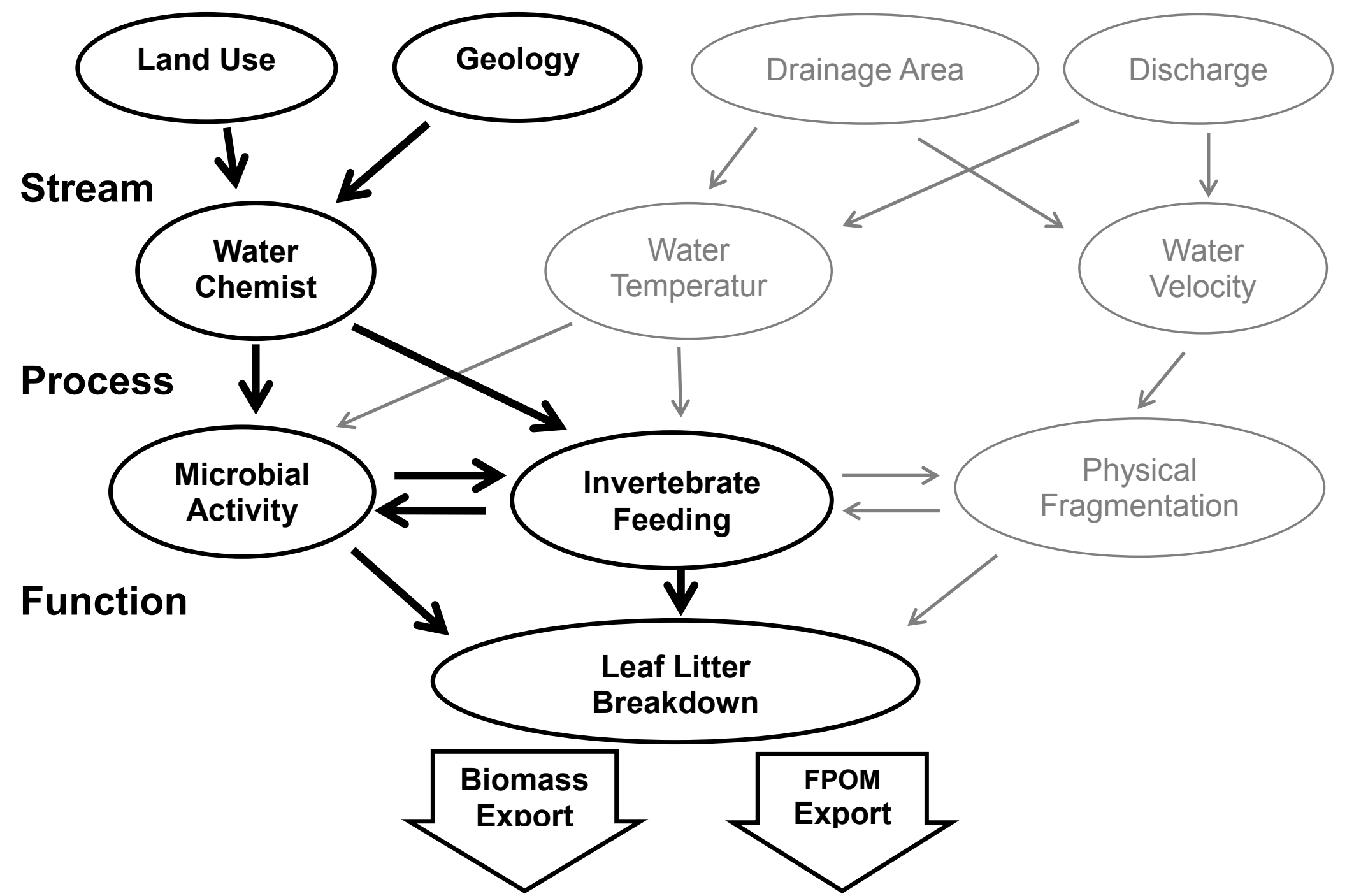

Figure 1: Hierarchical framework of factors controlling rates of leaf processing in streams, showing the abiotic and biotic interactions influencing leaf processing according to their levels of influence (modified from Royer and Minshall 2003). Bolded factors are the factors of interest in this study while greyed factors have been controlled for. 


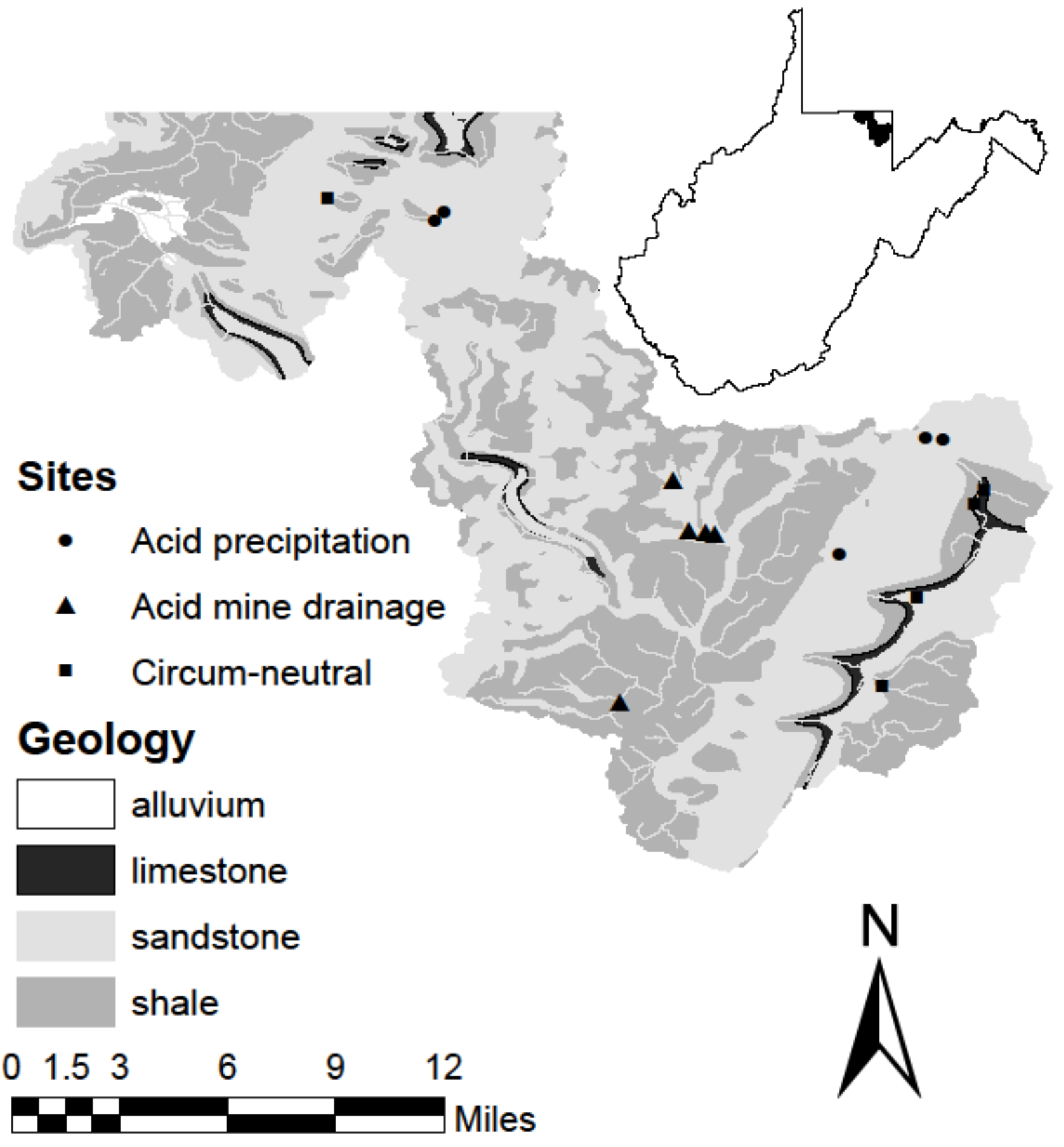

Figure 2: Bedrock geology of Muddy Creek and the Big Sandy Creek watersheds. 


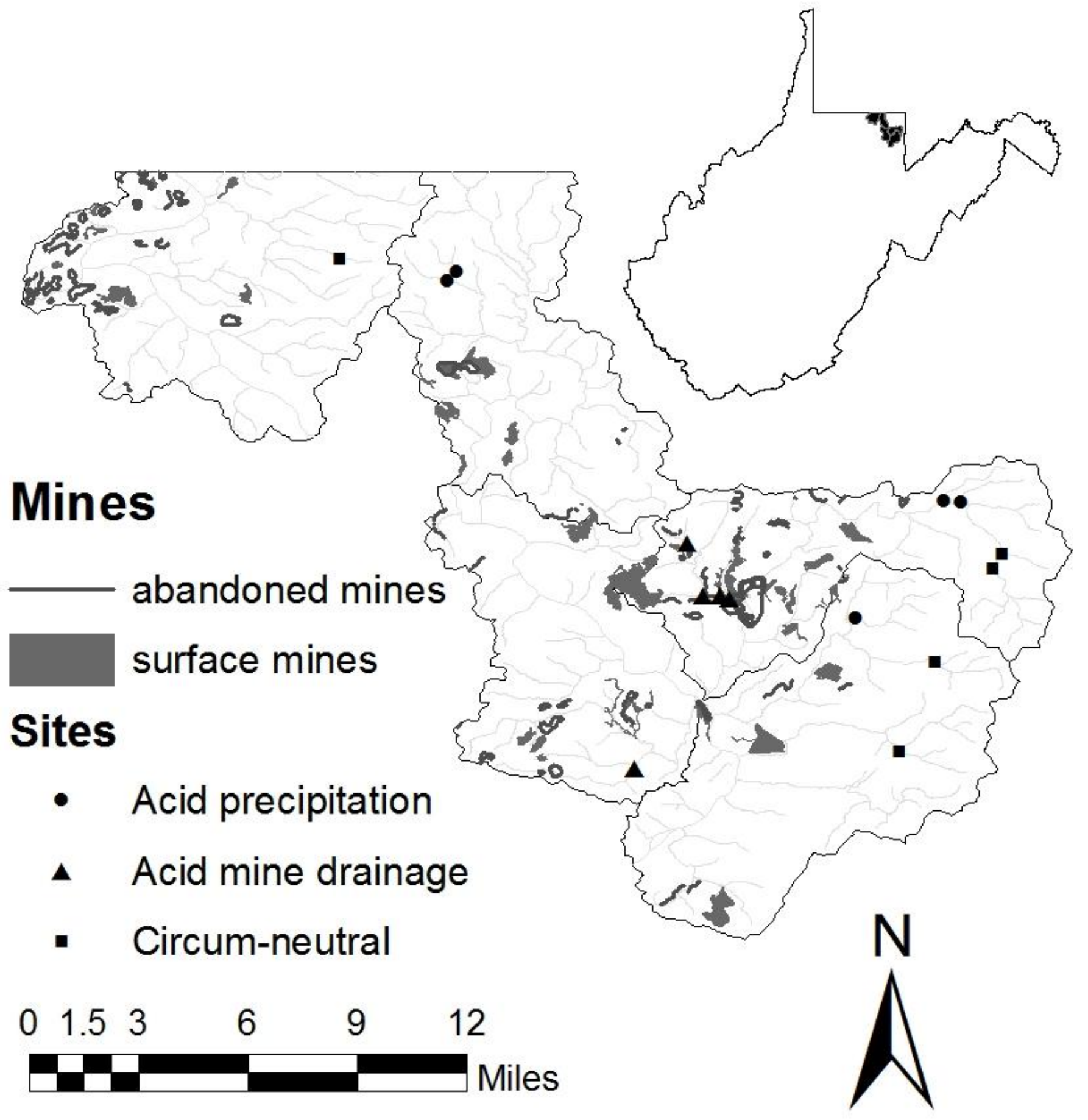

Figure 3: Surface mines and abandoned mines in the muddy Creek and Big Sandy Creek watersheds 


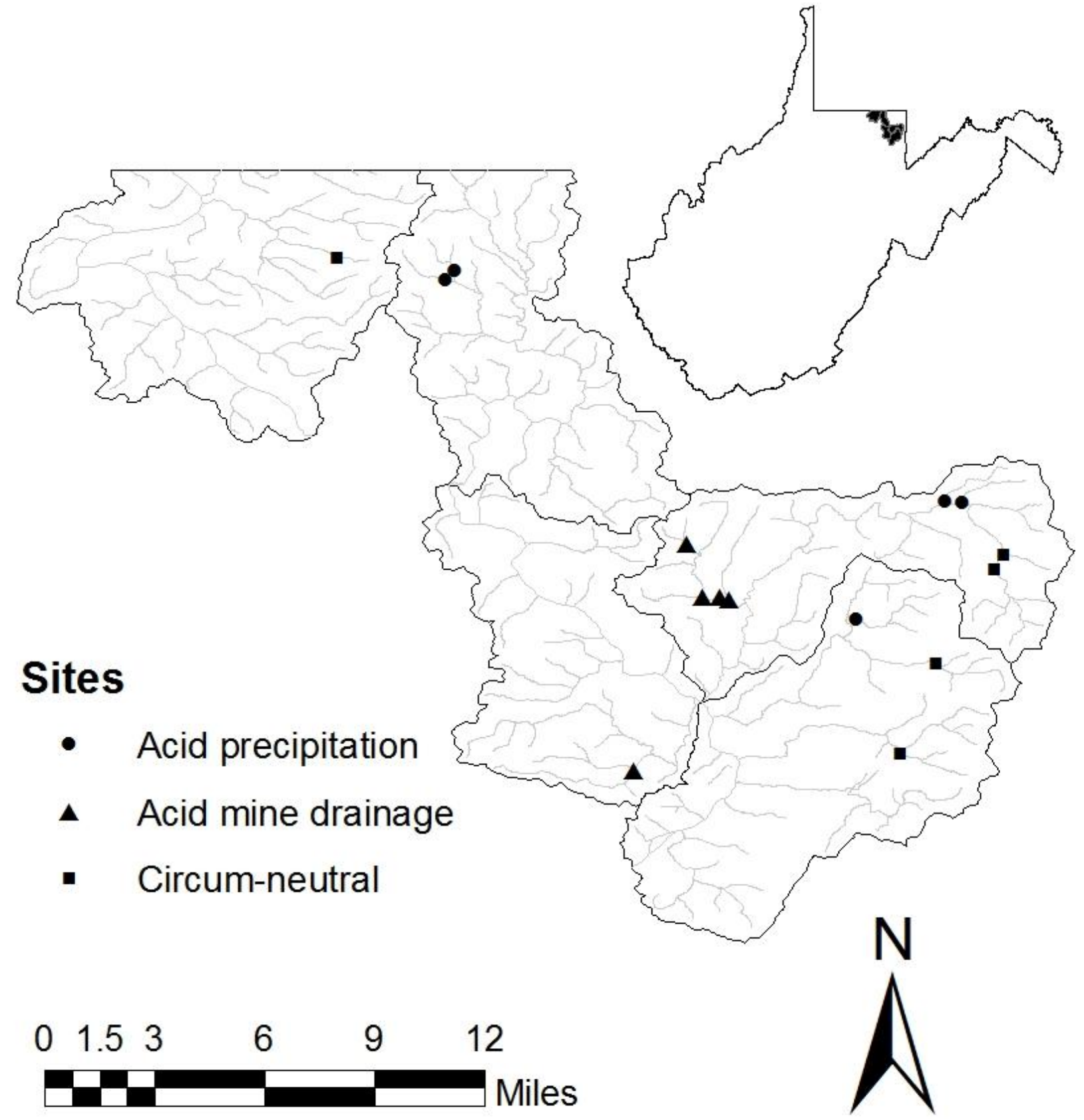

Figure 4: Location of study sites 

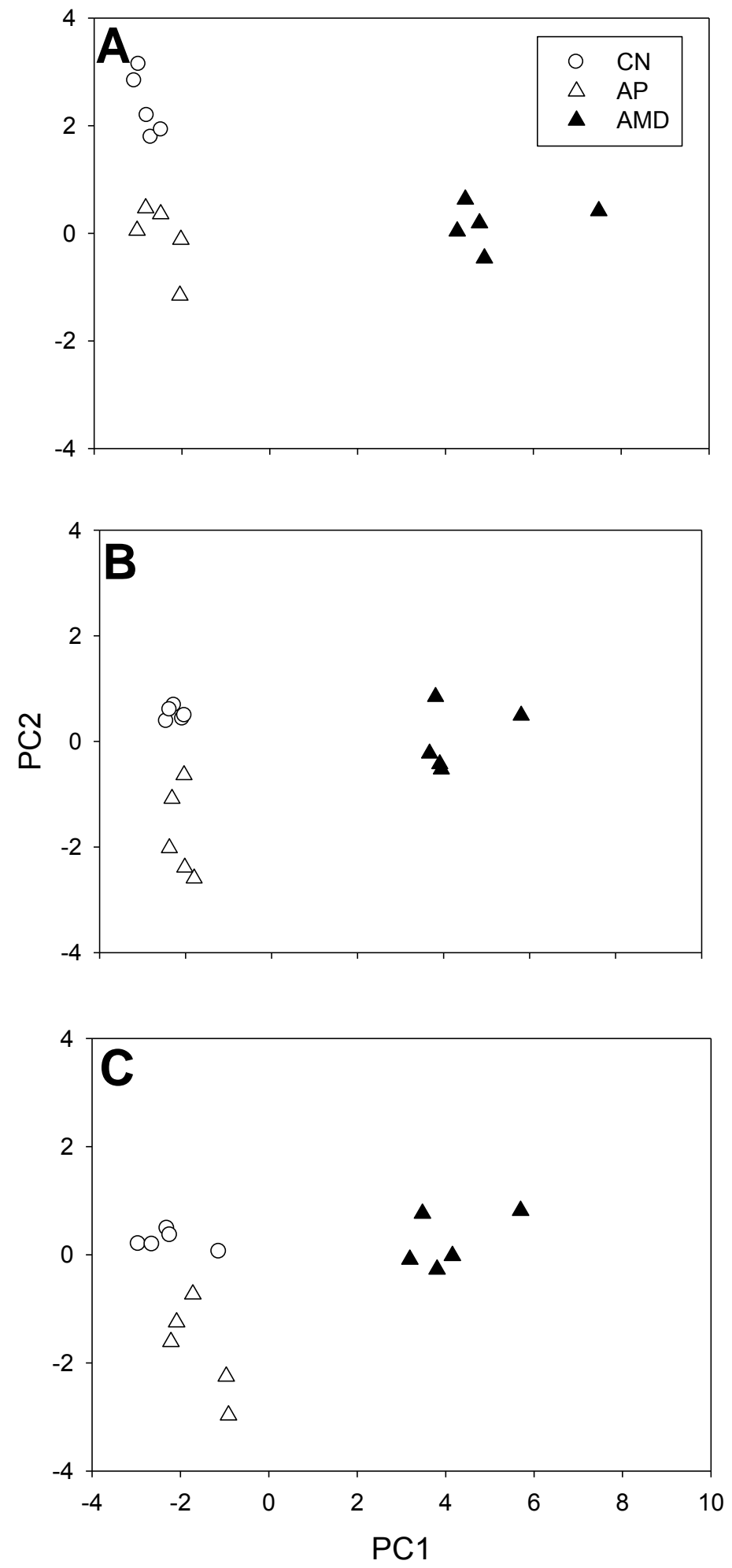

Figure 5: Bivariate scatter plot of principle component (PC) 1 and 2 scores of averaged water chemistry samples for each seasonal decomposition trial for each stream; summer $(A)$, winter (B), spring $(\mathrm{C})$. $C \mathrm{CN}=$ circumneutral; $\mathrm{AP}=$ acid precipitation; and $\mathrm{AMD}=$ acid mine drainage streams. For factors loading on PC1 and 2 refer to Table 5 


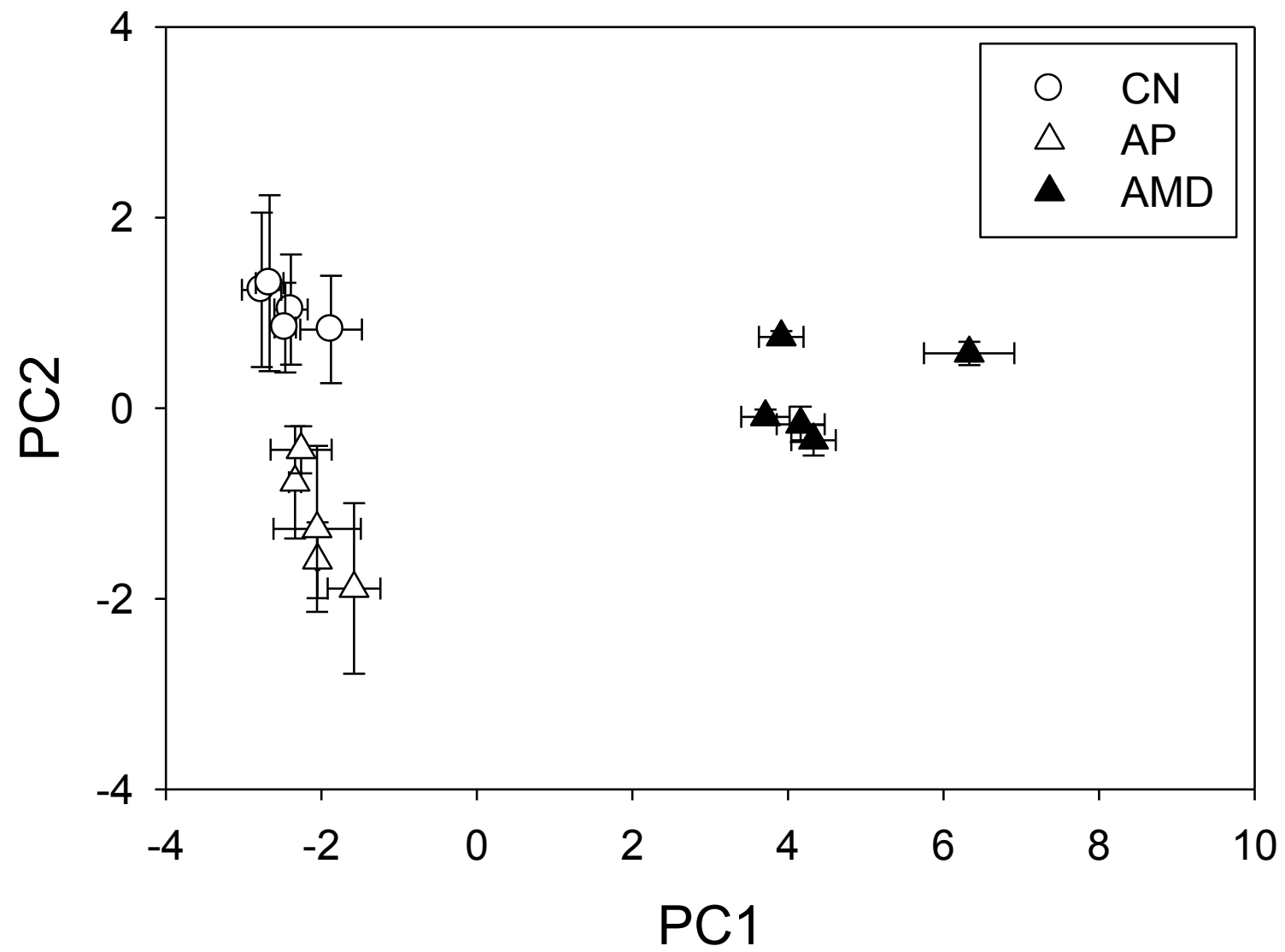

Figure 6: Bivariate scatter plot of the annual mean ( $\pm S E)$ principal component $(P C) 1$ and 2 scores of water chemistry samples for each stream. $\mathrm{CN}=$ circumneutral; $\mathrm{AP}=$ acid precipitation; and $\mathrm{AMD}=$ acid mine drainage streams. For factors loading on PC1 and 2 refer to Table 

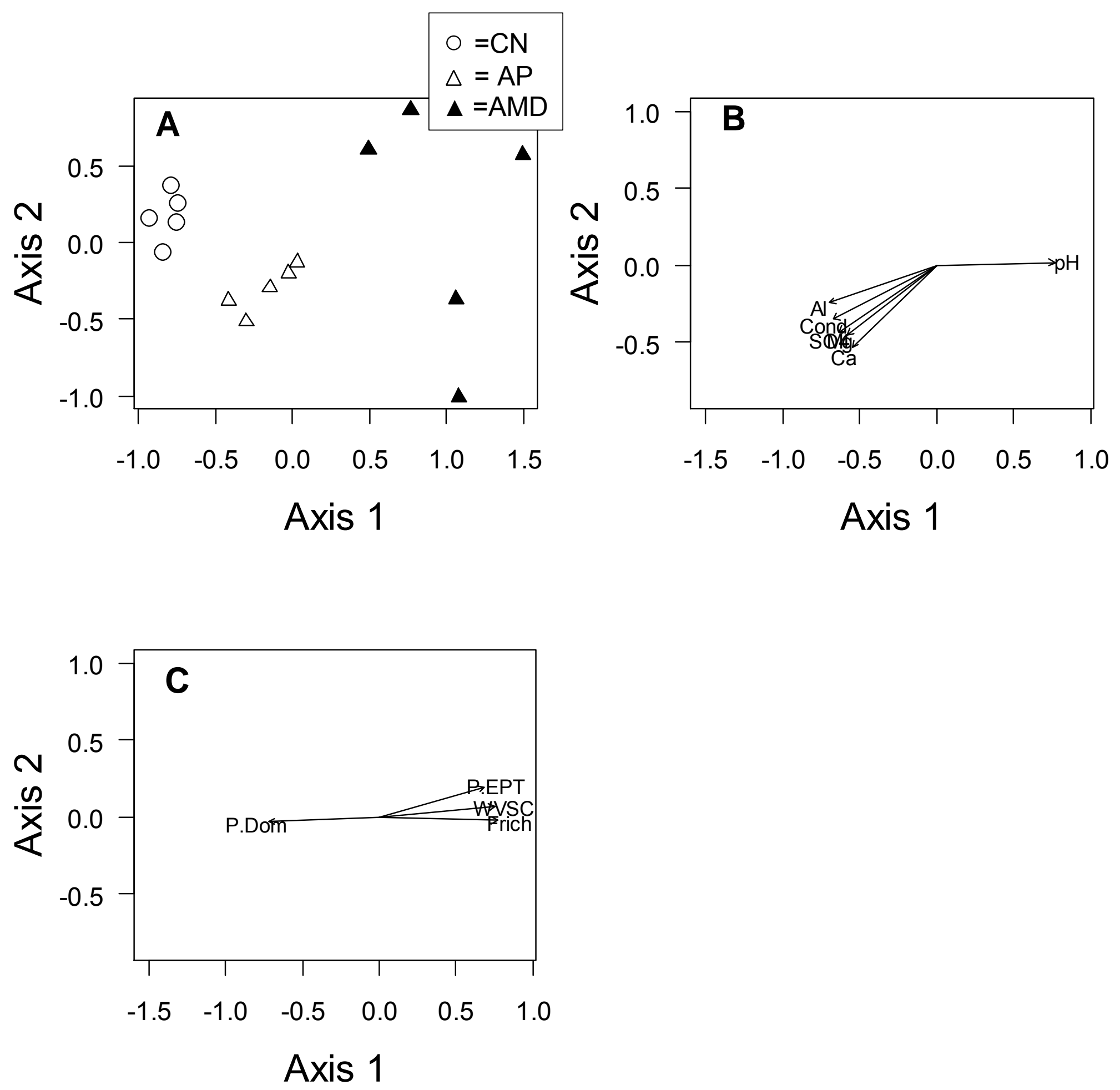

Figure 7: Nonmetric multidimensional scaling (NMDS) ordination of macroinvertebrate communities collected at each stream (A), environmental fit of the associated water chemistry variables $(B)$, and environmental fit of the associated macroinvertebrate metrics $(C)$. 


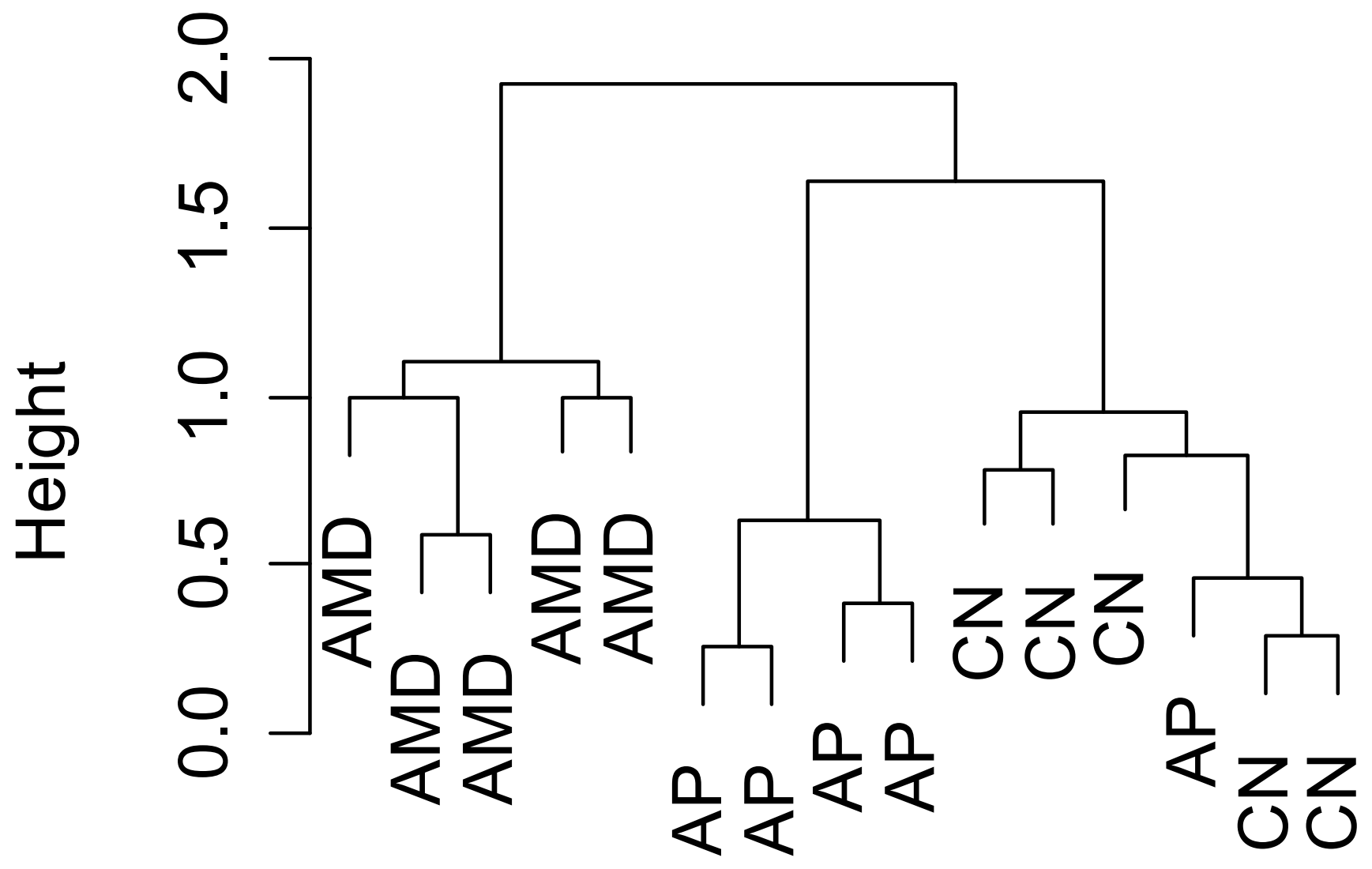

Figure 8: Cluster analysis of shredder community assemblages. $C N=$ circumneutral, AP = acid precipitation and $\mathrm{AMD}=$ acid mine drainage vegdist(shredders[, 4:28], method = "bray") hclust (*, "ward") 

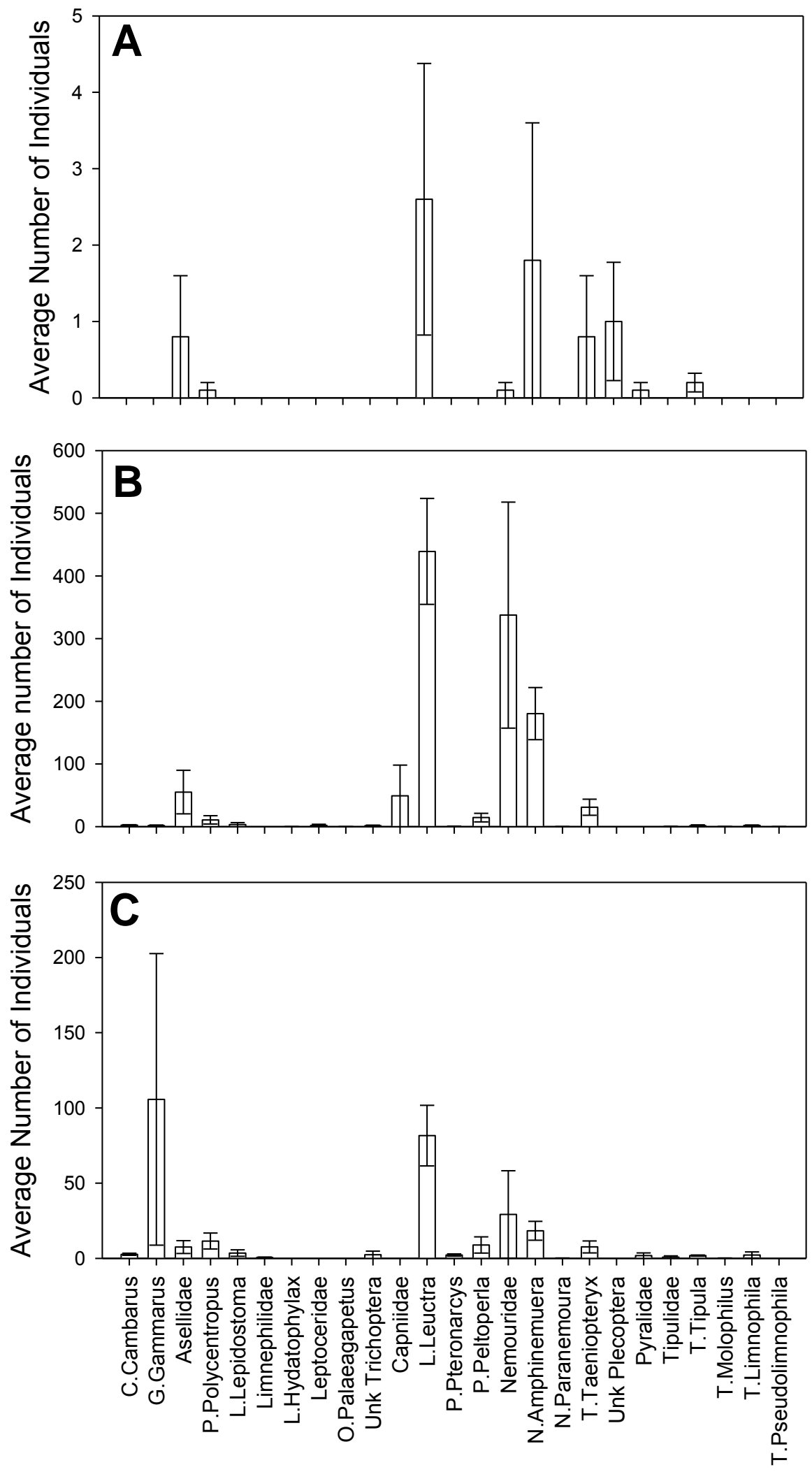

Figure 9: Mean $( \pm S E)$ number of individuals from a taxon contributing to the shredder functional feeding group for each stream type: acid mine drainage (A), acid precipitation (B), and circumneutral (C). 

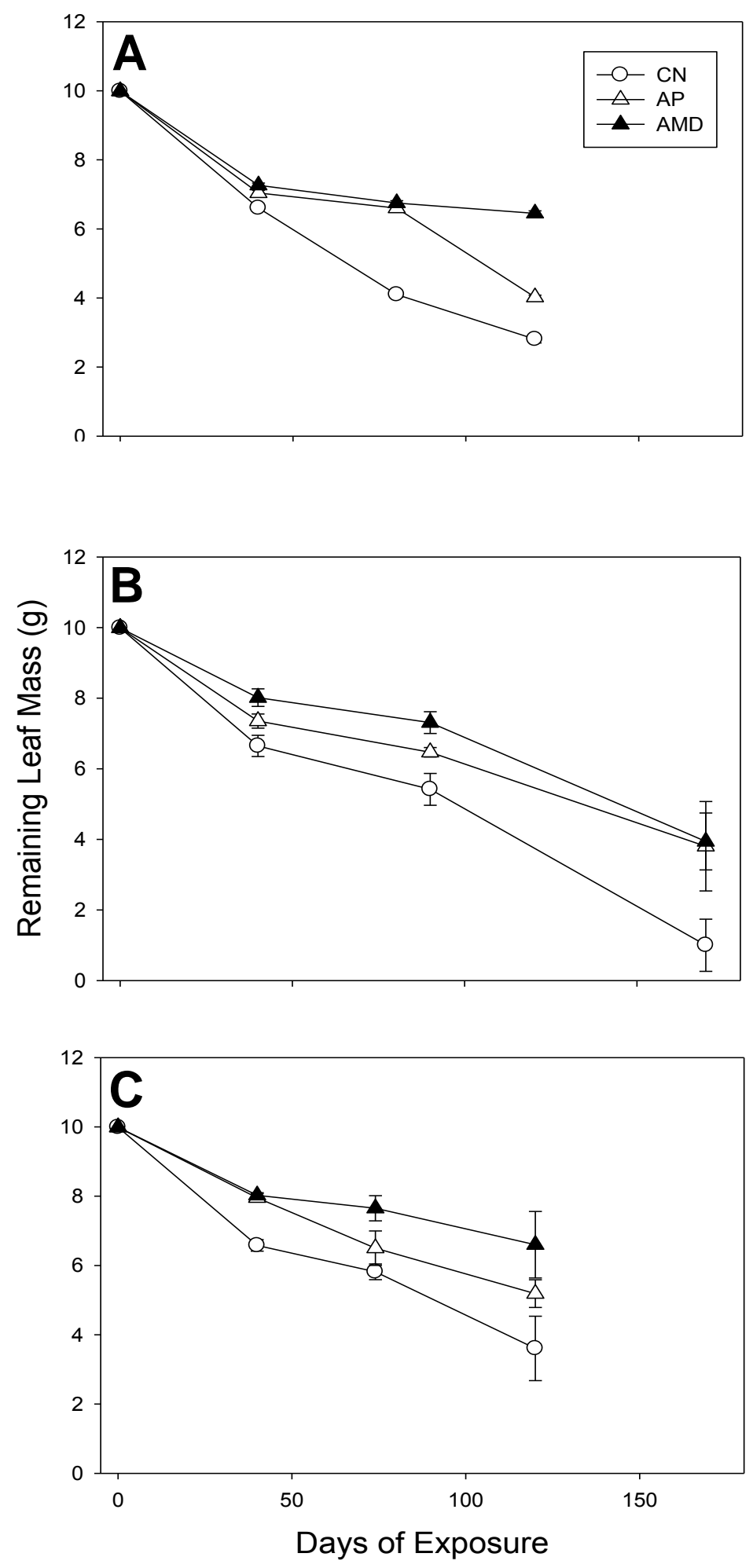

Figure 10: Mean ( $\pm S E)$ remaining leaf mass for each stream types, circumneutral $(C N)$, acid precipitation (AP), and acid mine drainage (AMD), for every decomposition trial; summer (A), winter $(B)$, and spring $(C)$. 


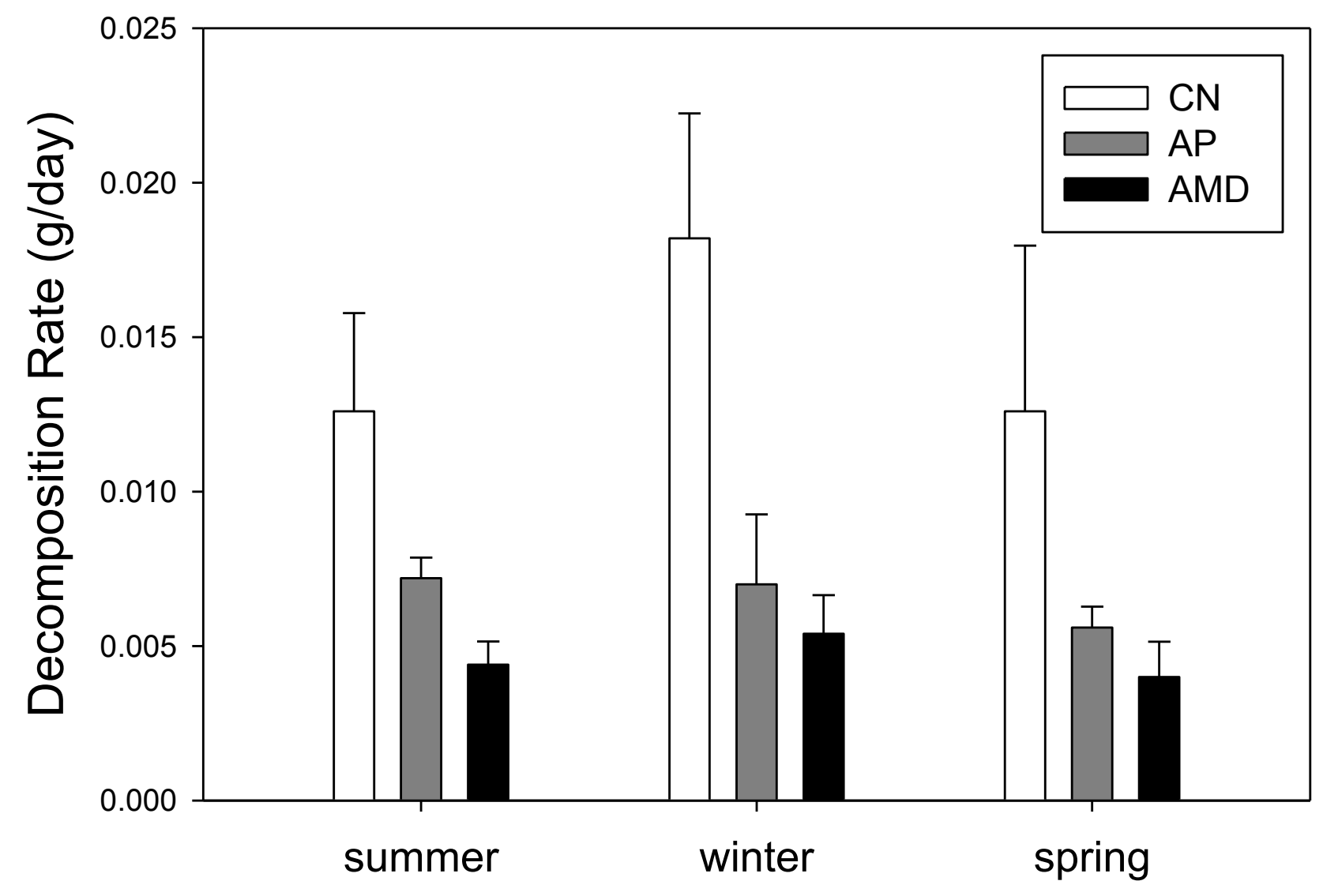

Figure 11: Mean (+SE) decomposition rate of oak leaves in circumneutral (CN), acid precipitation $(A P)$ and acid mine drainage (AMD) streams. Decomposition rates are from approximately 120 day seasonal decomposition trial for summer, winter, and spring. 


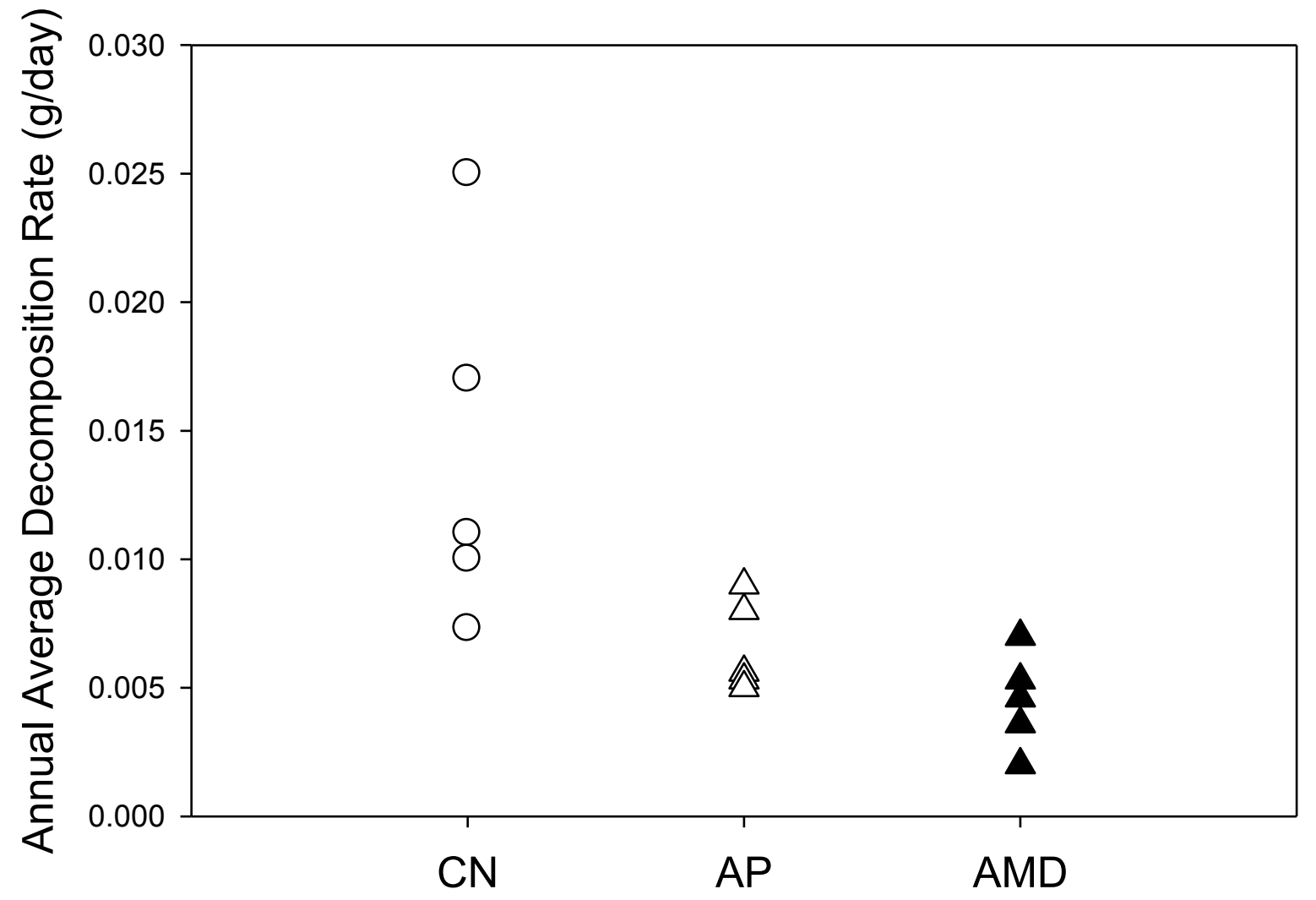

Figure 12: Annual average decomposition rates of each study stream organized by stream type. $\mathrm{CN}=$ circumneutral, $\mathrm{AP}=$ acid precipitation, and $\mathrm{AMD}=$ acid mine drainage . 

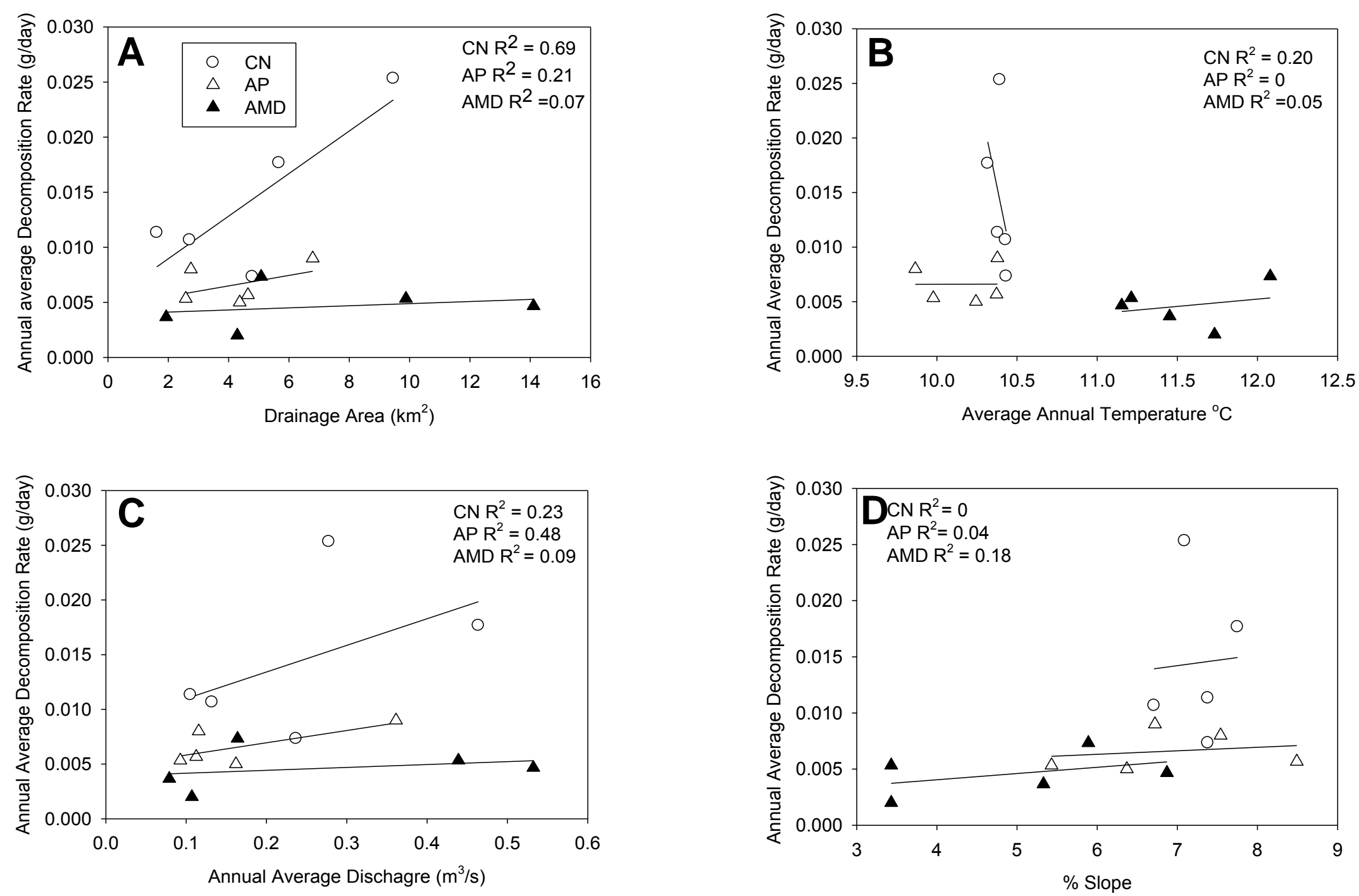

Figure 13: Relationship between the annual average decomposition rate and drainage area (A), annual average stream temperature $(B)$, annual average stream discharge (C), and percent slope (D). Linear regressions within each stream type are shown with the corresponding $\mathrm{R}^{2}$ value, where $\mathrm{CN}=$ circumneutral, $\mathrm{AP}=$ acid precipitation and $\mathrm{AMD}=$ acid mine drainage. 

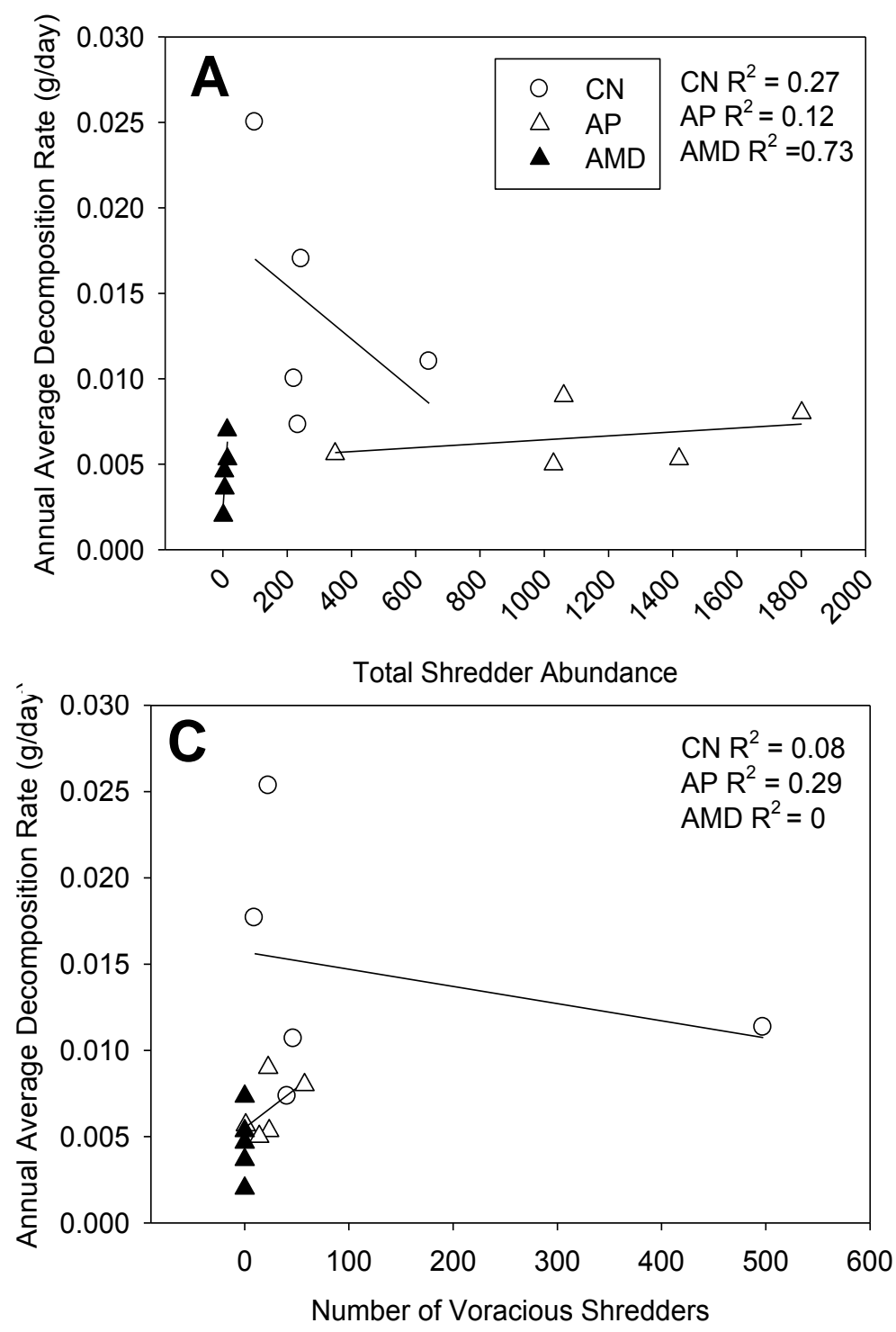
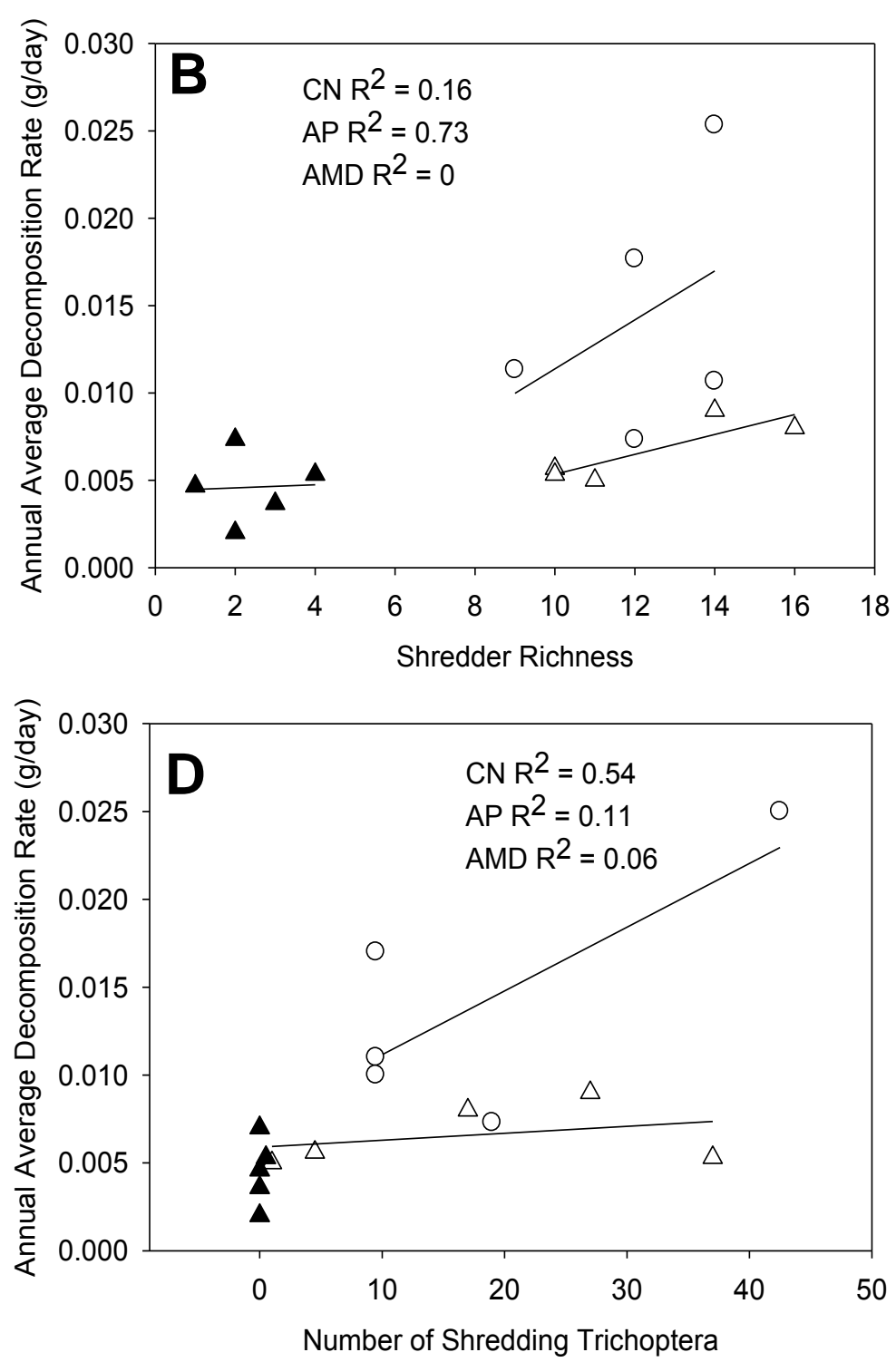

Figure 14: Relationship between annual average decomposition rates and total shredder abundance (A), shredder richness (B), voracious shredders $(C)$, number of shredding Trichoptera (D), number of shredding Plecoptera (E), number of shredding Tipulidae $(F)$, and number of Nemouridae $(G)$. Liner relationships within each stream type are shown with their corresponding $R^{2}$ value, where $\mathrm{CN}=$ circumneutral, $\mathrm{AP}=$ acid precipitation, and $\mathrm{AMD}=$ acid mine drainage 

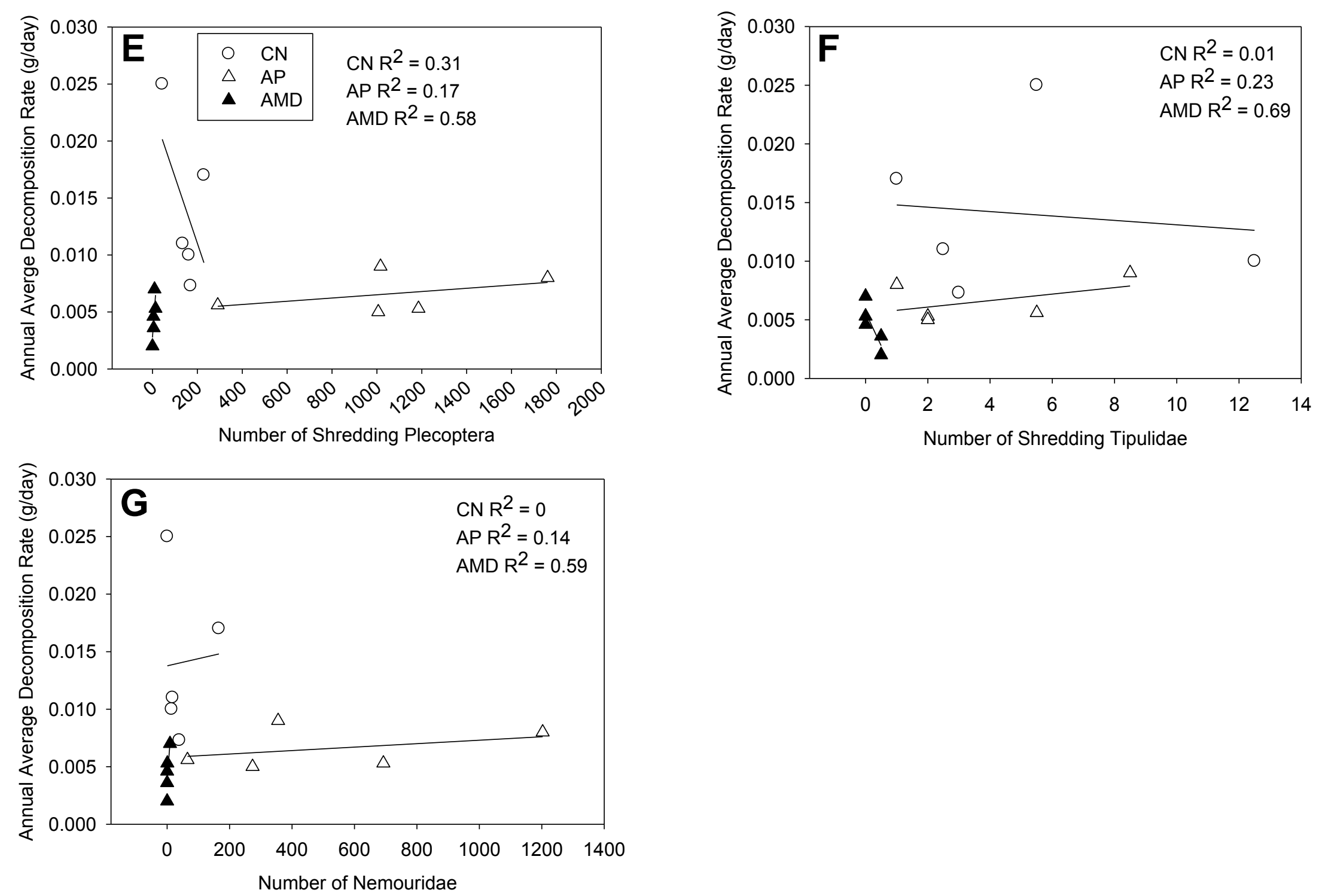

Figure 15 continued: Relationship between annual average decomposition rates and total shredder abundance (A),shredder richness (B), voracious shredders (C), number of shredding Trichoptera (D), number of shredding Plecoptera (E), number of shredding Tipulidae $(F)$, and number of Nemouridae $(G)$. Liner relationships within each stream type are shown with their corresponding $R^{2}$ value, where $\mathrm{CN}=$ circumneutral, $\mathrm{AP}=$ acid precipitation, and $\mathrm{AMD}=$ acid mine drainage 

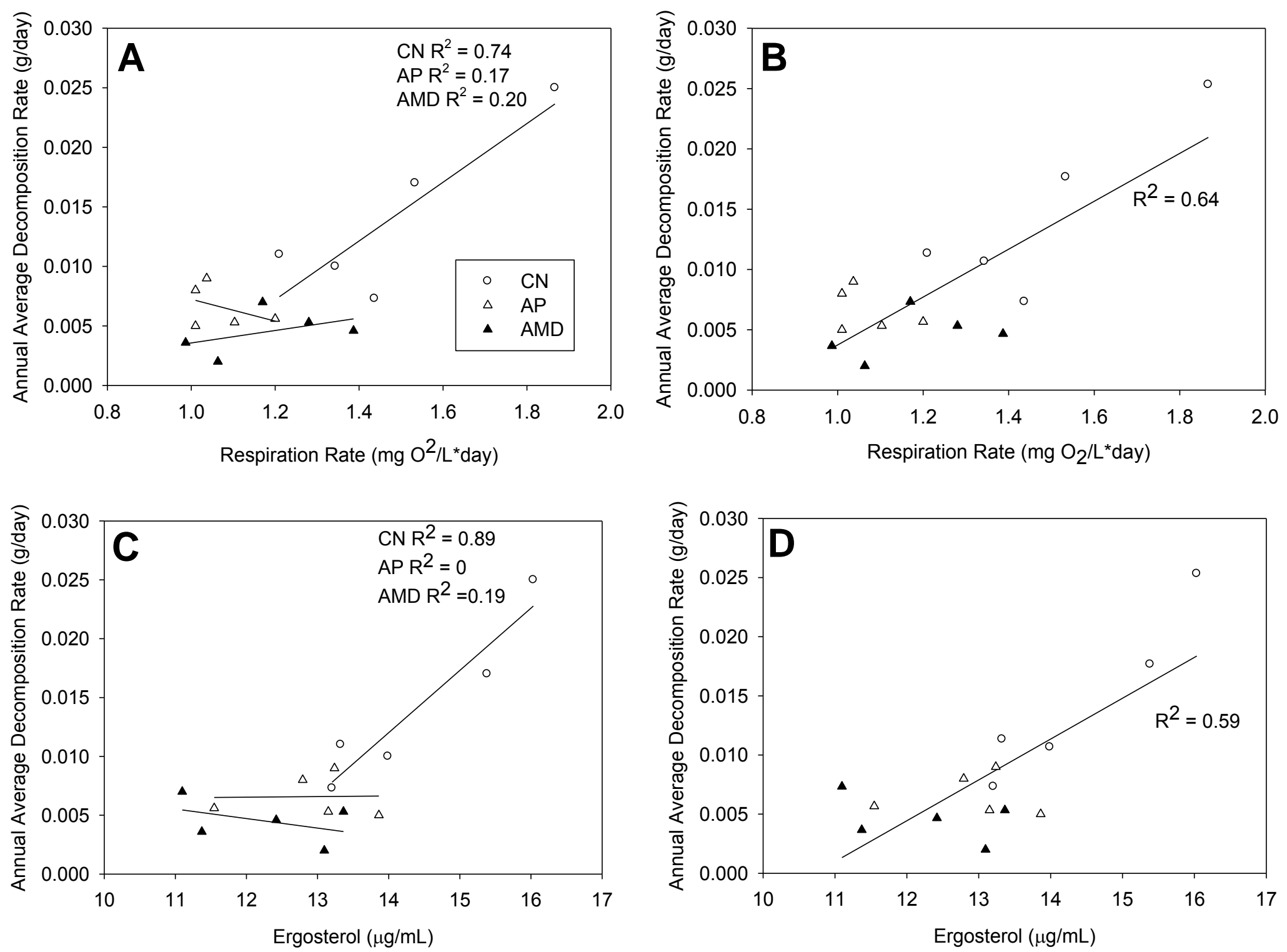

Figure 16: Relationships between annual average decomposition rate and microbial respiration rate $(A$ and $B)$ and ergosterol concentration $(C$ and $D)$. Linear relationships between decomposition and respiration rate $(A)$ and ergosterol concentration $(C)$ are shown with their corresponding $R^{2}$ value for each stream type, where $C N=$ circumneutral, $A P=$ acid precipitation, and $A M D=$ acid mine drainage. Correlations between decomposition and all respiration rates (B) and ergosterol concentrations (D) with corresponding $R^{2}$ values are also shown. 
Appendix I. Average number of individuals, percentage of assemblage and percentage of functional feeding group for each genus collected for each site type.

\begin{tabular}{|c|c|c|c|c|c|c|c|c|c|c|}
\hline \multirow{2}{*}{ Shredders } & & \multicolumn{3}{|c|}{ Circumneutral } & \multicolumn{3}{|c|}{ Acid precipitation } & \multicolumn{3}{|c|}{ Acid mine drainage } \\
\hline & & Average \# & $\%$ total & $\%$ shredders & Average \# & $\%$ total & $\%$ shredders & Average \# & $\%$ total & $\%$ shredders \\
\hline Decapoda* & & 2.70 & $0.1 \%$ & $0.9 \%$ & 2.30 & $0.1 \%$ & $0.2 \%$ & 0.00 & $0.0 \%$ & $0.0 \%$ \\
\hline Amphipoda* & & 105.70 & $4.9 \%$ & $36.6 \%$ & 1.60 & $0.1 \%$ & $0.1 \%$ & 0.00 & $0.0 \%$ & $0.0 \%$ \\
\hline Isopoda & & 7.50 & $0.3 \%$ & $2.6 \%$ & 55.10 & $3.0 \%$ & $4.9 \%$ & 0.80 & $0.8 \%$ & $10.7 \%$ \\
\hline \multicolumn{11}{|l|}{ Trichoptera } \\
\hline Polycentropodidae & Polycentropus & 11.50 & $0.3 \%$ & $4.0 \%$ & 10.70 & $0.4 \%$ & $0.9 \%$ & 0.10 & $0.0 \%$ & $1.3 \%$ \\
\hline Lepidostomatidae* & Lepidostoma & 3.50 & $0.1 \%$ & $1.2 \%$ & 3.20 & $0.1 \%$ & $0.3 \%$ & 0.00 & $0.0 \%$ & $0.0 \%$ \\
\hline \multirow[t]{2}{*}{ Limnephilidae* $^{*}$} & Hydatophylax & 0.00 & $0.0 \%$ & $0.0 \%$ & 0.10 & $0.0 \%$ & $0.0 \%$ & 0.00 & $0.0 \%$ & $0.0 \%$ \\
\hline & unknown & 0.60 & $0.0 \%$ & $0.2 \%$ & 0.00 & $0.0 \%$ & $0.0 \%$ & 0.00 & $0.0 \%$ & $0.0 \%$ \\
\hline Leptoceridae & unknown & 0.00 & $0.0 \%$ & $0.0 \%$ & 1.80 & $0.0 \%$ & $0.2 \%$ & 0.00 & $0.0 \%$ & $0.0 \%$ \\
\hline Odontoceridae & Palaeagapetus & 0.00 & $0.0 \%$ & $0.0 \%$ & 0.10 & $0.0 \%$ & $0.0 \%$ & 0.00 & $0.0 \%$ & $0.0 \%$ \\
\hline unknown & & 2.40 & $0.1 \%$ & $0.8 \%$ & 1.40 & $0.0 \%$ & $0.1 \%$ & 0.00 & $0.0 \%$ & $0.0 \%$ \\
\hline \multicolumn{11}{|l|}{ Plecoptera } \\
\hline Capniidae & unknown & 0.00 & $0.0 \%$ & $0.0 \%$ & 49.10 & $1.8 \%$ & $4.3 \%$ & 0.00 & $0.0 \%$ & $0.0 \%$ \\
\hline Leuctridae & Leuctra & 81.60 & $3.1 \%$ & $28.3 \%$ & 439.10 & $23.3 \%$ & $38.8 \%$ & 2.60 & $0.7 \%$ & $34.7 \%$ \\
\hline Pteronarcyidae* & Pteronarcys & 2.20 & $0.1 \%$ & $0.8 \%$ & 0.40 & $0.0 \%$ & $0.0 \%$ & 0.00 & $0.0 \%$ & $0.0 \%$ \\
\hline Peltoperlidae* & Peltoperla & 8.90 & $0.3 \%$ & $3.1 \%$ & 14.40 & $0.4 \%$ & $1.3 \%$ & 0.00 & $0.0 \%$ & $0.0 \%$ \\
\hline \multirow[t]{3}{*}{ Nemouridae } & Amphinemuera & 18.30 & $0.7 \%$ & $6.3 \%$ & 180.30 & $8.5 \%$ & $15.9 \%$ & 1.80 & $1.9 \%$ & $24.0 \%$ \\
\hline & Paranemoura & 0.10 & $0.0 \%$ & $0.0 \%$ & 0.10 & $0.0 \%$ & $0.0 \%$ & 0.00 & $0.0 \%$ & $0.0 \%$ \\
\hline & unknown & 29.20 & $1.0 \%$ & $10.1 \%$ & 337.50 & $9.4 \%$ & $29.8 \%$ & 0.10 & $0.0 \%$ & $1.3 \%$ \\
\hline Taeniopterygidae & Taeniopteryx & 7.60 & $0.2 \%$ & $2.6 \%$ & 30.90 & $1.5 \%$ & $2.7 \%$ & 0.80 & $0.2 \%$ & $10.7 \%$ \\
\hline unknown & & 0.00 & $0.0 \%$ & $0.0 \%$ & 0.00 & $0.0 \%$ & $0.0 \%$ & 1.00 & $0.4 \%$ & $13.3 \%$ \\
\hline Lepidoptera & & & & & & & & & & \\
\hline $\begin{array}{l}\text { Pyralidae } \\
\text { Diptera }\end{array}$ & unknown & 1.80 & $0.1 \%$ & $0.6 \%$ & 0.00 & $0.0 \%$ & $0.0 \%$ & 0.10 & $0.2 \%$ & $1.3 \%$ \\
\hline \multirow[t]{4}{*}{ Tipulidae } & Tipula & 1.80 & $0.1 \%$ & $0.6 \%$ & 1.50 & $0.1 \%$ & $0.1 \%$ & 0.20 & $0.3 \%$ & $2.7 \%$ \\
\hline & Molophilus & 0.10 & $0.0 \%$ & $0.0 \%$ & 0.20 & $0.0 \%$ & $0.0 \%$ & 0.00 & $0.0 \%$ & $0.0 \%$ \\
\hline & Limnophila & 2.20 & $0.1 \%$ & $0.8 \%$ & 1.80 & $0.2 \%$ & $0.2 \%$ & 0.00 & $0.0 \%$ & $0.0 \%$ \\
\hline & Pseudolimnophila & 0.00 & $0.0 \%$ & $0.0 \%$ & 0.10 & $0.0 \%$ & $0.0 \%$ & 0.00 & $0.0 \%$ & $0.0 \%$ \\
\hline
\end{tabular}

${ }^{*}$ Voracious shredders 


\section{Appendix I. Continued}

\begin{tabular}{|c|c|c|c|c|c|c|c|c|c|c|}
\hline \multirow{3}{*}{ Scrappers } & & \multicolumn{3}{|c|}{ Circumneutral } & \multicolumn{3}{|c|}{ Acid precipitation } & \multicolumn{3}{|c|}{ Acid mine drainage } \\
\hline & & \multirow{3}{*}{ Average \# } & \multirow{3}{*}{$\%$ total } & \multirow[b]{2}{*}{$\%$ scraper } & \multirow[b]{2}{*}{ Average \# } & \multirow[b]{2}{*}{$\%$ total } & \multirow[b]{2}{*}{$\%$ scrapers } & \multirow[b]{2}{*}{ Average \# } & \multirow[b]{2}{*}{$\%$ total } & \multirow[b]{2}{*}{$\%$ scraper } \\
\hline & & & & & & & & & & \\
\hline \multicolumn{9}{|l|}{ Ephemeroptera } & & \\
\hline \multirow[t]{4}{*}{ Heptageniidae } & Epeorus & 411.30 & $14.5 \%$ & $37.9 \%$ & 3.30 & $0.2 \%$ & $2.7 \%$ & 0.00 & $0.0 \%$ & $0.0 \%$ \\
\hline & Stenonema & 28.10 & $0.9 \%$ & $2.6 \%$ & 2.00 & $0.2 \%$ & $1.6 \%$ & 0.00 & $0.0 \%$ & $0.0 \%$ \\
\hline & Cinygmula & 16.80 & $0.5 \%$ & $1.5 \%$ & 0.00 & $0.0 \%$ & $0.0 \%$ & 0.10 & $0.0 \%$ & $8.3 \%$ \\
\hline & unknown & 7.10 & $0.2 \%$ & $0.7 \%$ & 0.10 & $0.0 \%$ & $0.1 \%$ & 0.00 & $0.0 \%$ & $0.0 \%$ \\
\hline Ephemerellidae & Drunella & 45.00 & $1.5 \%$ & $4.1 \%$ & 0.80 & $0.1 \%$ & $0.7 \%$ & 0.00 & $0.0 \%$ & $0.0 \%$ \\
\hline \multicolumn{11}{|l|}{ Trichoptera } \\
\hline Limnephilidae & Goera & 0.30 & $0.0 \%$ & $0.0 \%$ & 0.00 & $0.0 \%$ & $0.0 \%$ & 0.00 & $0.0 \%$ & $0.0 \%$ \\
\hline Hydroptilidae & Hydroptila & 0.10 & $0.0 \%$ & $0.0 \%$ & 0.00 & $0.0 \%$ & $0.0 \%$ & 0.00 & $0.0 \%$ & $0.0 \%$ \\
\hline \multirow[t]{2}{*}{ Glossosomatidae } & Agapetus & 27.20 & $1.0 \%$ & $2.5 \%$ & 1.70 & $0.0 \%$ & $1.4 \%$ & 0.00 & $0.0 \%$ & $0.0 \%$ \\
\hline & Glossosoma & 0.30 & $0.0 \%$ & $0.0 \%$ & 0.00 & $0.0 \%$ & $0.0 \%$ & 0.00 & $0.0 \%$ & $0.0 \%$ \\
\hline Uenoidae & Neophylax & 52.00 & $1.8 \%$ & $4.8 \%$ & 16.10 & $0.7 \%$ & $13.1 \%$ & 0.10 & $0.0 \%$ & $8.3 \%$ \\
\hline \multicolumn{11}{|l|}{ Coleoptera } \\
\hline \multirow[t]{4}{*}{ Elmidae } & Optioservus & 300.20 & $8.6 \%$ & $27.7 \%$ & 62.20 & $2.1 \%$ & $50.8 \%$ & 1.00 & $0.3 \%$ & $83.3 \%$ \\
\hline & Promoresia & 59.20 & $1.3 \%$ & $5.5 \%$ & 0.00 & $0.0 \%$ & $0.0 \%$ & 0.00 & $0.0 \%$ & $0.0 \%$ \\
\hline & Oulimnius & 95.30 & $3.0 \%$ & $8.8 \%$ & 36.30 & $1.8 \%$ & $29.6 \%$ & 0.00 & $0.0 \%$ & $0.0 \%$ \\
\hline & Stenelmis & 1.60 & $0.0 \%$ & $0.1 \%$ & 0.00 & $0.0 \%$ & $0.0 \%$ & 0.00 & $0.0 \%$ & $0.0 \%$ \\
\hline \multirow[t]{2}{*}{ Psephenidae } & Ectopria & 11.20 & $0.3 \%$ & $1.0 \%$ & 0.00 & $0.0 \%$ & $0.0 \%$ & 0.00 & $0.0 \%$ & $0.0 \%$ \\
\hline & Psephenus & 0.20 & $0.0 \%$ & $0.0 \%$ & 0.00 & $0.0 \%$ & $0.0 \%$ & 0.00 & $0.0 \%$ & $0.0 \%$ \\
\hline \multicolumn{11}{|l|}{ Diptera } \\
\hline Blephariceridae & Blepharicera & 28.50 & $0.9 \%$ & $2.6 \%$ & 0.00 & $0.0 \%$ & $0.0 \%$ & 0.00 & $0.0 \%$ & $0.0 \%$ \\
\hline
\end{tabular}




\section{Appendix I. Continued}

\begin{tabular}{|c|c|c|c|c|c|c|c|c|c|c|}
\hline \multirow{3}{*}{ Predators } & & \multicolumn{3}{|c|}{ Circumneutral } & \multicolumn{3}{|c|}{ Acid precipitation } & \multicolumn{3}{|c|}{ Acid mine drainage } \\
\hline & & \multirow{3}{*}{ Average \# } & \multirow{3}{*}{$\%$ total } & \multirow[b]{2}{*}{$\%$ predators } & \multirow[b]{2}{*}{ Average \# } & \multirow[b]{2}{*}{$\%$ total } & \multirow[b]{2}{*}{$\%$ predators } & \multirow[b]{2}{*}{ Average \# } & \multirow[b]{2}{*}{$\%$ total } & \multirow[b]{2}{*}{$\%$ predators } \\
\hline & & & & & & & & & & \\
\hline \multicolumn{9}{|l|}{ Trichoptera } & & \\
\hline Rhyacophilidae & Rhyacophilla & 33.80 & $1.2 \%$ & $11.8 \%$ & 77.80 & $3.3 \%$ & $39.7 \%$ & 1.10 & $0.4 \%$ & $5.3 \%$ \\
\hline \multicolumn{11}{|l|}{ Plecoptera } \\
\hline \multirow[t]{4}{*}{ Chloroperlidae } & Utaperla & 56.40 & $1.7 \%$ & $19.8 \%$ & 5.30 & $0.1 \%$ & $2.7 \%$ & 0.00 & $0.0 \%$ & $0.0 \%$ \\
\hline & Sweltsa & 22.50 & $0.9 \%$ & $7.9 \%$ & 0.00 & $0.0 \%$ & $0.0 \%$ & 0.00 & $0.0 \%$ & $0.0 \%$ \\
\hline & Alloperla & 0.00 & $0.0 \%$ & $0.0 \%$ & 1.60 & $0.1 \%$ & $0.8 \%$ & 0.00 & $0.0 \%$ & $0.0 \%$ \\
\hline & unknown & 0.40 & $0.0 \%$ & $0.1 \%$ & 0.80 & $0.0 \%$ & $0.4 \%$ & 0.30 & $0.1 \%$ & $1.4 \%$ \\
\hline \multirow[t]{4}{*}{ Perlidae } & Acroneuria & 14.60 & $0.5 \%$ & $5.1 \%$ & 1.10 & $0.0 \%$ & $0.6 \%$ & 0.00 & $0.0 \%$ & $0.0 \%$ \\
\hline & Eccoptura & 0.50 & $0.0 \%$ & $0.2 \%$ & 0.10 & $0.0 \%$ & $0.1 \%$ & 0.00 & $0.0 \%$ & $0.0 \%$ \\
\hline & Beloneuria & 0.80 & $0.0 \%$ & $0.3 \%$ & 0.00 & $0.0 \%$ & $0.0 \%$ & 0.00 & $0.0 \%$ & $0.0 \%$ \\
\hline & unknown & 6.40 & $0.2 \%$ & $2.2 \%$ & 0.90 & $0.0 \%$ & $0.5 \%$ & 0.00 & $0.0 \%$ & $0.0 \%$ \\
\hline \multirow[t]{7}{*}{ Perlodidae } & Isoperla & 2.80 & $0.1 \%$ & $1.0 \%$ & 1.60 & $0.1 \%$ & $0.8 \%$ & 0.00 & $0.0 \%$ & $0.0 \%$ \\
\hline & Diura & 0.50 & $0.0 \%$ & $0.2 \%$ & 0.00 & $0.0 \%$ & $0.0 \%$ & 0.00 & $0.0 \%$ & $0.0 \%$ \\
\hline & Cultus & 20.50 & $0.7 \%$ & $7.2 \%$ & 0.20 & $0.0 \%$ & $0.1 \%$ & 0.00 & $0.0 \%$ & $0.0 \%$ \\
\hline & Remenus & 25.10 & $0.7 \%$ & $8.8 \%$ & 0.00 & $0.0 \%$ & $0.0 \%$ & 0.00 & $0.0 \%$ & $0.0 \%$ \\
\hline & Yugus & 2.70 & $0.1 \%$ & $0.9 \%$ & 0.00 & $0.0 \%$ & $0.0 \%$ & 0.00 & $0.0 \%$ & $0.0 \%$ \\
\hline & Diploperla & 1.30 & $0.0 \%$ & $0.5 \%$ & 2.30 & $0.4 \%$ & $1.2 \%$ & 0.80 & $0.2 \%$ & $3.8 \%$ \\
\hline & unknown & 10.10 & $0.3 \%$ & $3.5 \%$ & 7.60 & $0.4 \%$ & $3.9 \%$ & 0.00 & $0.0 \%$ & $0.0 \%$ \\
\hline \multicolumn{11}{|l|}{ Odonata } \\
\hline \multicolumn{11}{|l|}{ Coleoptera } \\
\hline Hydrophilidae & unknown & 0.00 & $0.0 \%$ & $0.0 \%$ & 0.00 & $0.0 \%$ & $0.0 \%$ & 0.80 & $0.3 \%$ & $3.8 \%$ \\
\hline
\end{tabular}




\section{Appendix I. Continued}

\begin{tabular}{|c|c|c|c|c|c|c|c|c|c|c|}
\hline \multirow{3}{*}{\multicolumn{2}{|c|}{ Predators Continued }} & \multicolumn{3}{|c|}{ Circumneutral } & \multicolumn{3}{|c|}{ Acid precipitation } & \multicolumn{3}{|c|}{ Acid mine drainage } \\
\hline & & \multirow{3}{*}{ Average \# } & \multirow{3}{*}{$\%$ total } & \multirow[b]{2}{*}{$\%$ predators } & \multirow[b]{2}{*}{ Average \# } & \multirow[b]{2}{*}{$\%$ total } & \multirow[b]{2}{*}{$\%$ predators } & \multirow[b]{2}{*}{ Average \# } & \multirow[b]{2}{*}{$\%$ total } & \multirow[b]{2}{*}{$\%$ predators } \\
\hline & & & & & & & & & & \\
\hline \multicolumn{9}{|l|}{ Megaloptera } & & \\
\hline \multirow[t]{2}{*}{ Corydalidae } & Nigronia & 2.50 & $0.1 \%$ & $0.9 \%$ & 2.40 & $0.2 \%$ & $1.2 \%$ & 0.60 & $0.2 \%$ & $2.9 \%$ \\
\hline & Corydalus & 0.00 & $0.0 \%$ & $0.0 \%$ & 0.50 & $0.0 \%$ & $0.3 \%$ & 0.00 & $0.0 \%$ & $0.0 \%$ \\
\hline Sialidae & Sialis & 0.10 & $0.0 \%$ & $0.0 \%$ & 0.10 & $0.0 \%$ & $0.1 \%$ & 1.40 & $0.4 \%$ & $6.7 \%$ \\
\hline \multicolumn{11}{|l|}{ Diptera } \\
\hline \multirow[t]{2}{*}{ Tipulidae } & Hexatoma & 17.00 & $0.5 \%$ & $6.0 \%$ & 0.40 & $0.0 \%$ & $0.2 \%$ & 0.00 & $0.0 \%$ & $0.0 \%$ \\
\hline & Dicranota & 4.90 & $0.1 \%$ & $1.7 \%$ & 3.90 & $0.2 \%$ & $2.0 \%$ & 0.00 & $0.0 \%$ & $0.0 \%$ \\
\hline Dolichopodidae & unknown & 0.10 & $0.0 \%$ & $0.0 \%$ & 0.00 & $0.0 \%$ & $0.0 \%$ & 0.00 & $0.0 \%$ & $0.0 \%$ \\
\hline Athericidae & Atherix & 1.80 & $0.1 \%$ & $0.6 \%$ & 0.00 & $0.0 \%$ & $0.0 \%$ & 0.00 & $0.0 \%$ & $0.0 \%$ \\
\hline \multirow[t]{2}{*}{ Empididae } & Chelifera & 36.70 & $1.2 \%$ & $12.9 \%$ & 30.20 & $1.2 \%$ & $15.4 \%$ & 6.60 & $2.1 \%$ & $31.7 \%$ \\
\hline & Hemerodromia & 0.00 & $0.0 \%$ & $0.0 \%$ & 0.20 & $0.0 \%$ & $0.1 \%$ & 0.00 & $0.0 \%$ & $0.0 \%$ \\
\hline Ceratapagonidae & Bezzia & 12.90 & $0.4 \%$ & $4.5 \%$ & 23.40 & $1.1 \%$ & $11.9 \%$ & 6.70 & $2.6 \%$ & $32.2 \%$ \\
\hline chironimidae & Tanypodinae & 6.60 & $0.2 \%$ & $2.3 \%$ & 35.80 & $1.3 \%$ & $18.2 \%$ & 2.50 & $3.1 \%$ & $12.0 \%$ \\
\hline
\end{tabular}




\section{Appendix I. Continued}

\begin{tabular}{|c|c|c|c|c|c|c|c|c|c|c|}
\hline \multirow{3}{*}{ Collectors } & & \multicolumn{3}{|c|}{ Circumneutral } & \multicolumn{3}{|c|}{ Acid precipitation } & \multicolumn{3}{|c|}{ Acid mine drainage } \\
\hline & & & & & & & & & & \\
\hline & & Average \# & $\%$ total & $\%$ collectors & Average \# & $\%$ total & $\%$ collectors & Average \# & $\%$ total & $\%$ collectors \\
\hline Oligochaeta & & 24.40 & $0.8 \%$ & $1.7 \%$ & 74.70 & $3.4 \%$ & $6.7 \%$ & 0.00 & $0.0 \%$ & $0.0 \%$ \\
\hline Clams & & 0.30 & $0.0 \%$ & $0.0 \%$ & 0.00 & $0.0 \%$ & $0.0 \%$ & 0.00 & $0.0 \%$ & $0.0 \%$ \\
\hline Ephemeroptera & & & & $0.0 \%$ & & & $0.0 \%$ & & & \\
\hline \multirow[t]{2}{*}{ Baetidae } & Accentrella & 126.10 & $3.7 \%$ & $9.0 \%$ & 0.00 & $0.0 \%$ & $0.0 \%$ & 0.00 & $0.0 \%$ & $0.0 \%$ \\
\hline & Baetis & 88.40 & $3.1 \%$ & $6.3 \%$ & 0.00 & $0.0 \%$ & $0.0 \%$ & 0.00 & $0.0 \%$ & $0.0 \%$ \\
\hline Leptophlebiidae & Paraleptophlebia & 208.00 & $7.2 \%$ & $14.9 \%$ & 0.80 & $0.0 \%$ & $0.1 \%$ & 0.00 & $0.0 \%$ & $0.0 \%$ \\
\hline \multirow[t]{2}{*}{ Ephemerellidae } & Ephemerella & 364.90 & $11.6 \%$ & $26.1 \%$ & 0.70 & $0.0 \%$ & $0.1 \%$ & 0.10 & $0.0 \%$ & $0.1 \%$ \\
\hline & unknown & 0.00 & $0.0 \%$ & $0.0 \%$ & 2.40 & $0.1 \%$ & $0.2 \%$ & 0.00 & $0.0 \%$ & $0.0 \%$ \\
\hline Ameletidae & Ameletus & 15.70 & $0.5 \%$ & $1.1 \%$ & 19.00 & $0.7 \%$ & $1.7 \%$ & 0.00 & $0.0 \%$ & $0.0 \%$ \\
\hline Tricorythidae & Tricorythodes & 0.00 & $0.0 \%$ & $0.0 \%$ & 0.10 & $0.0 \%$ & $0.0 \%$ & 0.00 & $0.0 \%$ & $0.0 \%$ \\
\hline Ephemeridae & Ephemera & 2.40 & $0.1 \%$ & $0.2 \%$ & 0.00 & $0.0 \%$ & $0.0 \%$ & 0.00 & $0.0 \%$ & $0.0 \%$ \\
\hline unknown & & 0.00 & $0.0 \%$ & $0.0 \%$ & 0.00 & $0.0 \%$ & $0.0 \%$ & 0.80 & $0.2 \%$ & $0.4 \%$ \\
\hline \multicolumn{11}{|l|}{ Trichoptera } \\
\hline \multirow[t]{5}{*}{ Hydropsychidae } & Parapsyche & 0.10 & $0.0 \%$ & $0.0 \%$ & 0.00 & $0.0 \%$ & $0.0 \%$ & 0.00 & $0.0 \%$ & $0.0 \%$ \\
\hline & Hydropsyche & 56.60 & $1.5 \%$ & $4.0 \%$ & 0.80 & $0.0 \%$ & $0.1 \%$ & 1.00 & $0.4 \%$ & $0.5 \%$ \\
\hline & Diplectrona & 105.00 & $3.5 \%$ & $7.5 \%$ & 41.40 & $2.3 \%$ & $3.7 \%$ & 0.10 & $0.0 \%$ & $0.1 \%$ \\
\hline & Cheumatopsyche & 2.10 & $0.0 \%$ & $0.2 \%$ & 3.20 & $0.5 \%$ & $0.3 \%$ & 0.10 & $0.0 \%$ & $0.1 \%$ \\
\hline & unknown & 0.10 & $0.0 \%$ & $0.0 \%$ & 0.20 & $0.0 \%$ & $0.0 \%$ & 0.00 & $0.0 \%$ & $0.0 \%$ \\
\hline Philopotamidae & Dolophilodes & 4.40 & $0.1 \%$ & $0.3 \%$ & 10.70 & $0.3 \%$ & $1.0 \%$ & 0.00 & $0.0 \%$ & $0.0 \%$ \\
\hline
\end{tabular}




\section{Appendix I. Continued}

\begin{tabular}{|c|c|c|c|c|c|c|c|c|c|c|}
\hline \multirow{2}{*}{\multicolumn{2}{|c|}{ Collectors Continued }} & \multicolumn{3}{|c|}{ Circumneutral } & \multicolumn{3}{|c|}{ Acid precipitation } & \multicolumn{3}{|c|}{ Acid mine Drainage } \\
\hline & & \multirow{3}{*}{ Average \# } & \multirow{3}{*}{$\%$ total } & \multirow[b]{2}{*}{$\%$ collectors } & \multirow[b]{2}{*}{ Average \# } & \multirow[b]{2}{*}{$\%$ total } & \multirow[b]{2}{*}{$\%$ collectors } & \multirow[b]{2}{*}{ Average \# } & \multirow{3}{*}{$\%$ total } & \multirow[b]{2}{*}{$\%$ collectors } \\
\hline & & & & & & & & & & \\
\hline \multicolumn{8}{|l|}{ Diptera } & & & \\
\hline Tipulidae & Antocha & 17.30 & $0.6 \%$ & $1.2 \%$ & 3.40 & $0.1 \%$ & $0.3 \%$ & 0.00 & $0.0 \%$ & $0.0 \%$ \\
\hline Simuliidae & Simulium & 92.80 & $3.4 \%$ & $6.6 \%$ & 599.50 & $16.6 \%$ & $54.1 \%$ & 0.00 & $0.0 \%$ & $0.0 \%$ \\
\hline Chironomidae & Non-Tanypodinae & 289.30 & $7.9 \%$ & $20.7 \%$ & 346.70 & $12.8 \%$ & $31.3 \%$ & 181.80 & $75.8 \%$ & $95.9 \%$ \\
\hline Culicidae & unknown & 0.00 & $0.0 \%$ & $0.0 \%$ & 0.00 & $0.0 \%$ & $0.0 \%$ & 2.40 & $2.4 \%$ & $1.3 \%$ \\
\hline \multicolumn{11}{|l|}{ Isotomidae } \\
\hline Poduridae & Podura & 0.80 & $0.0 \%$ & $0.1 \%$ & 0.00 & $0.0 \%$ & $0.0 \%$ & 0.00 & $0.0 \%$ & $0.0 \%$ \\
\hline unknown & & 0.80 & $0.0 \%$ & $0.1 \%$ & 4.00 & $0.4 \%$ & $0.4 \%$ & 3.20 & $5.9 \%$ & $1.7 \%$ \\
\hline
\end{tabular}

